
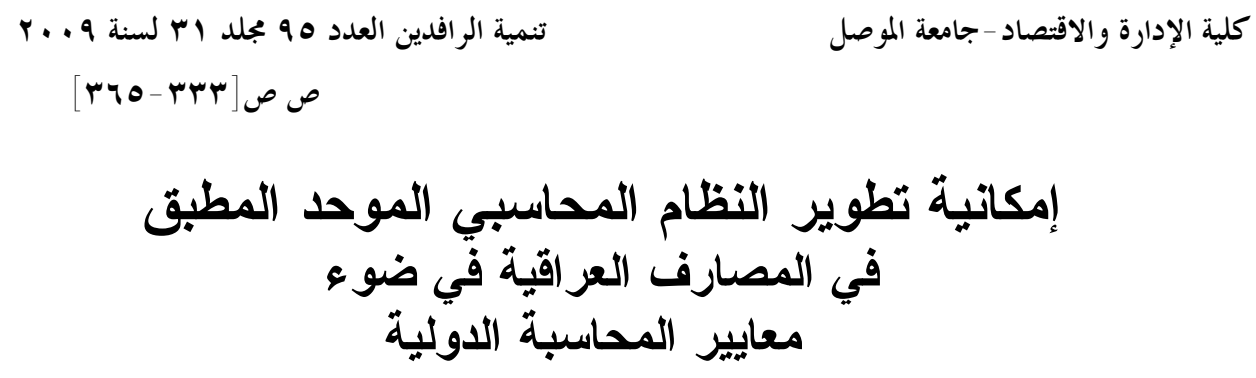

$$
\begin{aligned}
& \text { غازي عثمان محمود } \\
& \text { مدرس مساعد- قسم المحاسبة } \\
& \text { كلية الإدارة والاقتصاد-جامعة صلاح الدين }
\end{aligned}
$$

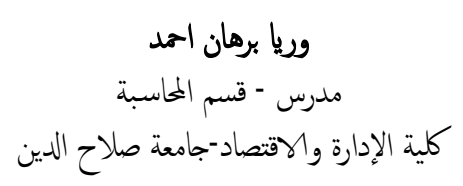

المستخلص

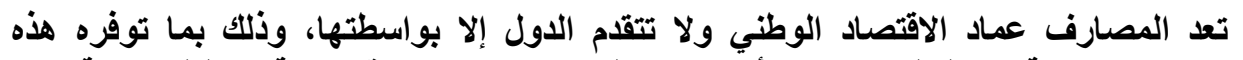

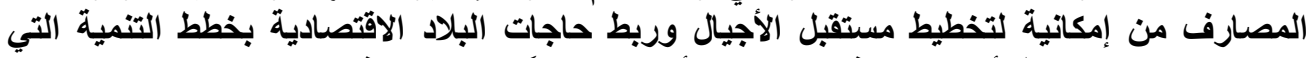

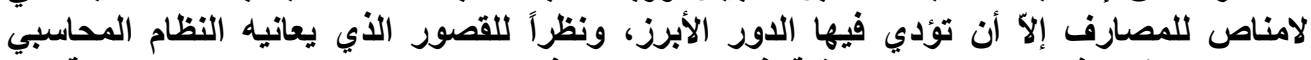

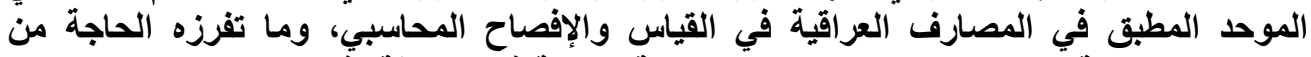

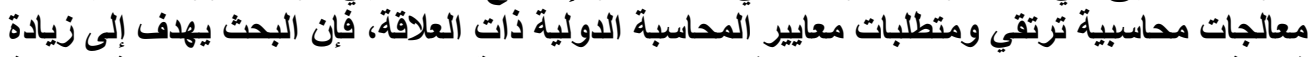

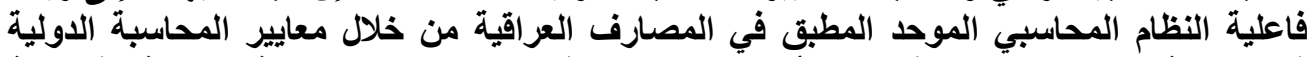

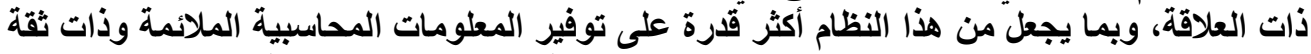

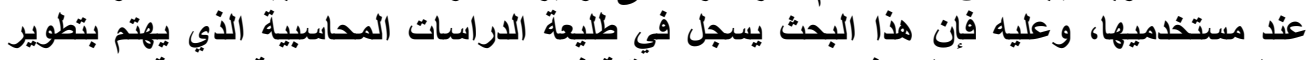

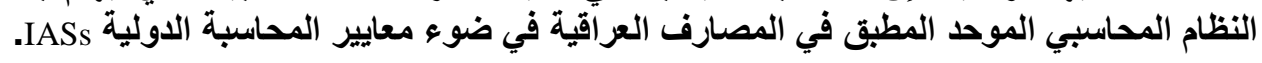

\title{
The Possibility of Developing the Unified Accounting System in Iraqi Banks in the Light of International Accounting System
}

\author{
Waria Burhan Ahmmed \\ Lecturer \\ University of Salahaddin
}

\author{
Ghazi O. Mahmood \\ Assistant Lecturer \\ University of Salahaddin
}

\section{Abstract}

Banks are considered as the main pole for national economy and without them no nation can progress, because they support planning for the future generation and link the economic needing of a country with development planning with banking play main role in it. Since, the shortage seen in the uniform accounting system in Iraqi banking in measurement and disclosure accounting. The need of appeal is from an accounting which raise with the international

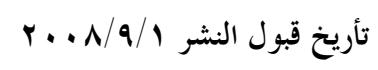

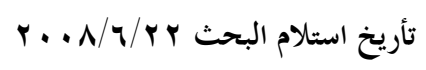




\section{أهمد ومحمود [ [بr]}

accounting standards. The research however aims to raise the progress of a uniform accounting system of Iraqi banking, through the international accounting standards that help the system to the progress more and supply more suitable relevant information on accounting for its users. The research is on of the premier studies of accounting which interest to development the uniform accounting system in Iraqi banking, through the international accounting standards.

يتفق الباحثون و التظظيمات المهتمة بالنشاط المصرفي على أن القطاع المصرفي

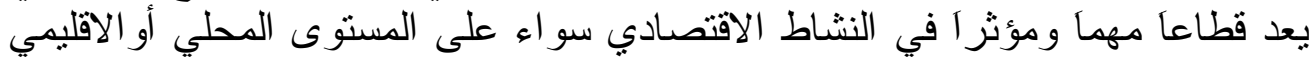

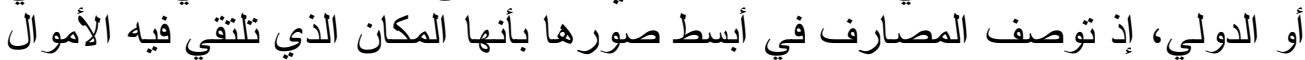

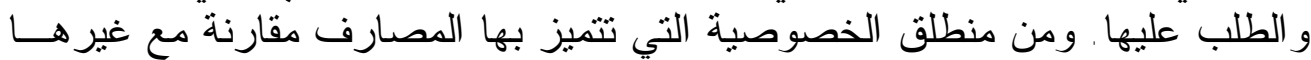

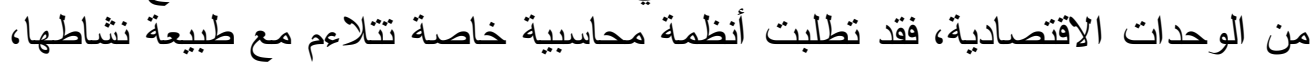

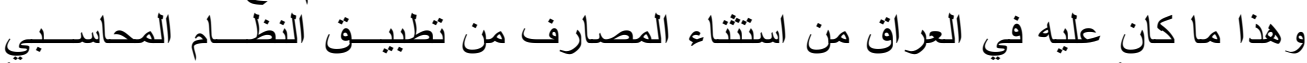

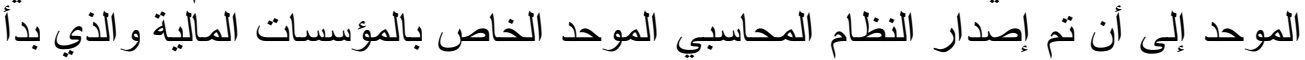

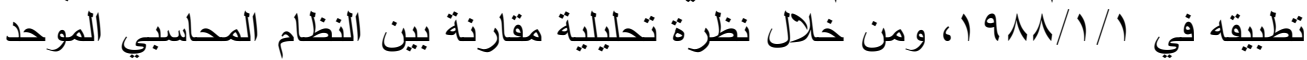

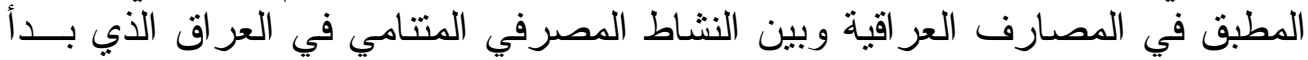

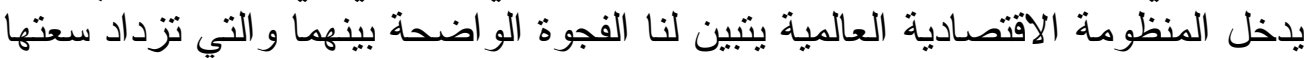

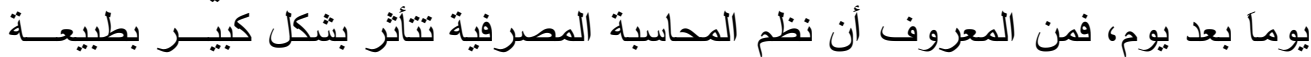

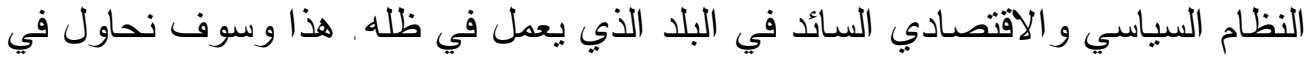

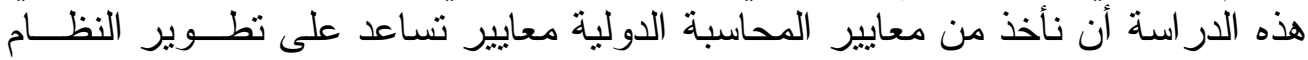

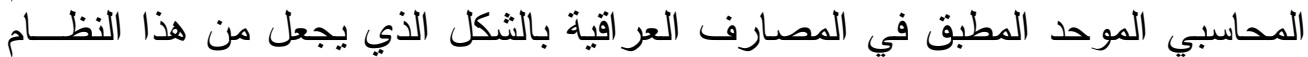

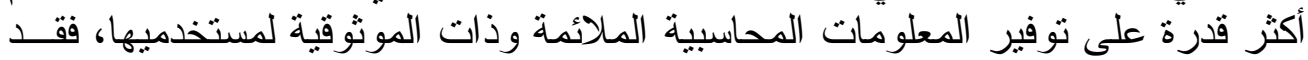

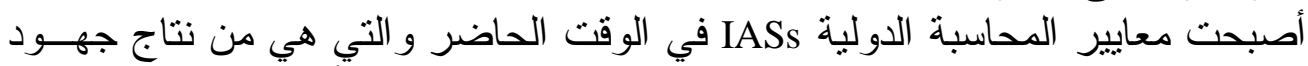

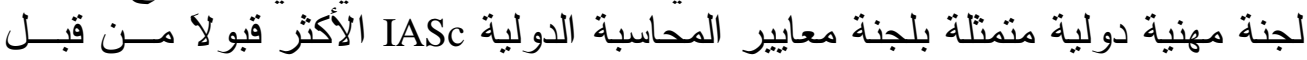

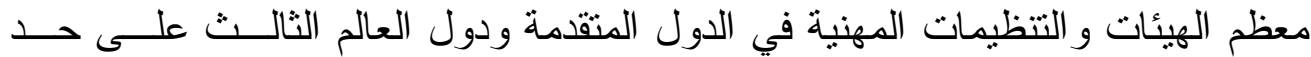

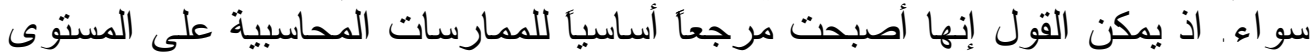

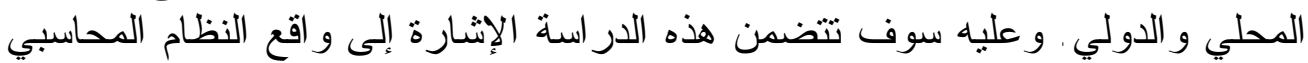

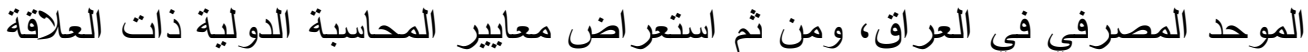

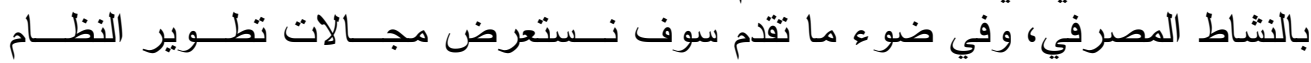
المحاسبي الموحد المطبق في المصارف العر اقية وفقاً لمعايير المحاسبة الدولية. 


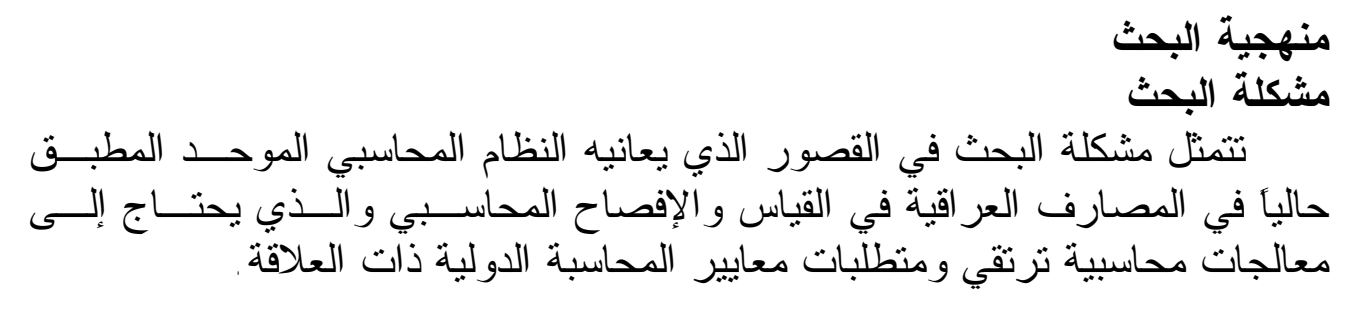

هدف البحث

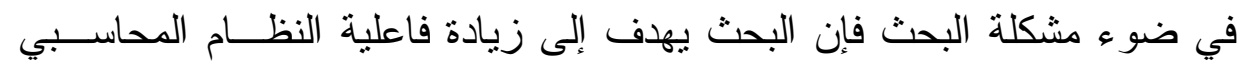

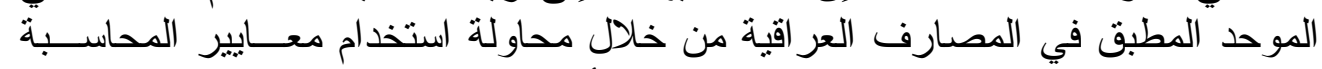

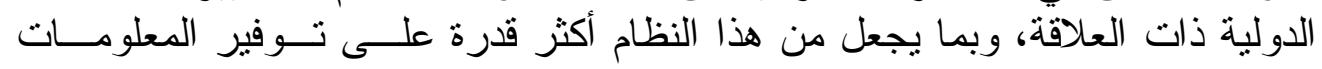
المحاسبية الملائمة وذات موثوقية وبهات لمستخدميها.

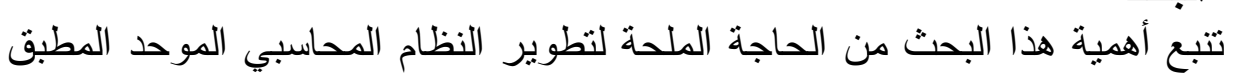

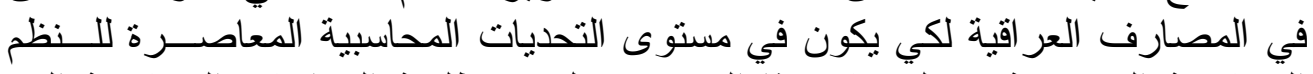

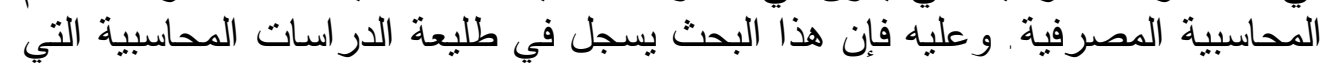

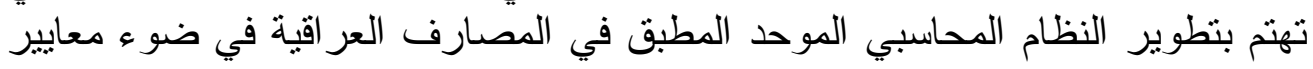
المحاسبة الدولية IASs.

إن محاولة تبني معايير المحاسبة الدولية ذات العلاقة بالقياس و الإفصاح المحاسبي

فرضية البحث

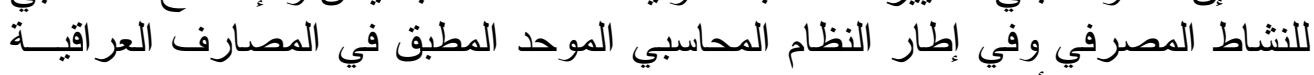

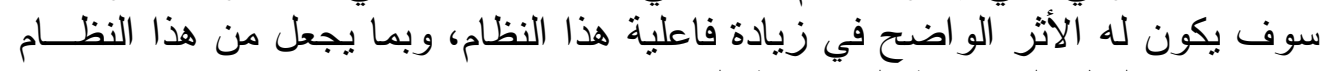

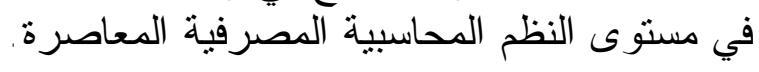

وصو لا لتحقيق هدف البحث و أهميته وفرضيته فقد تم تقسيمه علــى الفقــر ات

خطة البحث الآتية:

أولا: : و اقع النظام المحاسبي الموحد المصرفي في العراق .

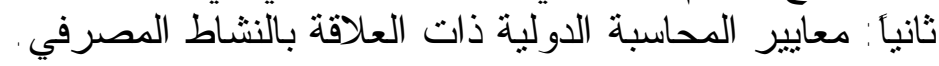

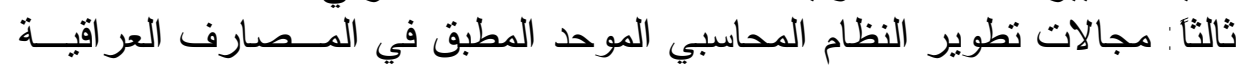

وفقا لمعايير المحاسبة الدولية. 
أهمد وحمود [4rr]

أولاً - واقع النظام المحاسبي الموحد المصرفي في العراق

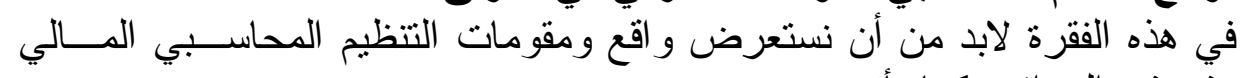

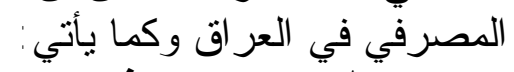

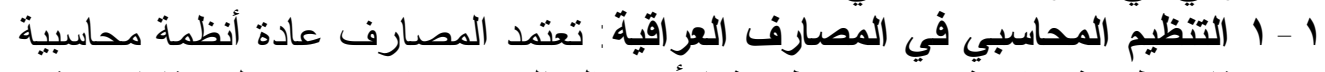

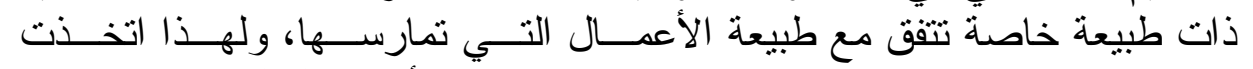

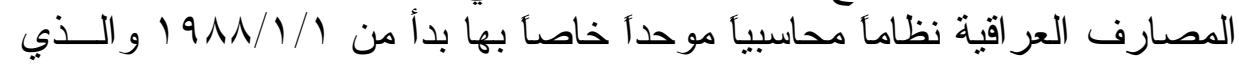

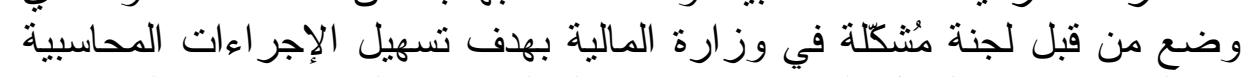

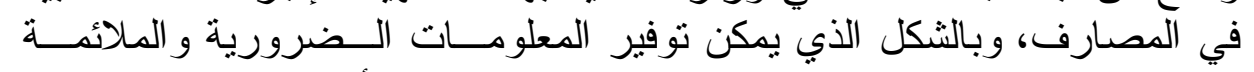

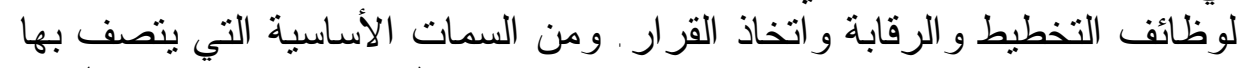

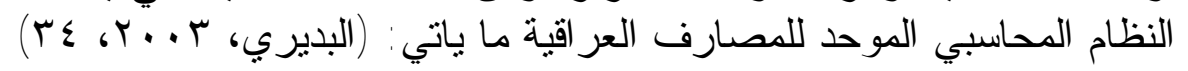

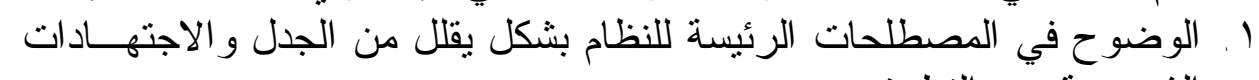

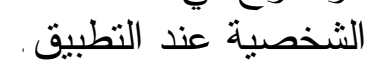

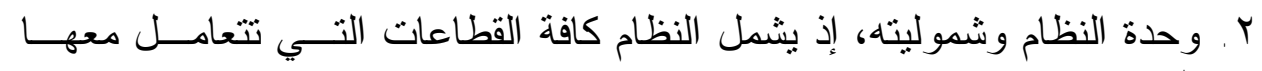

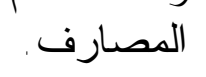
r. البساطة و المرونة في التطبيق.

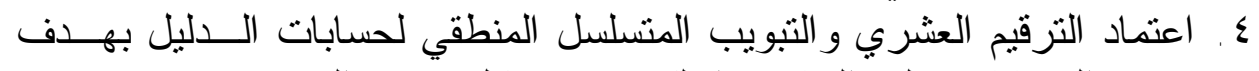

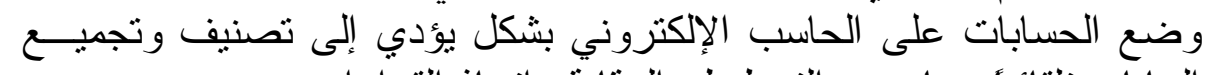

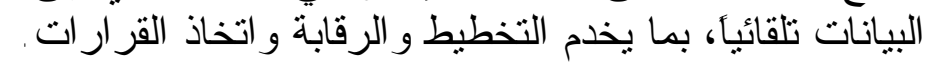

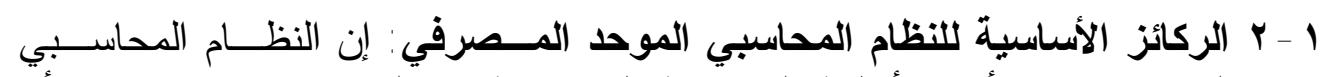

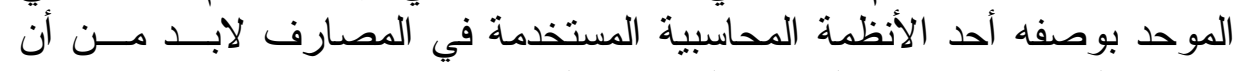

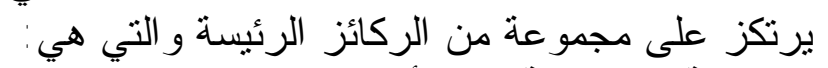

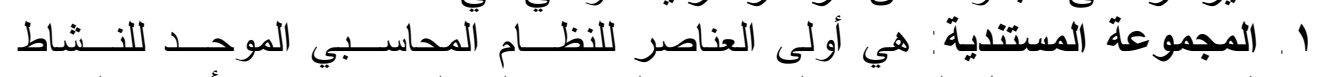

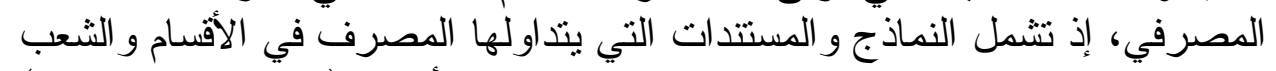

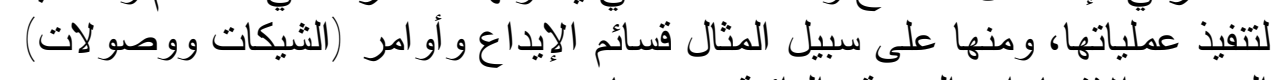
السحب و الإثعار ات المدينة و الدائنة و وغير ها.

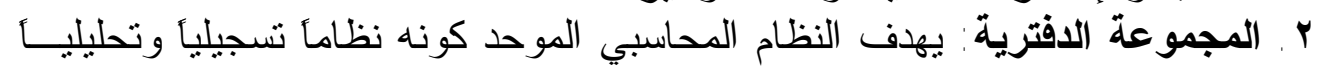

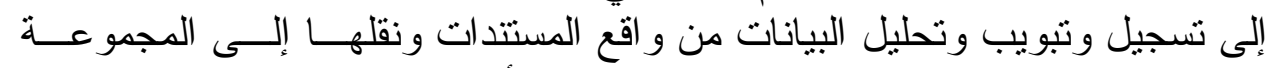

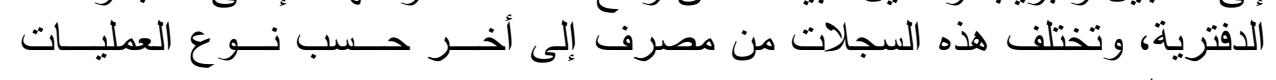
وحجمها.

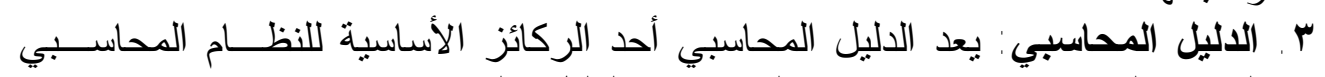

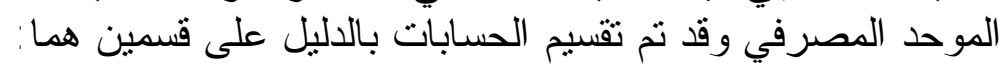


• حسابات المركز المالي: تهدف إلى تصوير المركز المالي للمصرف في نهايــة

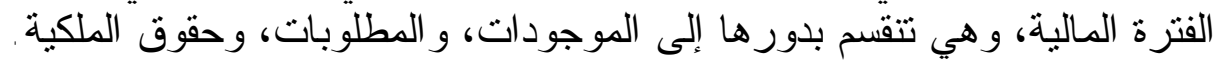

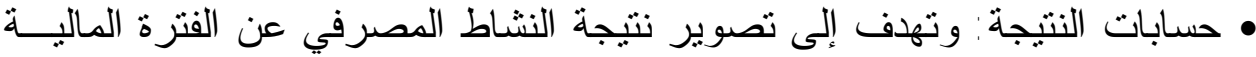

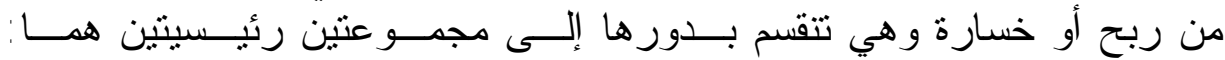

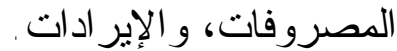

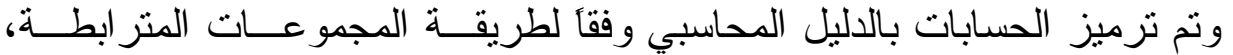

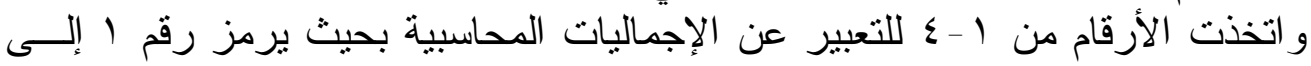

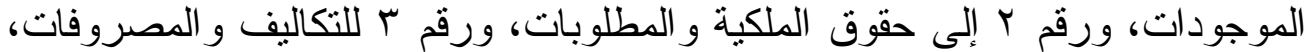

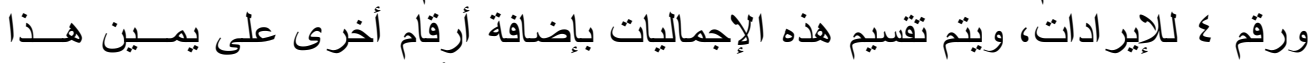

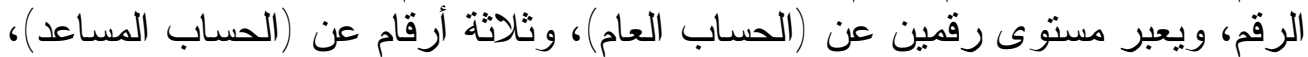

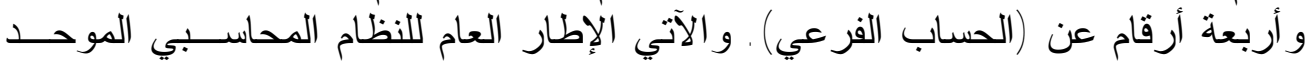

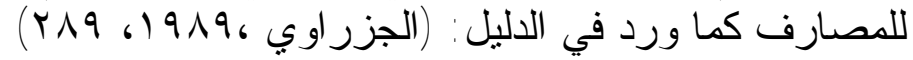

\begin{tabular}{|c|c|c|c|}
\hline \multicolumn{2}{|c|}{ حسابات النتيجة } & \multicolumn{2}{|c|}{ حسابات المركز المالي } \\
\hline ( ) الإير ادات & (r التكاليف و المصروفات & (r)حقوق الملكية و المطلوبات & ( 1 ) الموجودات \\
\hline 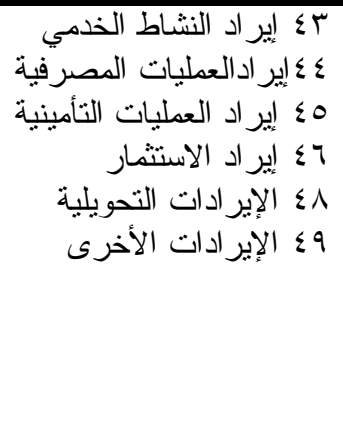 & 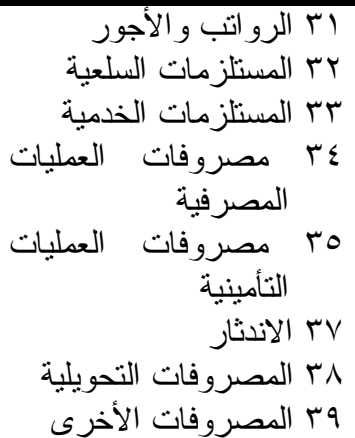 & 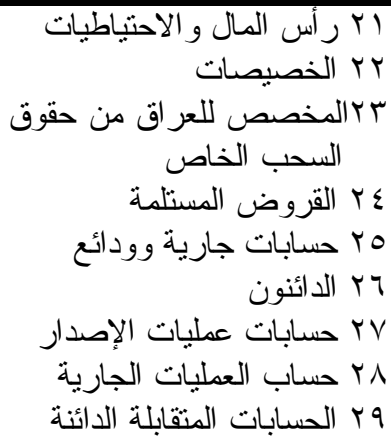 & 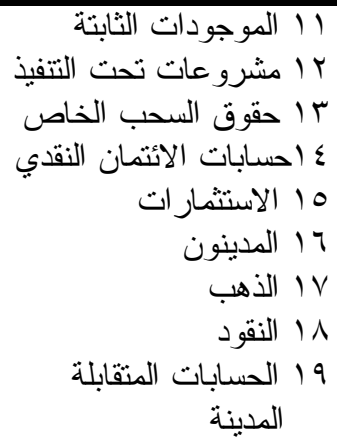 \\
\hline
\end{tabular}

هذا وقد اتسم الدليل المحاسبي بالمرونة في التطبيق، بهدف تمكين المصارف من

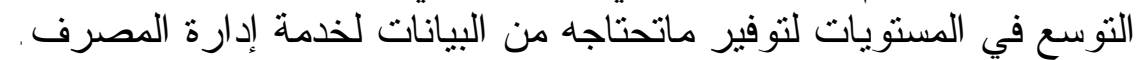

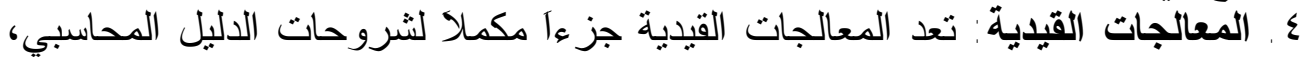

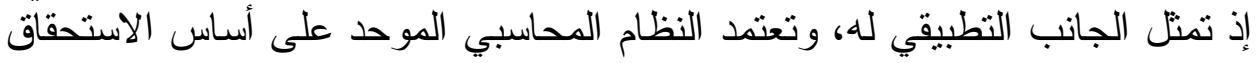
في إثبات قيود العمليات المالية التي تحدث في الوحدة الاقتصادية وخاصة في نهاية السنة المالية.

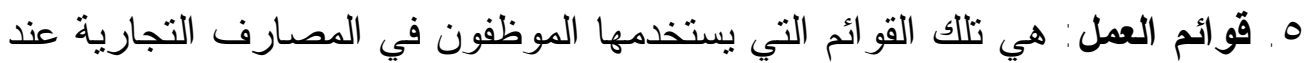
تطبيق أي نظام محاسبي كمسودات قبل القيام بإجر اء قيود معقدة تستدعي عمليـات فئات حسابية كثيرة، أو قبل إعداد التقارير ومثنالها: 
أحمد ومحمود [r/r]

• ميز ان المر اجعة للتأكد من أن قاعدة القبد المزدوج تم إتباعها لتسجيل الأحداث • • قائمة عمل لتعديل ميز ان المر اجعة.

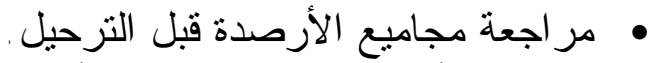

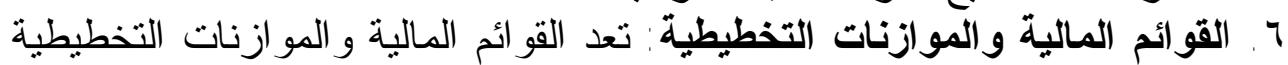

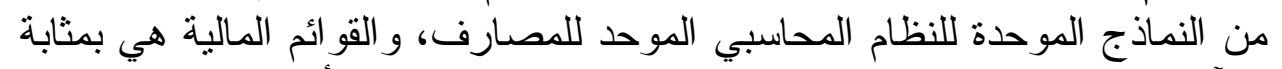

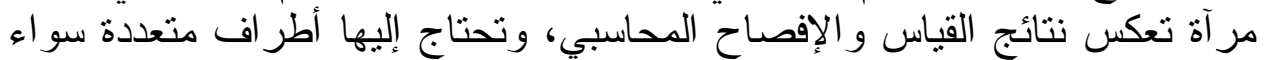

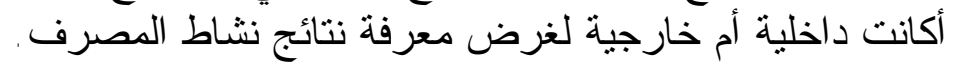

ثانياً - معايير المحاسبة الدولية ذات العلاقة بالنشاط المصرفي: نتناول في هذا المحور

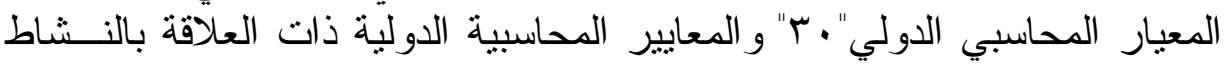

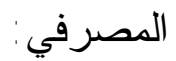

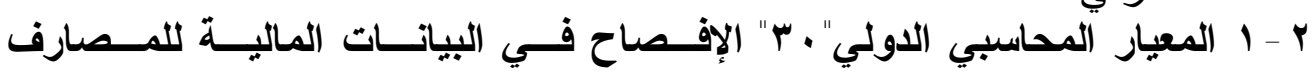

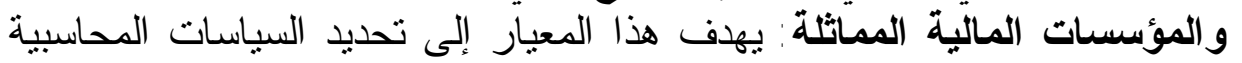

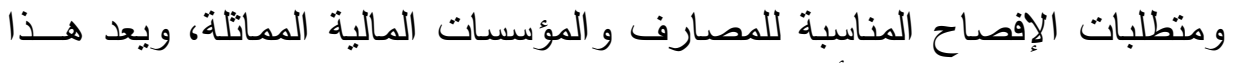

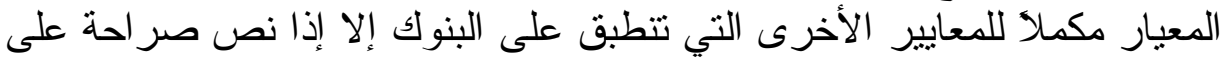

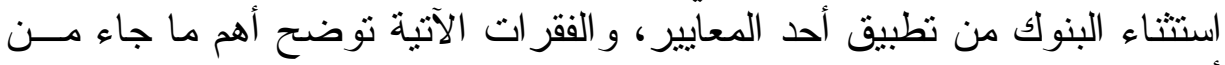
أساسيات في هذا المعيار :

• مجالات تطبيق المعيار : (IFRSs, 2004, P1154)

1 ـ يجب تطبيق هذا المعيار عند إعداد البيانات المالية للبنــوك و المؤســــات الماليـــة المماتلة .

r . لأغر اض تطبيق هذا المعيار ، يستخدم لفظ "بنك" ويعني كافة المؤسسات المالية التي

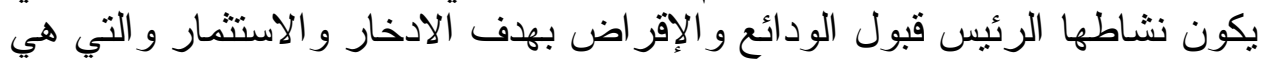

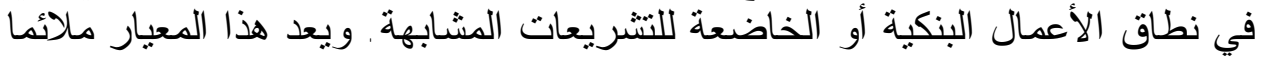

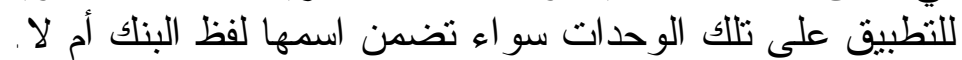

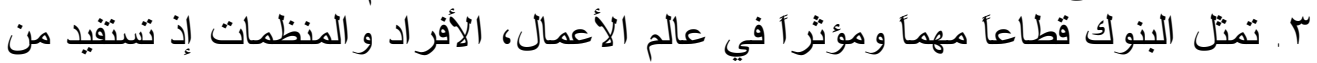

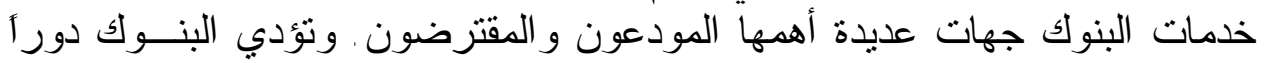

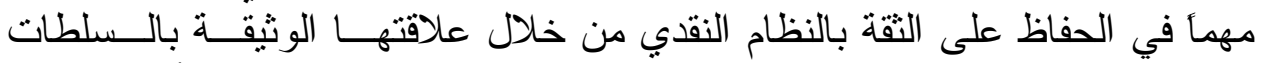

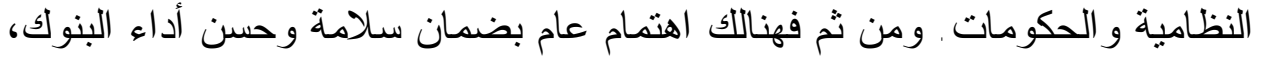

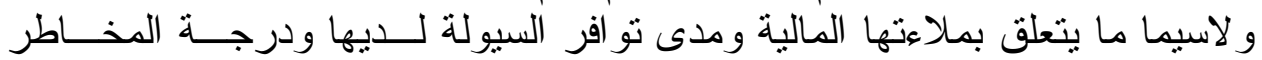

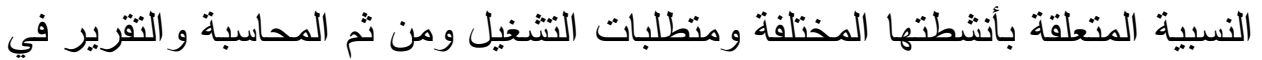

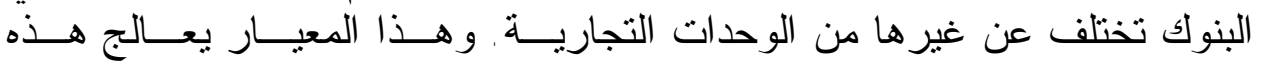


الاحتياجات الخاصة ، كما يشجع عرض الملاحظات و الإيضاحات المتعلقة بــبعض

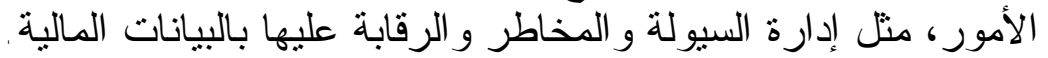

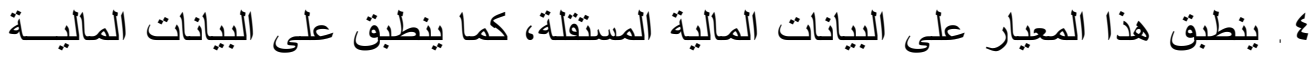

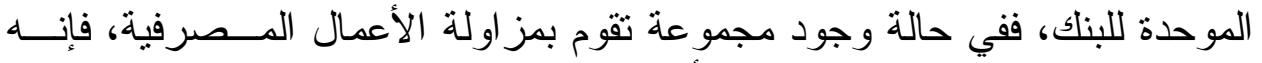

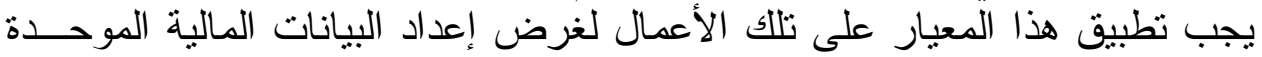

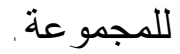
و أهم المجالات التي عالجها هذا المعيار :

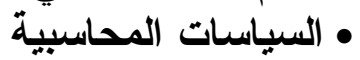

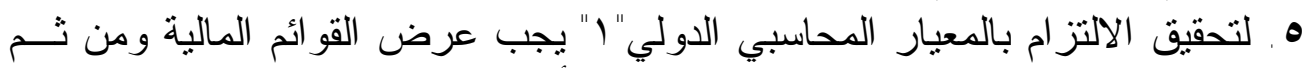

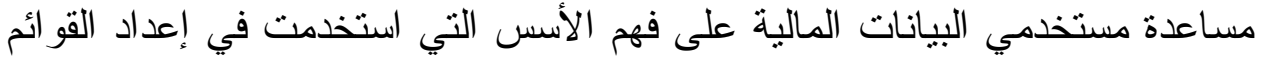

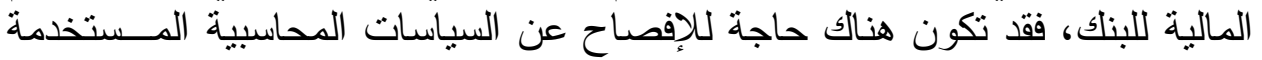

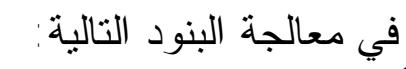
أ. ت تحقق الإير ادات الرئيسة. ب. بقتييم الاستثمار ات و الأور اق الماتية المالية لغرض الاتجار

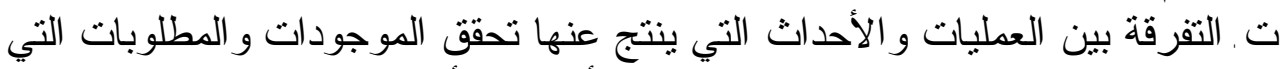

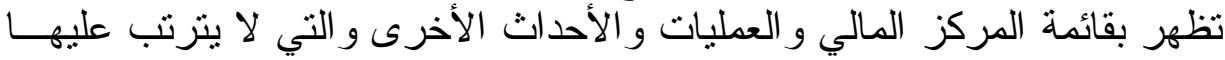
سوى مطلوبات احتمالية وتعهدات.

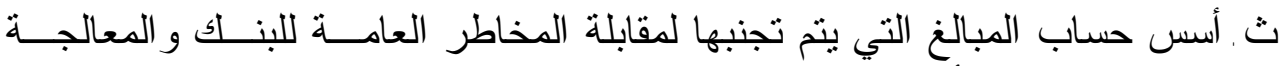
المحاسبية لتلك الأعباء.

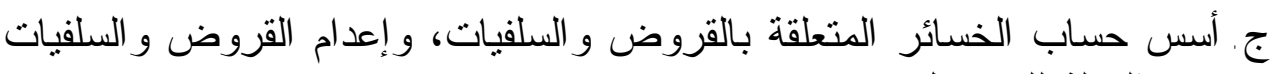
غير القابلة للنحصيل.

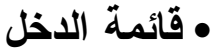

7 . . على البنكا أن يعد قائمة دخل و أن يتم تبويب الإير ادات و المصروفات في مجمو عات

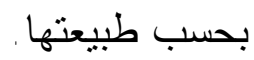
V . الإفصاح بالقائمة عن مقدار كل بند من بنود الإير ادات و المصروفات الرئيسة.

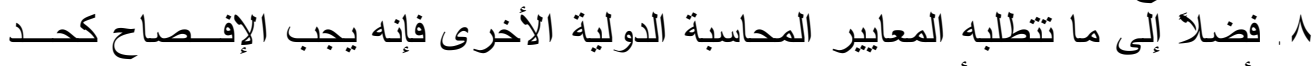

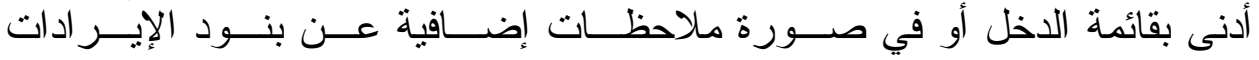

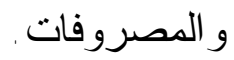
9 ـ ـتثمل البنود الرئيسة لإير ادات البنك من النشاط على الفوائــد، رســوم الخــدمات

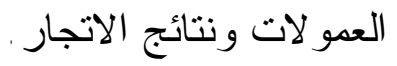
• 1. الإفصاح بشكل مستقل عن كل نو لإت عن من هذه الإير ادات، وذلك لمساعدة مستخدمي

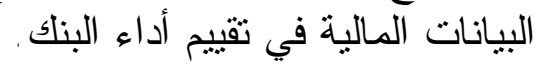




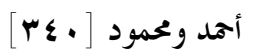

111 ـ تشمل البنود الرئيسة لمصروفات البنك الناتجة عن النشاط على الفو ائد، العمو لات،

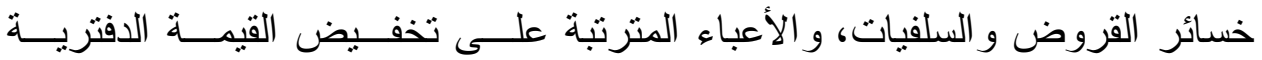

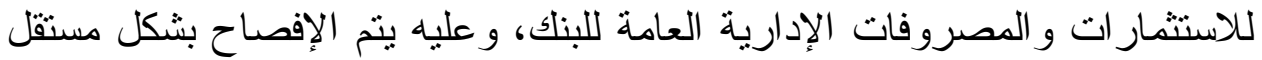

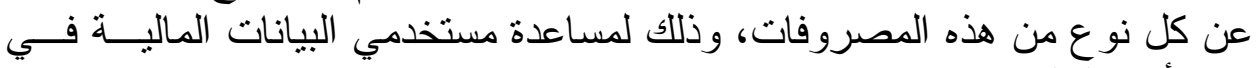
تقبيم أداء البنك من هن

rا ـ يجب عدم إجر اء مقاصة بين بنود الإير ادات وبنود المصروفات، ويـستثىى مـن ذلك :

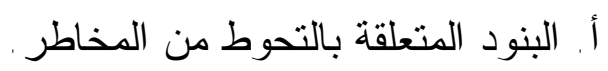

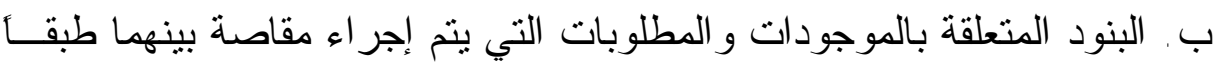

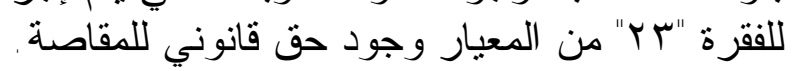

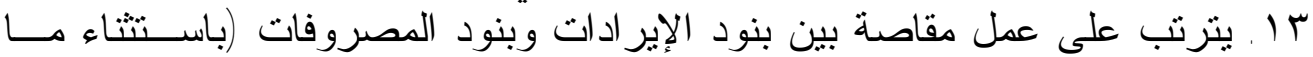

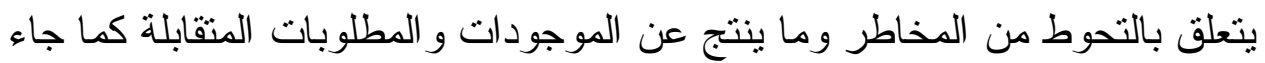

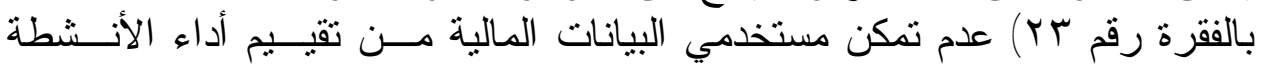

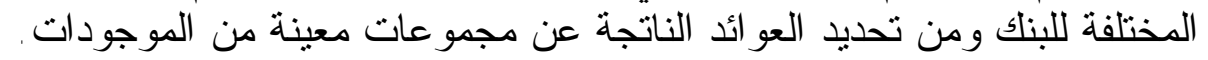

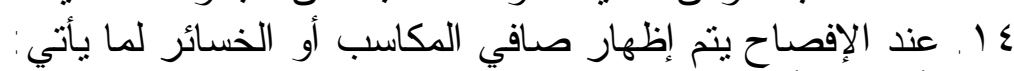

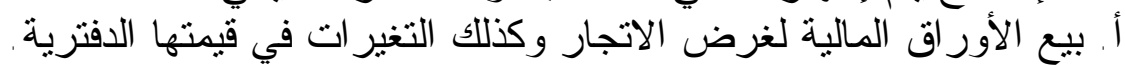

$$
\text { ب. ب. بيع الاستثمار في العملات في أور القبن مالية. }
$$

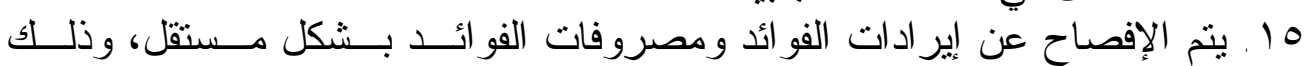

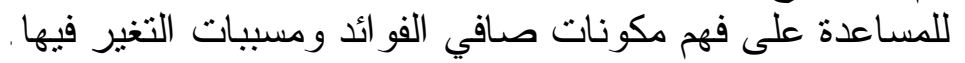

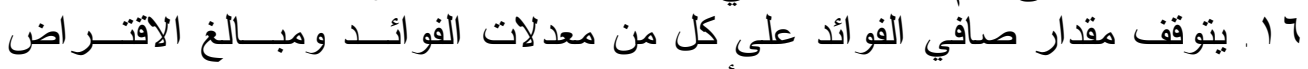

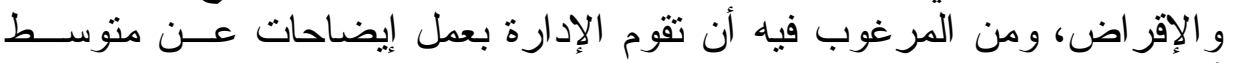

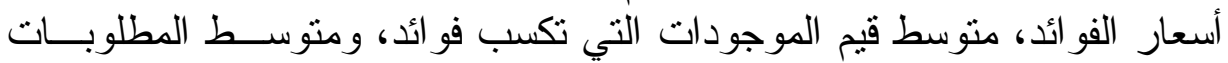

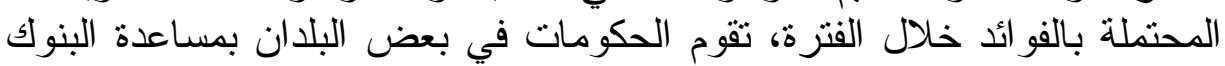

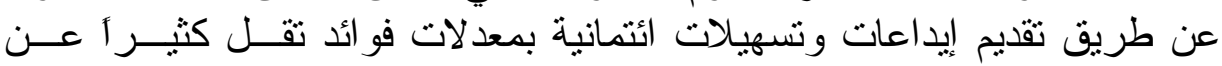

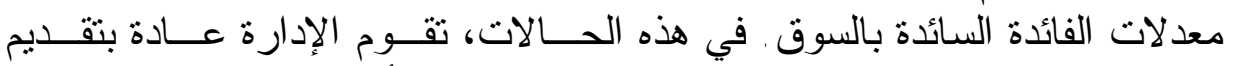

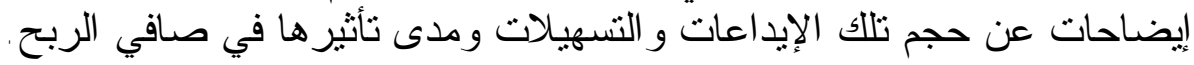

(IFRSs, 2004, 1157)

• (الميز انية البة

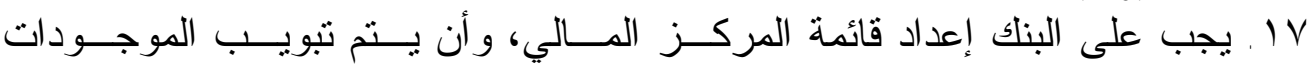

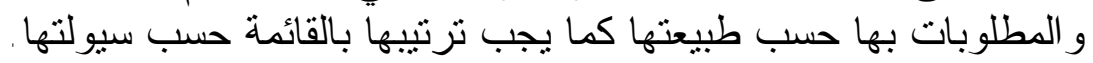




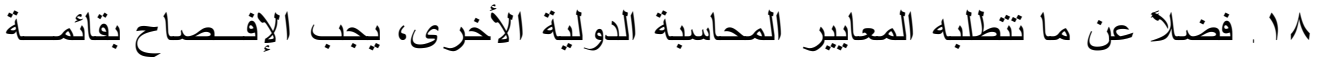

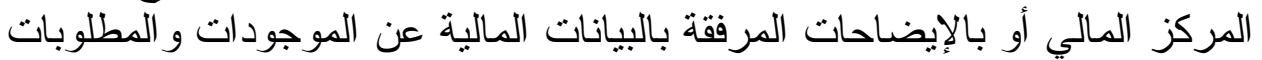

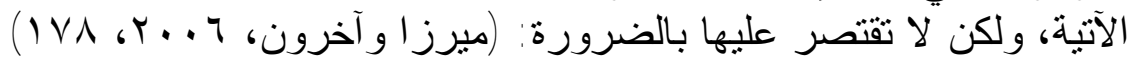

أ. النقد و الأرصدة لدى البنك المركزي.

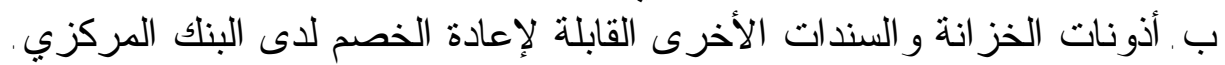

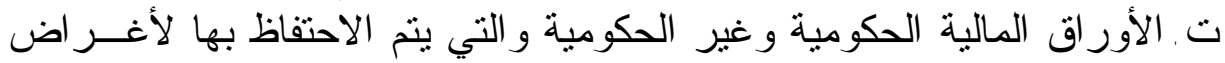

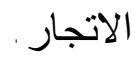

ث. الموجودات المودعة لدى البنوك الأخرى و القروض و السلف المقدمة لها. ج. الاستثمار ات في الأور اق المالية و الاسوق الأروق المالية.

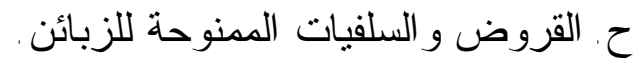
أ. أ. ودائع من البنوك الأخرى.

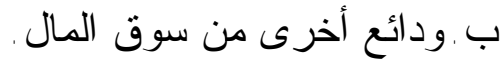

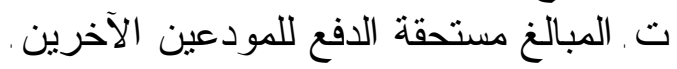

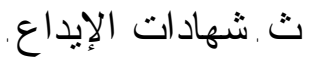
ج. السندات و الالنز امات الأخرى المنثبتة بالأور اق .

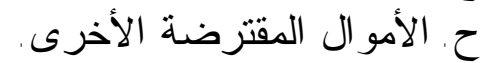

9 1. يستفاد من الفصل بين الأرصدة مع البنوك الأخرى و الأرصدة الناتجة عن التعامل

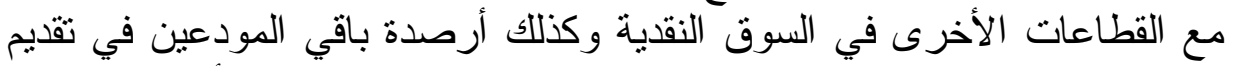

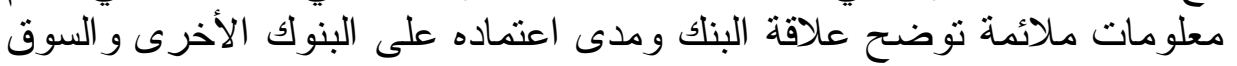

النقاية. ولذا يفصح البنك عما يأتي: (IFRSs, 2004, 1157-1158)

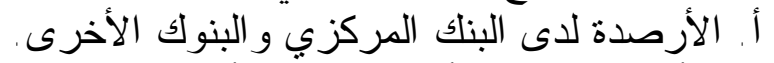

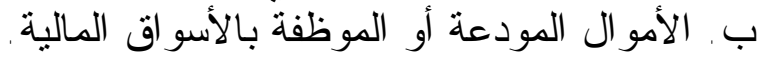

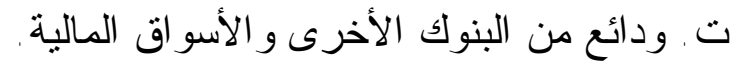

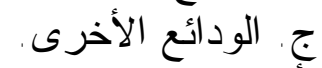

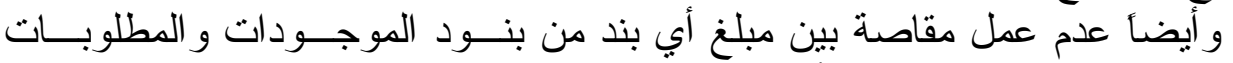

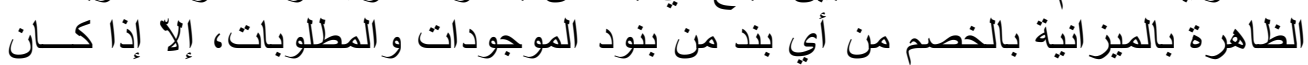

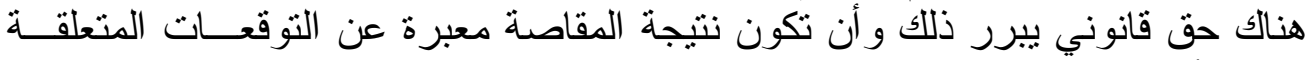

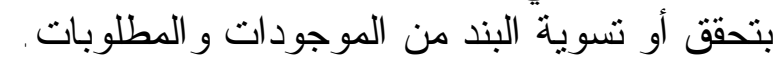

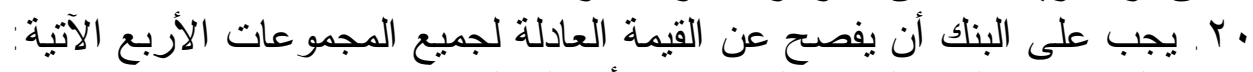
م القروض و الذمم الدينة النانئئة عن أعماله المعتادة. 
أهمد وحمود [rك

$$
\begin{aligned}
& \text { م الاستثمار ات المحتفظ بها لتاريخ الاستحقاق . }
\end{aligned}
$$

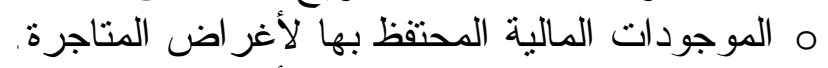

$$
\begin{aligned}
& \text { م الموجودات المالية المحتفظ بها لأغر اض الاض البيع. }
\end{aligned}
$$

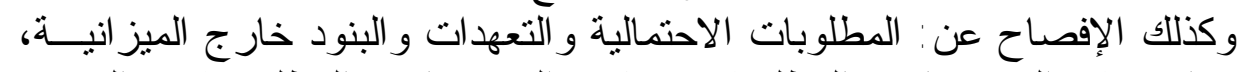

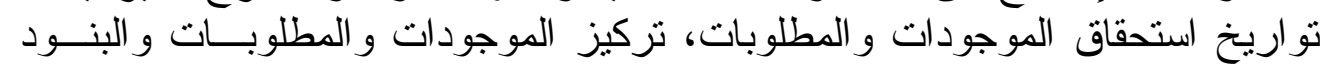

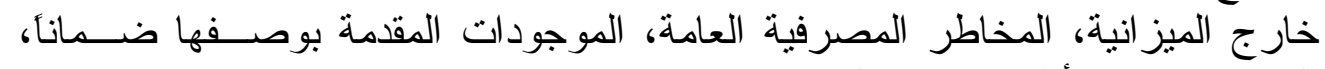

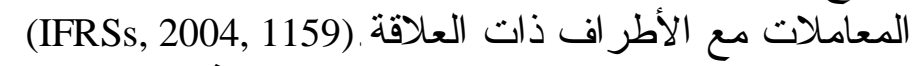

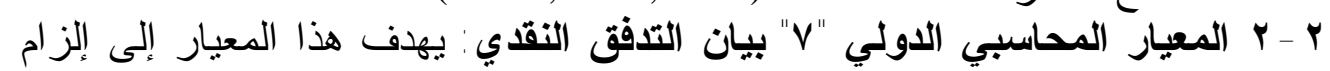

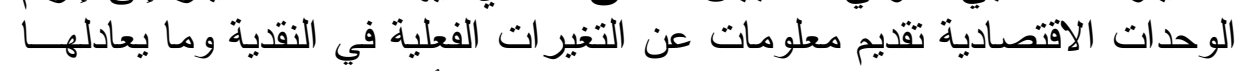

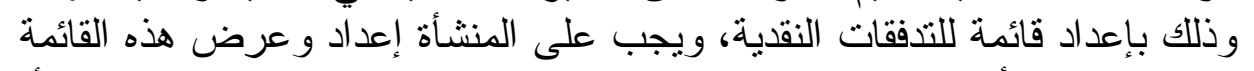

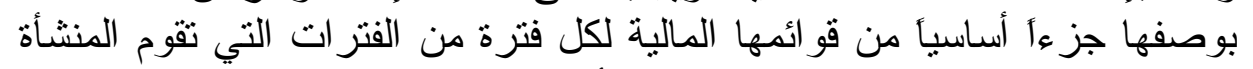

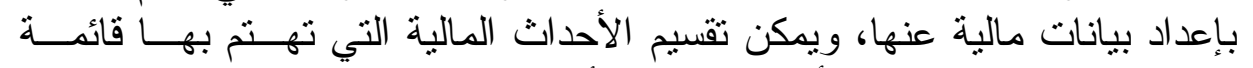

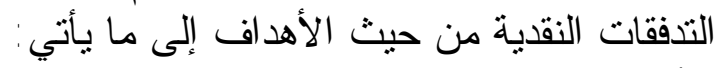

أ. أحداث تمويلية (Cash Flow From Financing Activities)

ب. بأحداث رأسمالية (Cash Flow From Investing Activities)

ت. أحداث تشغيلية (Cash Flow From Operation Activities)

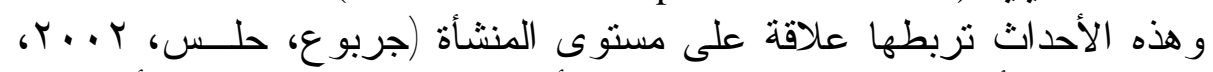

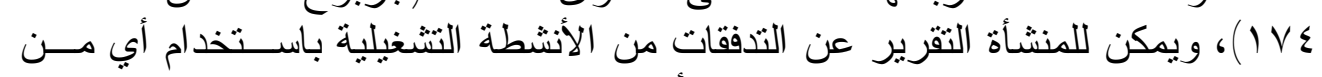

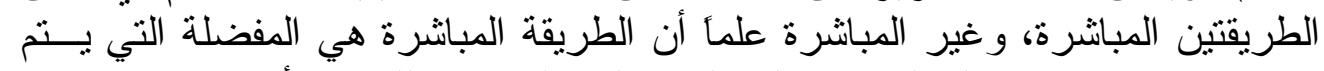

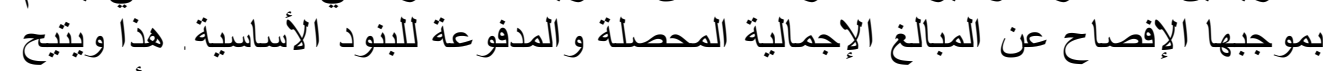

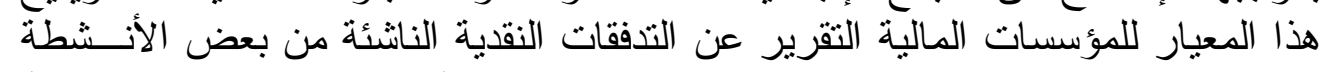

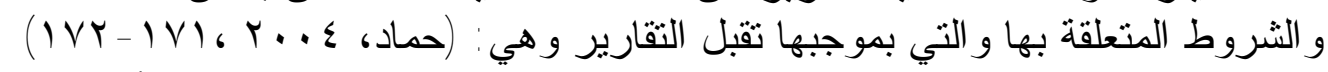

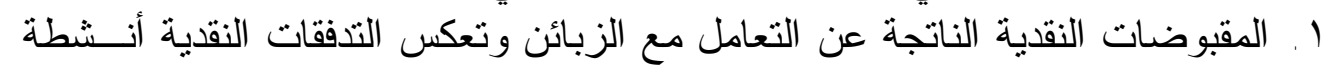

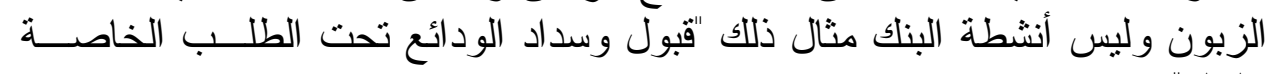

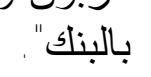

r . . المقبوضات و المدفو عات النقدية لقبول و إعادة سداد الودائع ذات تــاريخ اســتحقاق ثابت.

r. المقاصة بين الإيداعات و المسحوبات منها الناتجة من التعامل مع المؤسسات المالية

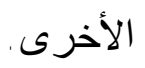

ع . السلفيات و القروض النقدية لزبائن البنك و إعادة سدادها.

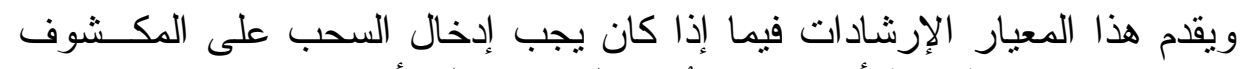

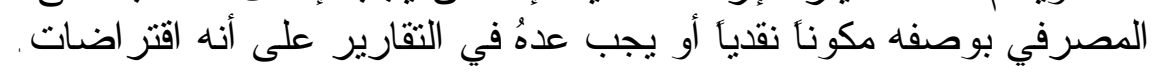


r - r المعيار المحاسبي الدولي رقم "§ ب" الإفصاح عن الأطراف ذات العلاقة: العهف

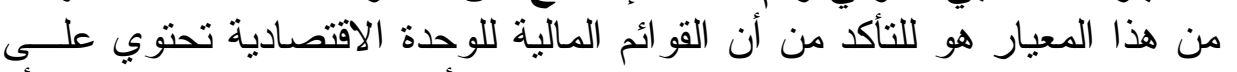

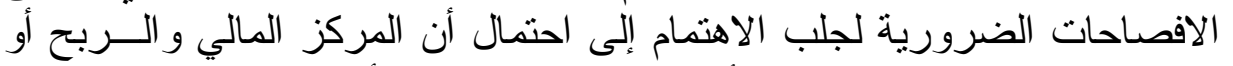

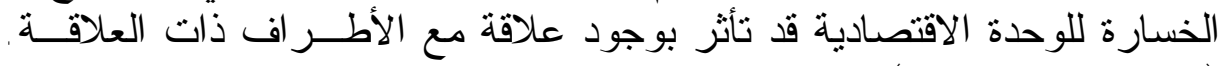

(IFRSs, 2004, 1066)

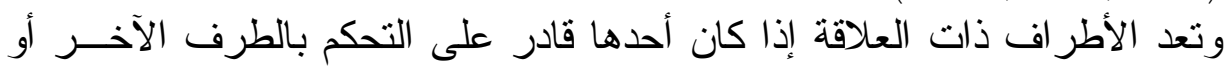

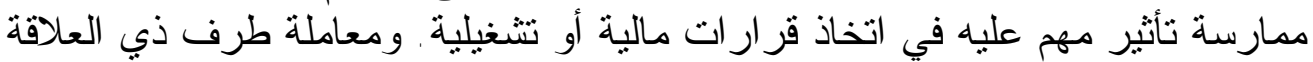

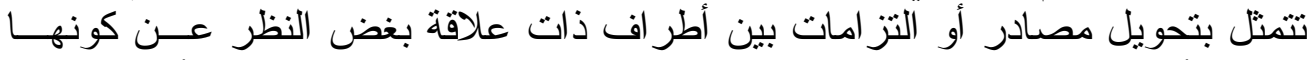

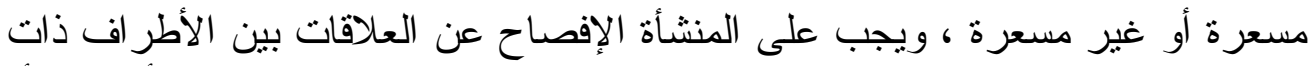

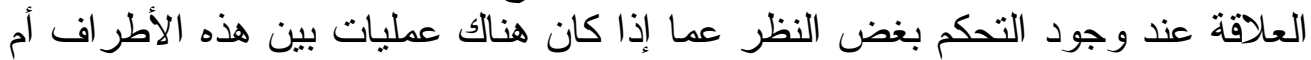

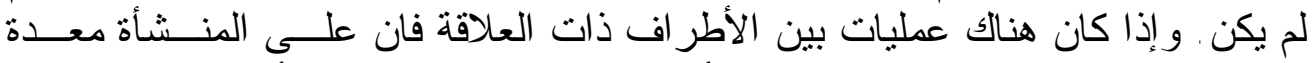

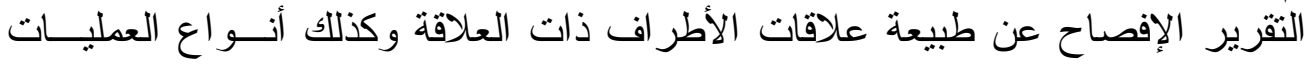

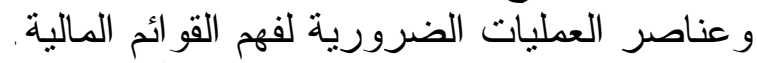

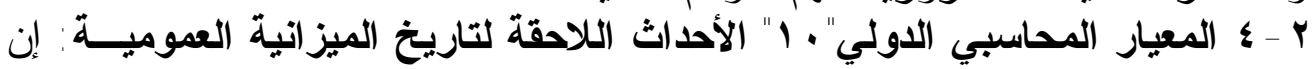
الهدف من هذا المعيار هو وصفي: (IFRSs, 2004, 691) ا ـ متى يجب على الوحدة الاقتصادية تعديل قو ائمها المالية للأحداث اللاحقة لتأريخ

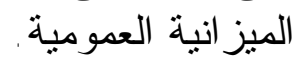

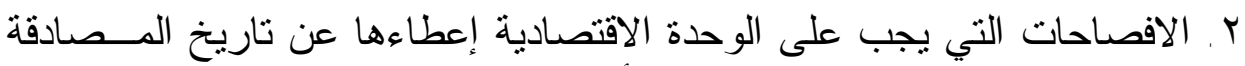

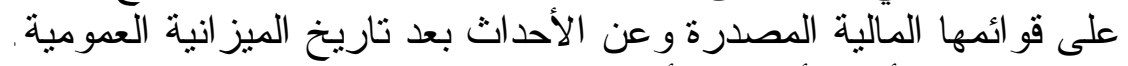

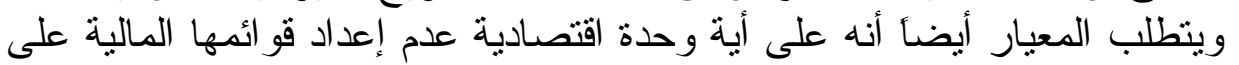

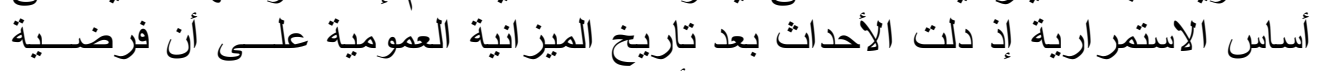

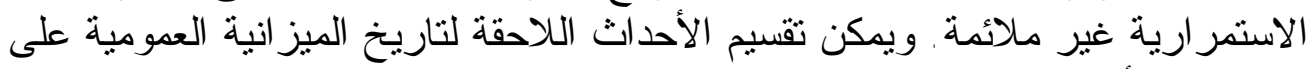

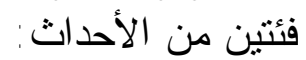

• أحداث لاحقة توفر إثباتات إضافية حول أمور كانت قائمة بتــاريخ الميز انيــة

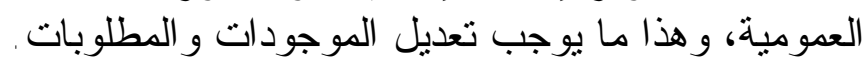

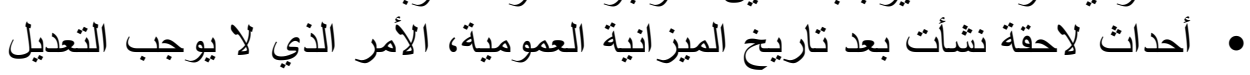

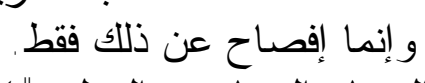

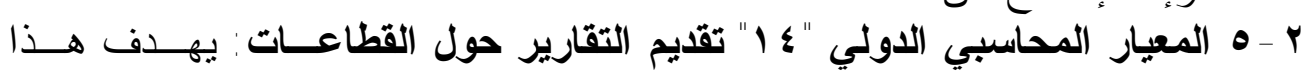

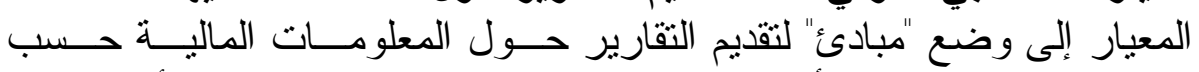

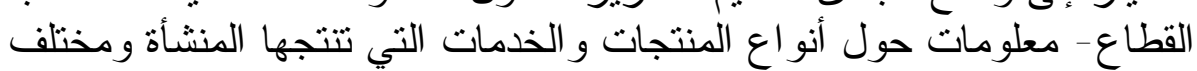

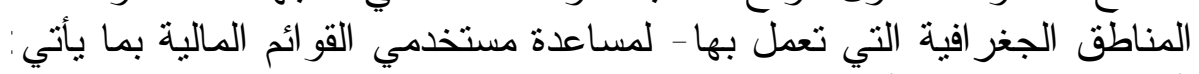

(IFRSs, 2004, 787) أ. فهم أفضل للأداء السابق للوحدة الاقتصادية. 
أحمد ومحمود [ع «r]

ب . تقييم أفضل لمخاطر و وعو ائد الوحدة.

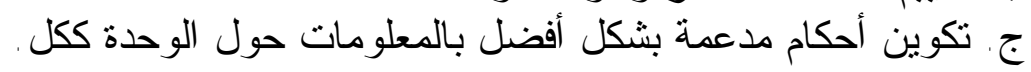

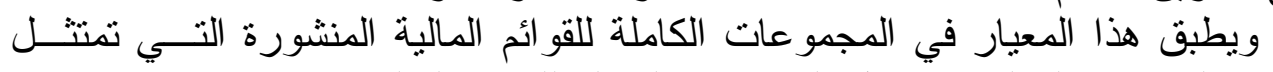

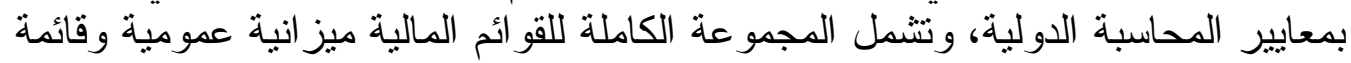

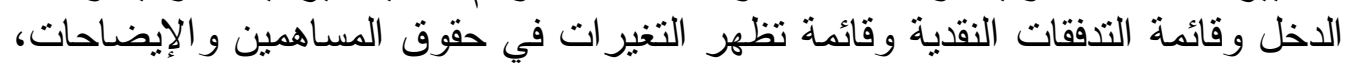

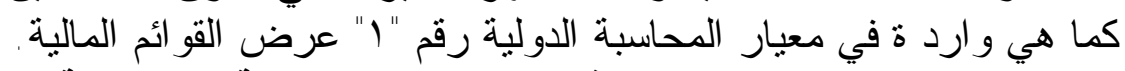

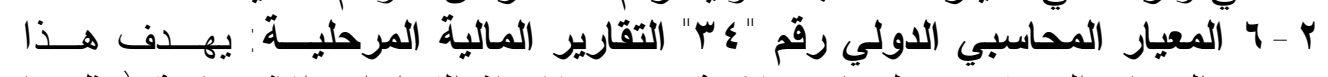

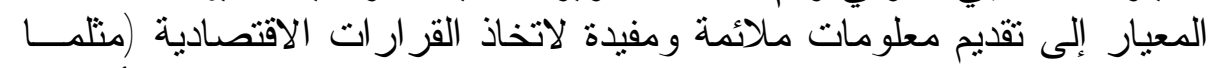

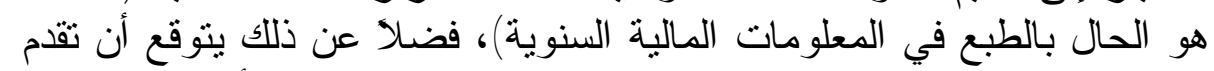

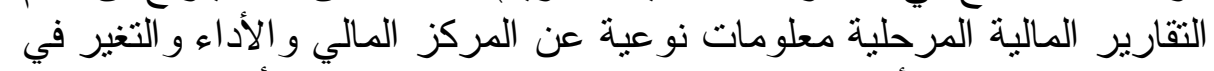

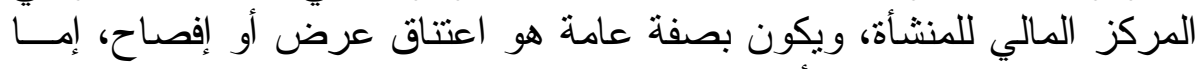

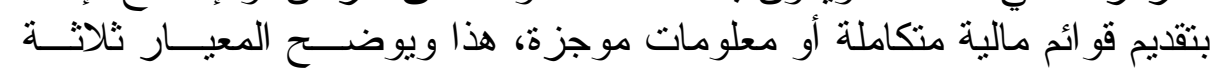

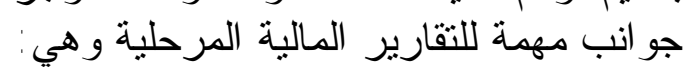

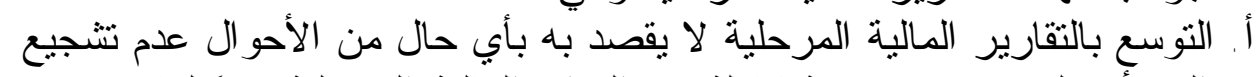

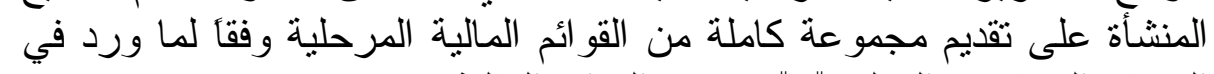

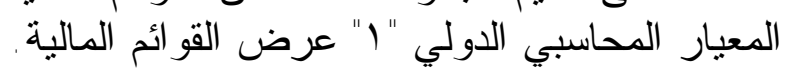

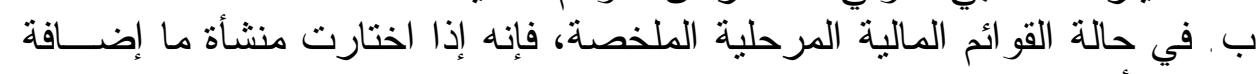

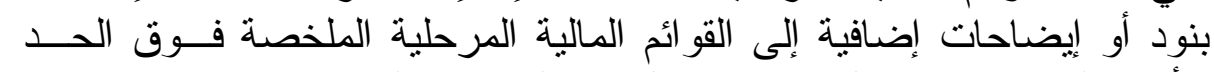

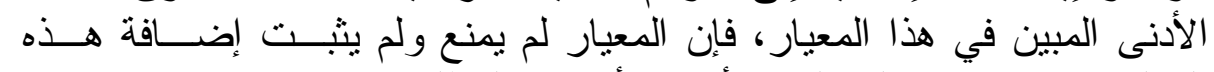

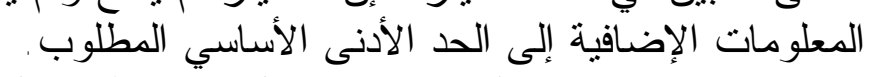

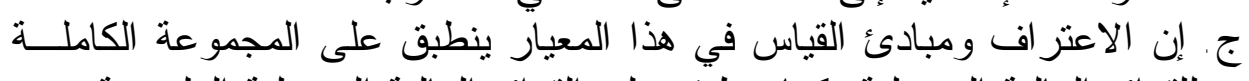

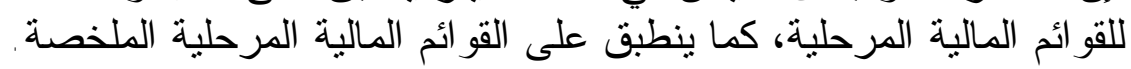

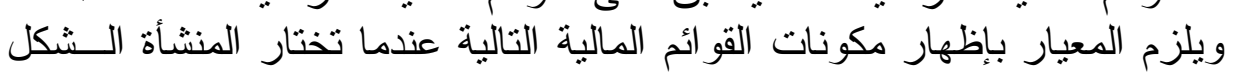

$$
\text { ○ } 0
$$

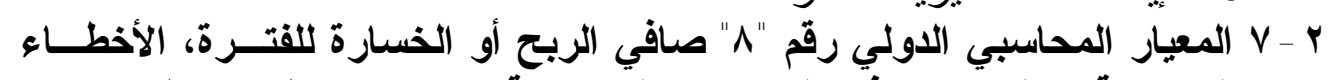

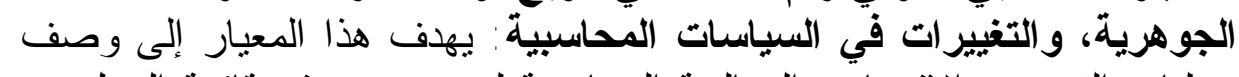

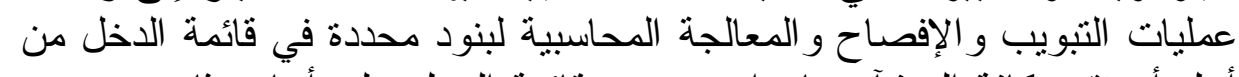

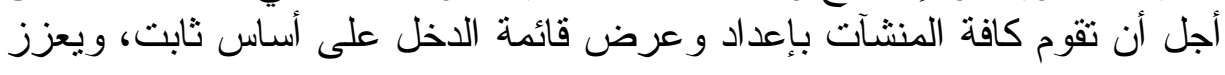


هذا القابلية للمقارنة مع القو ائم المالية للمنشآت لفتر ات سابقة ومع القو ائم الماليـــة

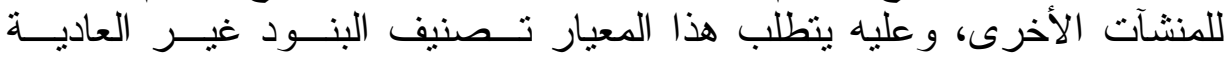

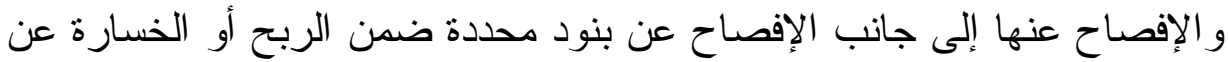

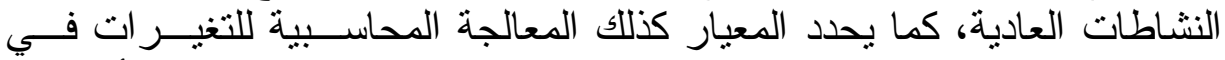

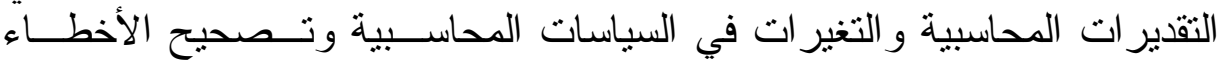

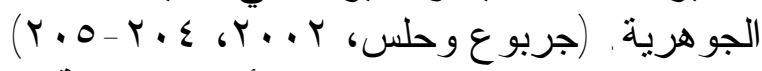

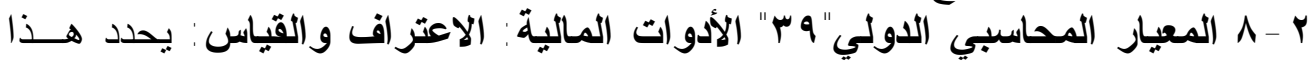

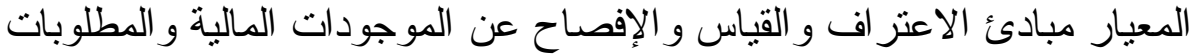

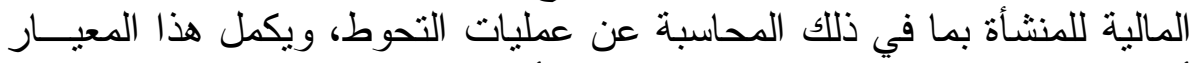

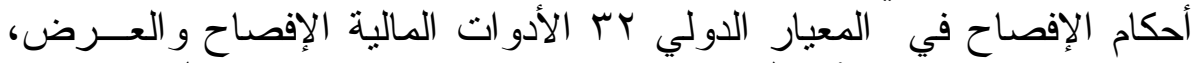

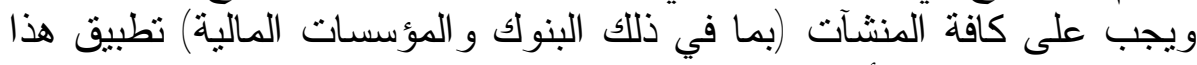
المعيار على جميع الأدوات المالية. الماتية.

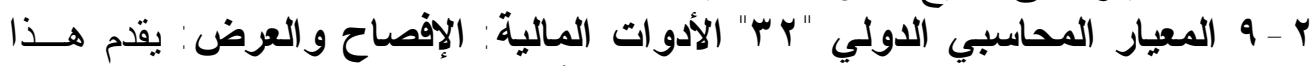

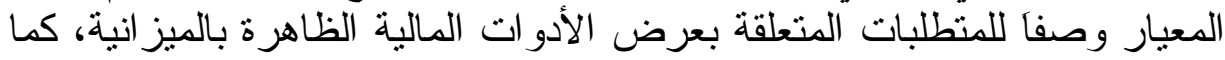

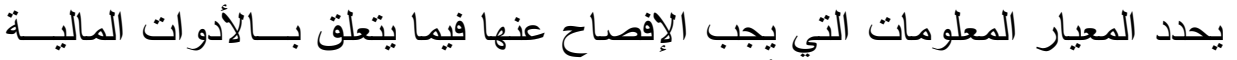

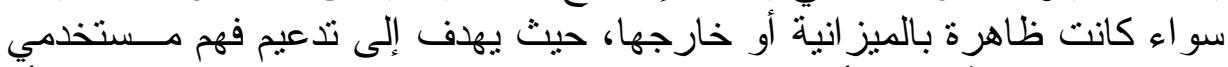

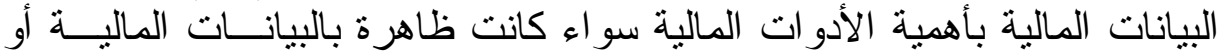

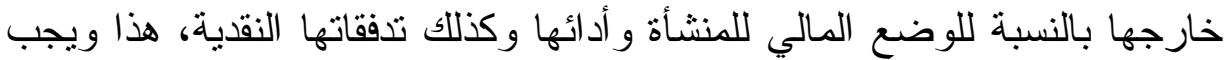

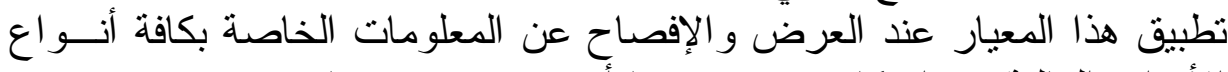

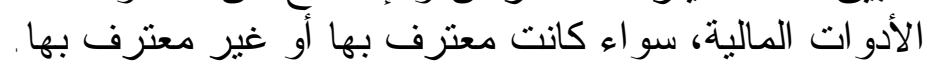

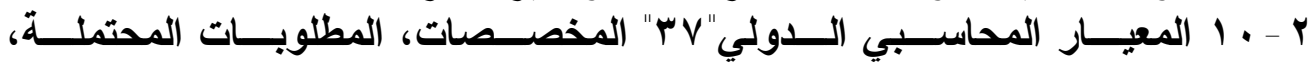

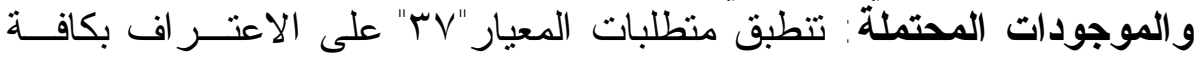

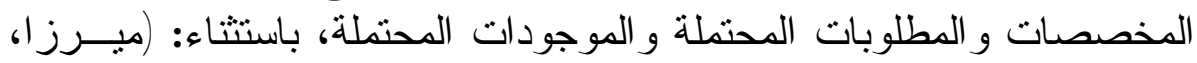

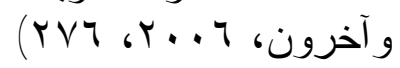

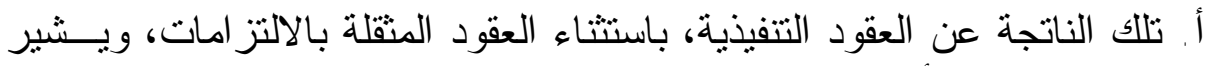

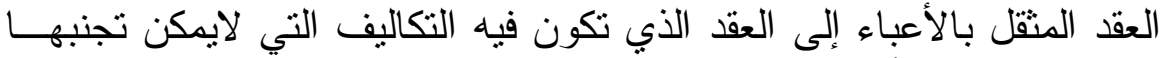

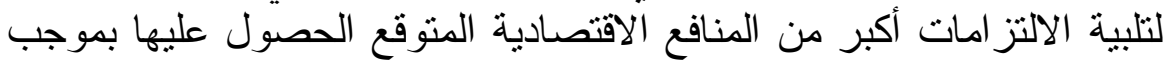

$$
\text { العقد . }
$$

ب. بلتك التي تغطيها معايير أخرى.

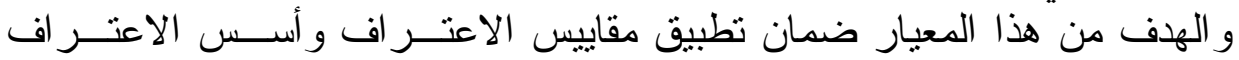

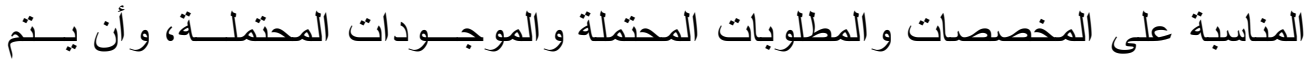
الإفصاح عن معلومات كافية في إيضاحات البياتيات اليات المالية لتمكين المستخدمين من فهم

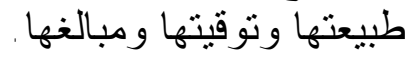




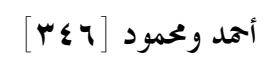

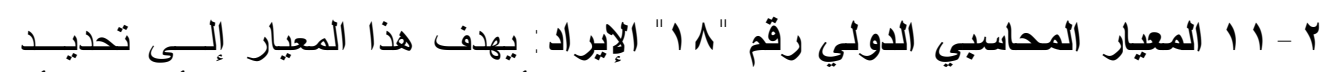

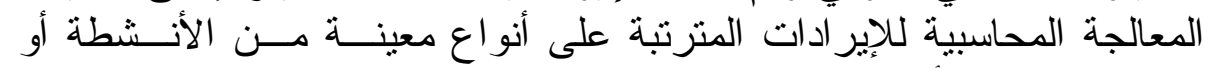

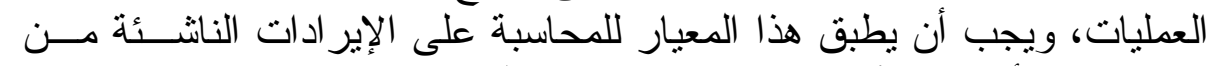

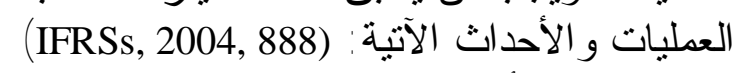

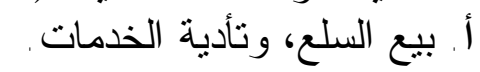
ب. استعمال الغير لموجودات الوات الوحدة الاقتصادية وما ينتج عنها من فو ائد، حقوق

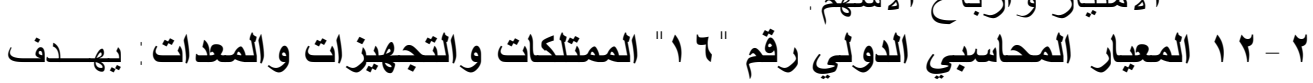

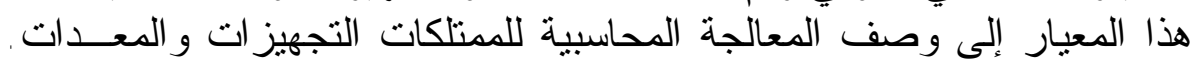

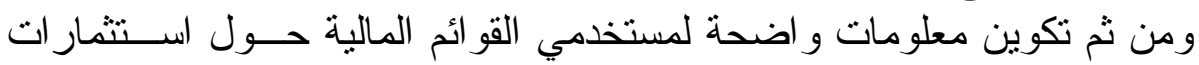

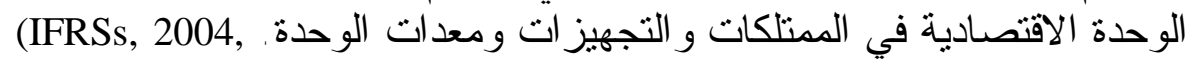

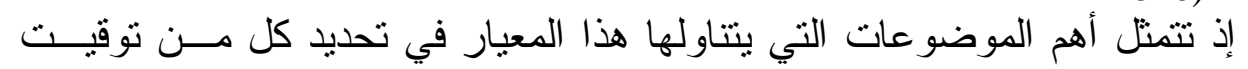

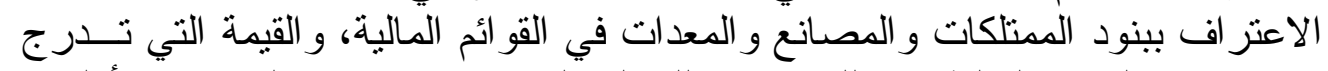

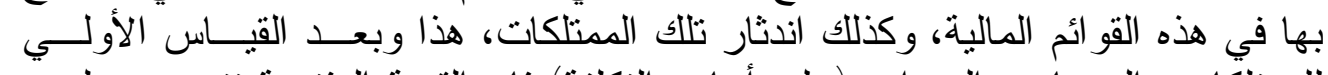

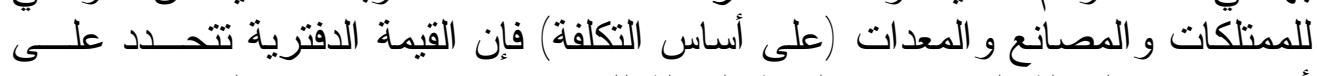

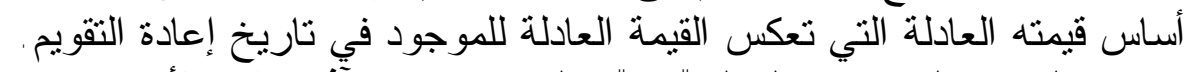

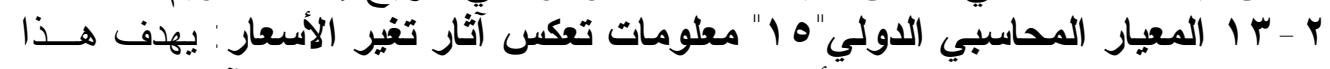

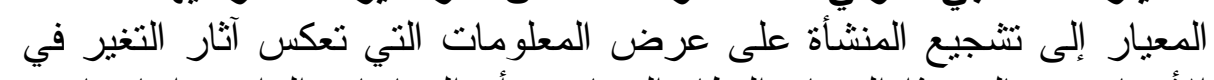

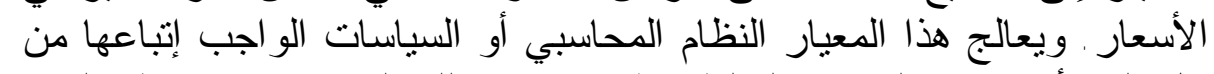

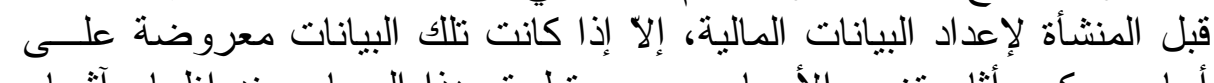

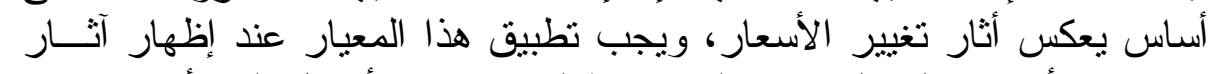
تغير ات الأسعار على المقاييس المستخدمة لتحديد نتائج أعمال المنشأة ومركز هار

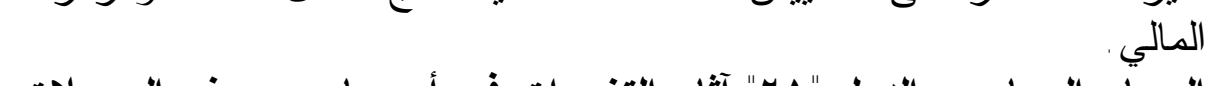

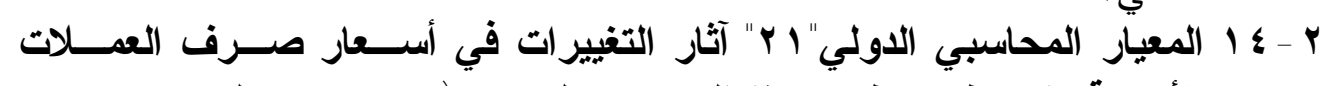

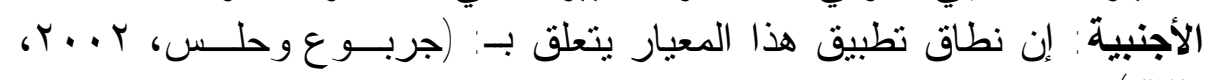

(rrt

1 ا ـ المحاسبة عن المعاملات بالعملة الأجنبية. r ا ترجمة القو ائم المالية للعمليات الأجنبية والتي ينتم تضمينها في القوائم المالية للمنشأة.

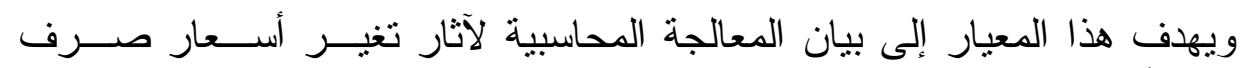

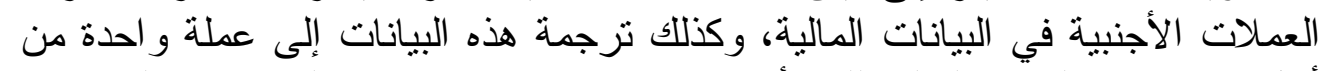

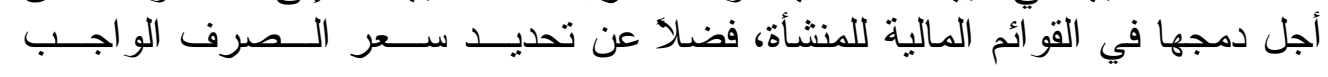




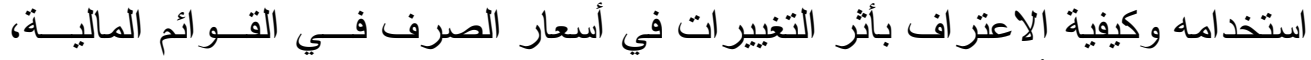

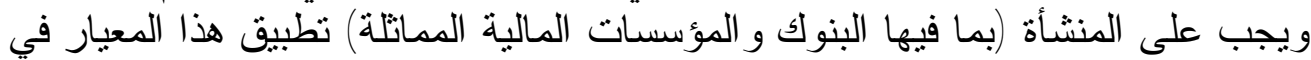

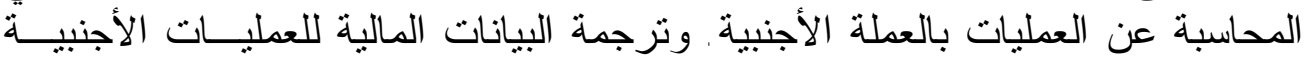

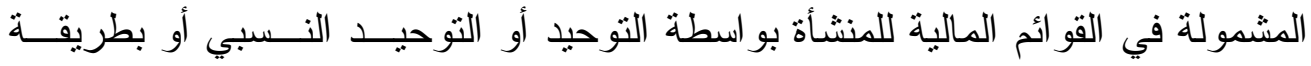

r -0 المعيار المحاسبي الدولي رقم "ب ب" تكلقة الاقتر اض: حدد المعيار معسالجتين

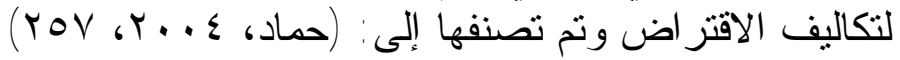

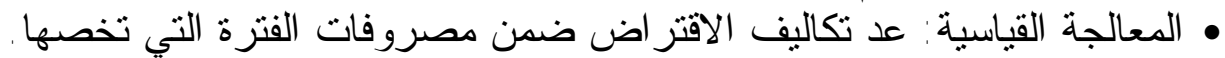

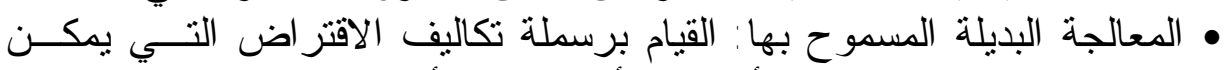

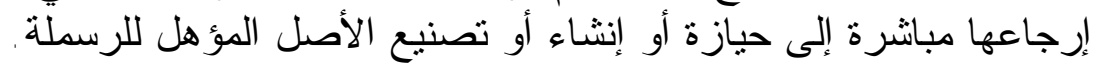

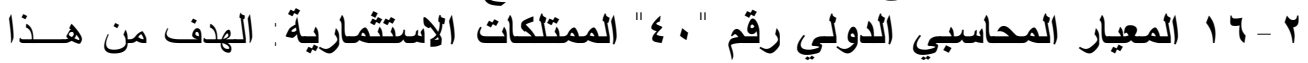

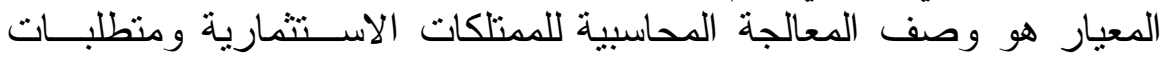

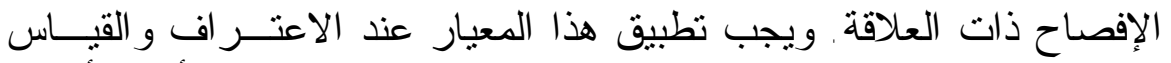

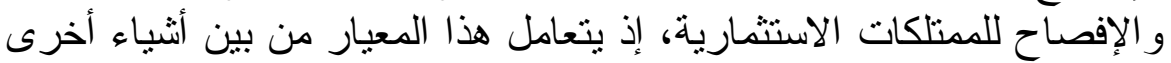

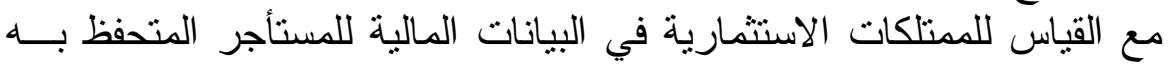

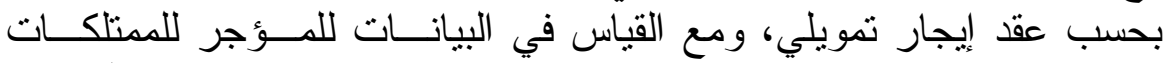

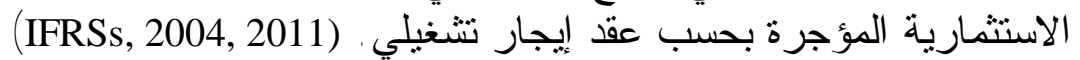

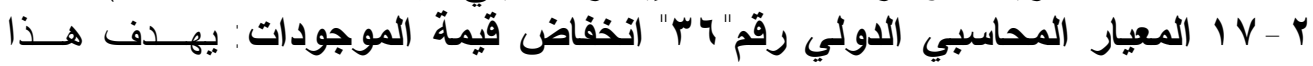

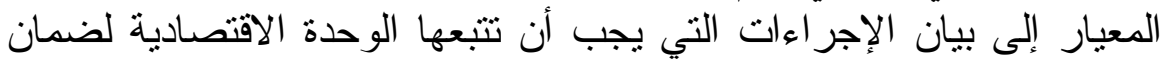

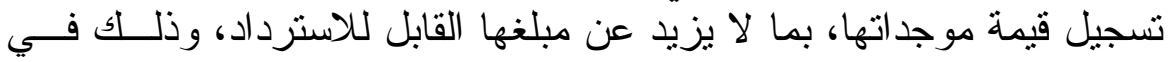

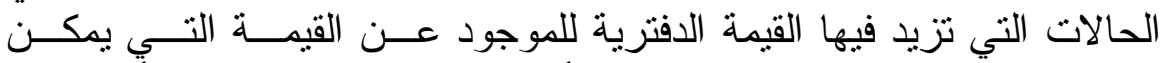

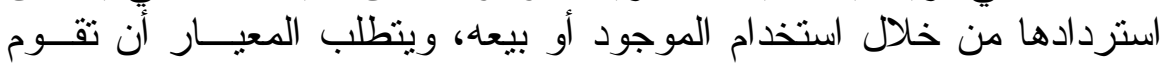

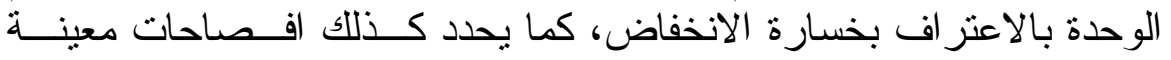

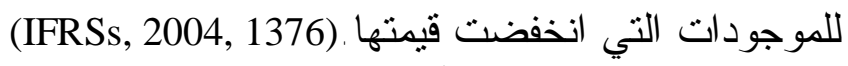

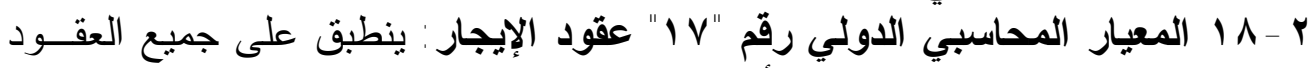

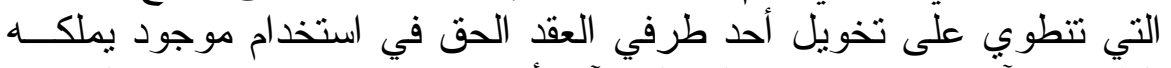

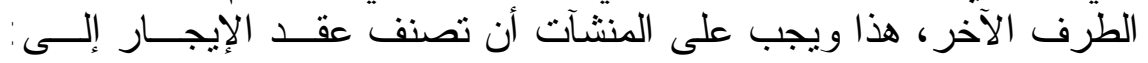
(IFRSs, 2004, 861) أ.عقد الإيجار التمويلي في الحالات الآتية:

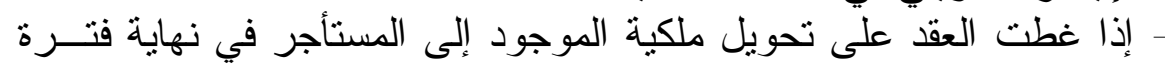
العقد . - إذا تضمن العقد حقاً اختيارياً للمستأجر لشر اء الموجود بسعر يتوقع أقــــل

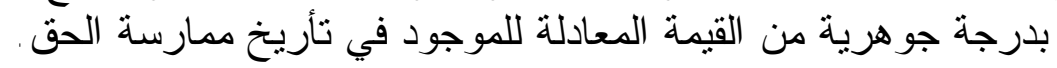


أحمد ومحمود [rی^]

- إذا تغطي فترة الإيجار الجانب الأكبر من العمر الاقتصادي للموجود .

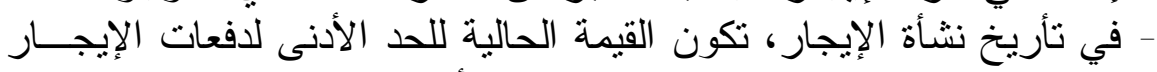

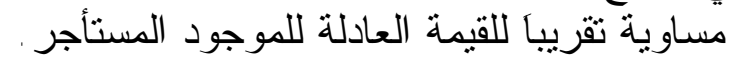

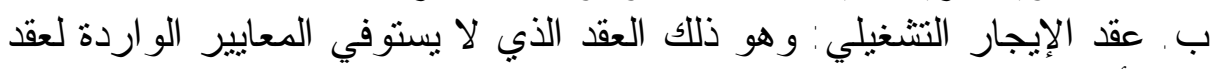

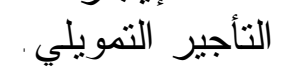

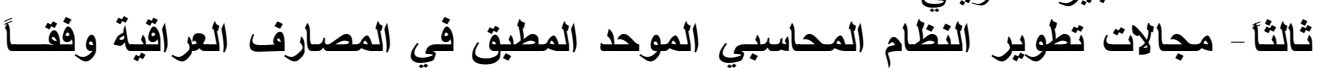

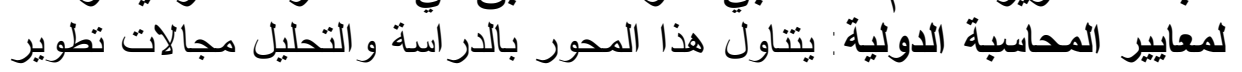

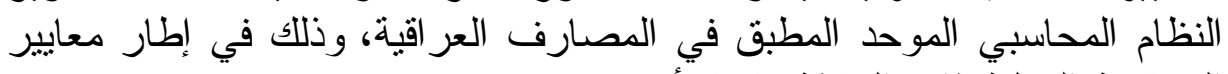

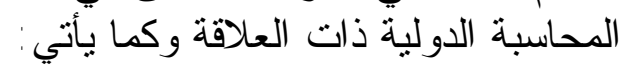

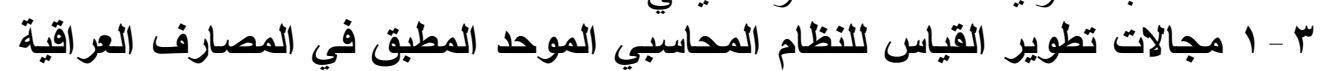

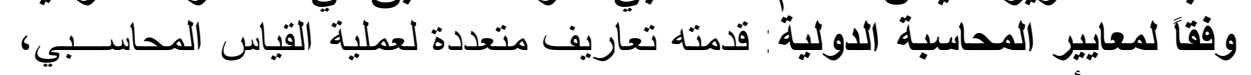

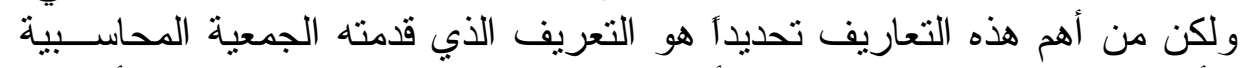

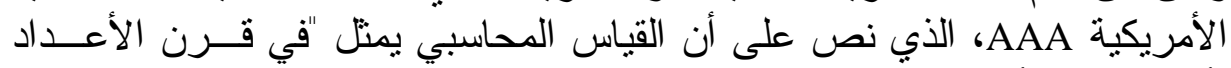

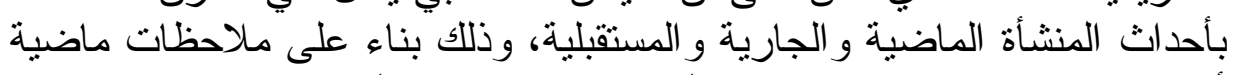

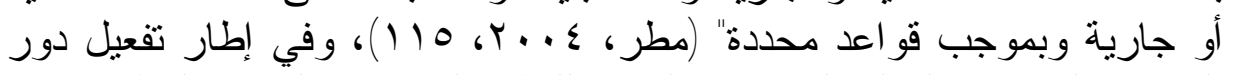

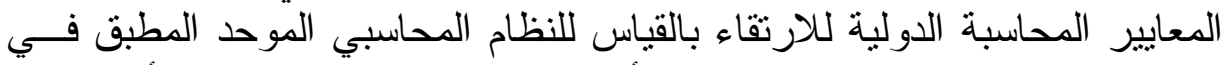

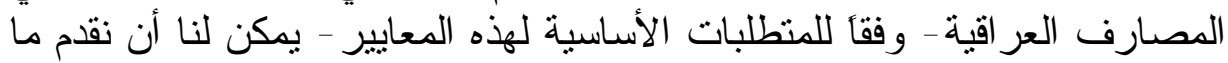

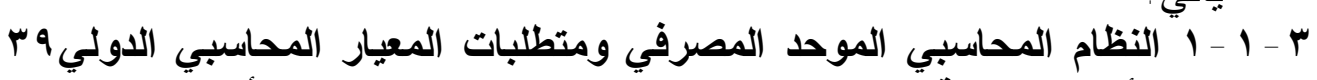

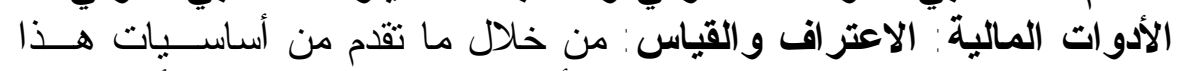

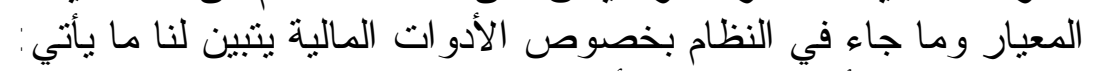

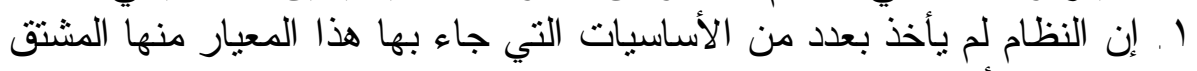

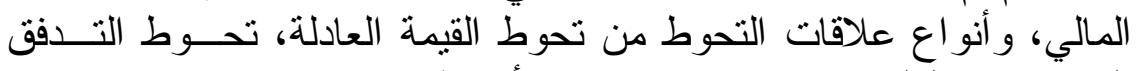

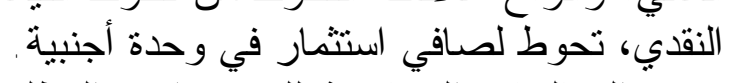

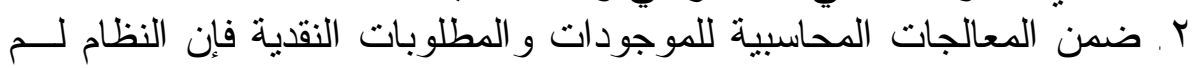

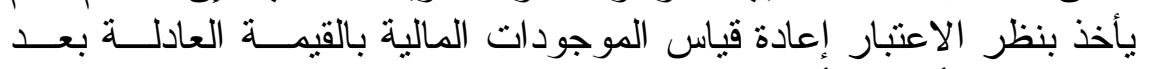

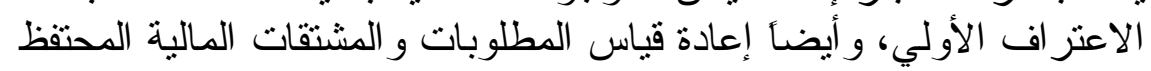

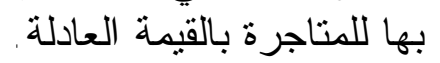

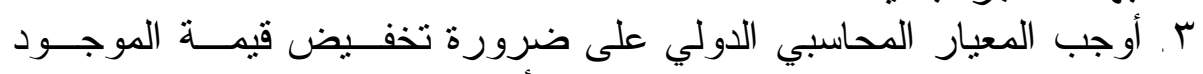

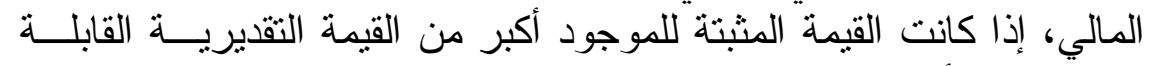

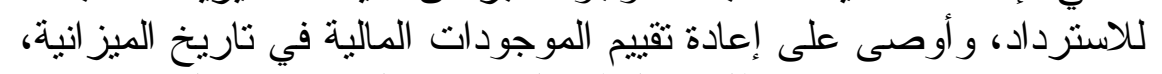

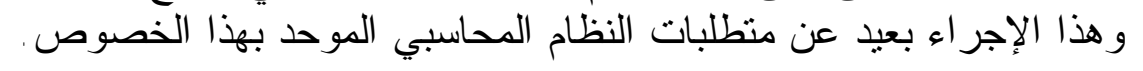




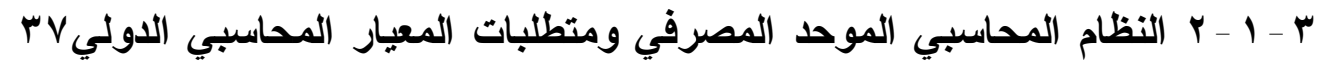

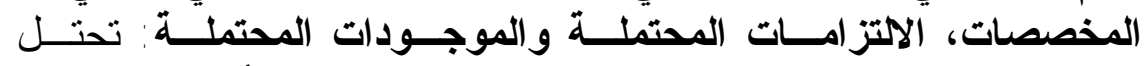

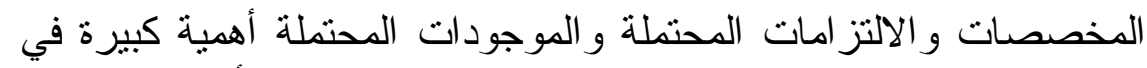

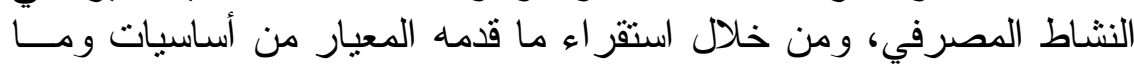

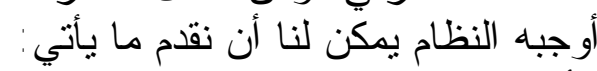

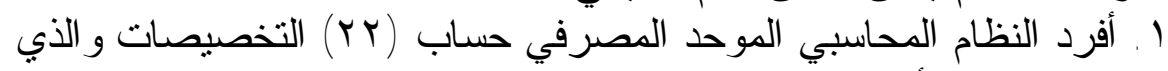

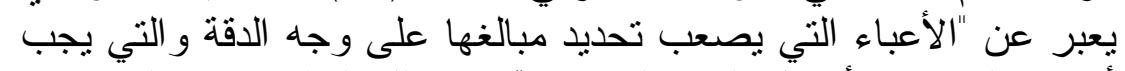

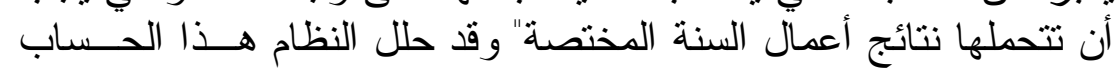

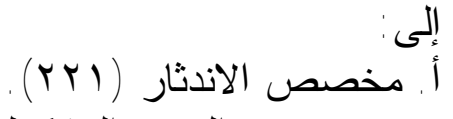

ب. مخصص الديون المشكوك في تحصيلها (Yr (Y (Y) ).

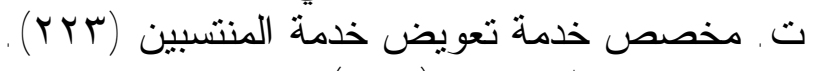

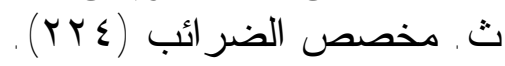

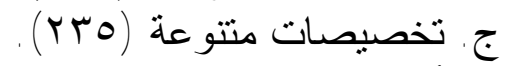

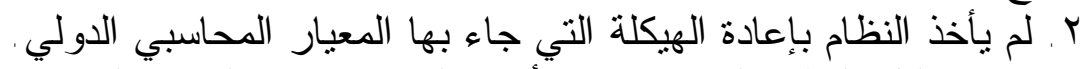

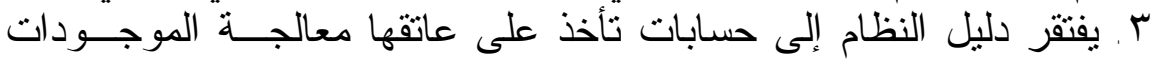

$$
\text { و المطلوبات المحتملة. }
$$

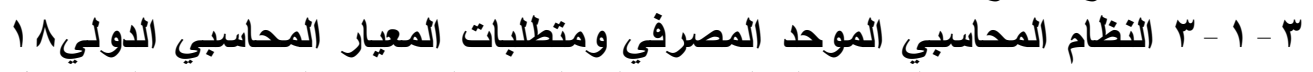

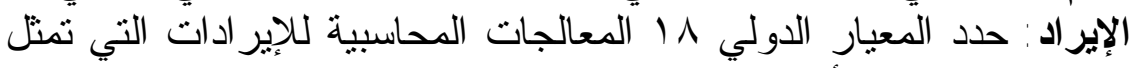

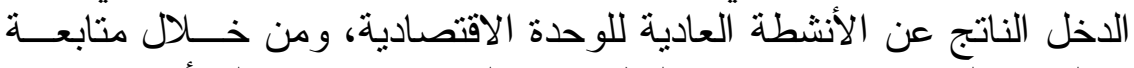

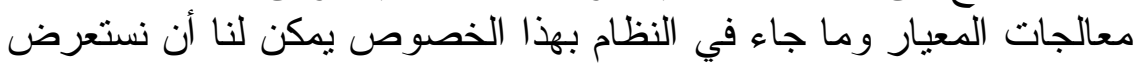
ما بأتي : مالجان

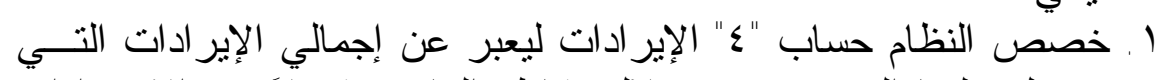

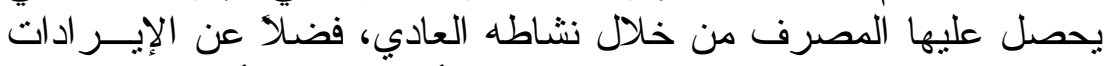

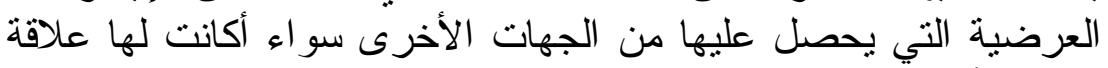

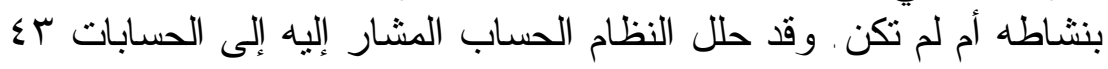

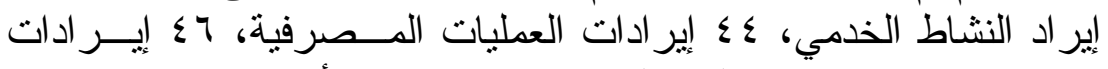

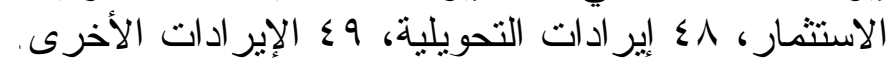

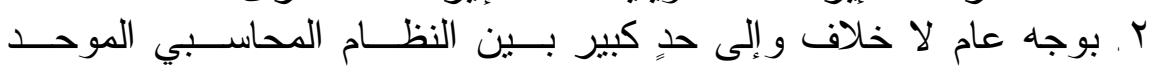

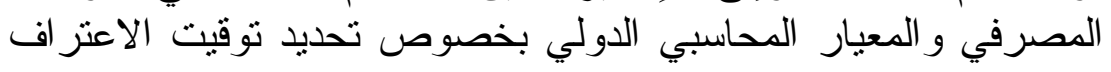
بالإير ادات. r. أكد المعيار المحاسبي الدولي أنه إذا نم تأجيل استلام النقدية أو النقديــة

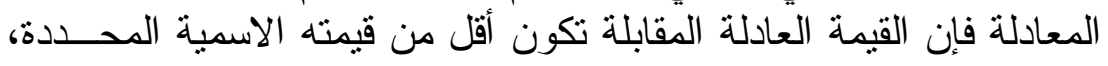


[ro. [ أحد ومحمود

ويعامل الفرق بين القيمة الاسمية و القيمة العادلة بوصفه إير اد فو ائد، في

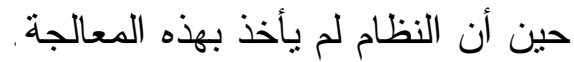

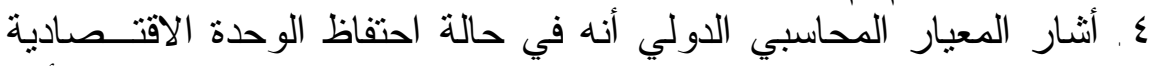

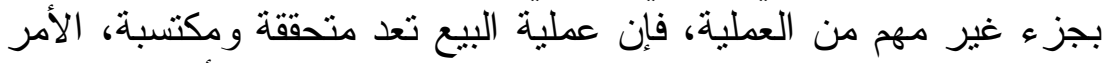

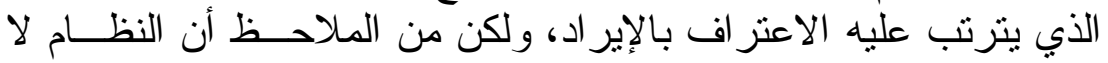

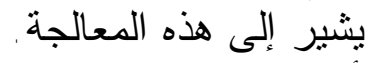

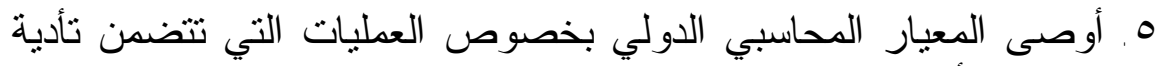

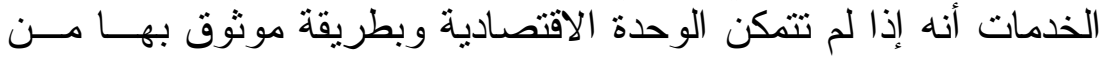

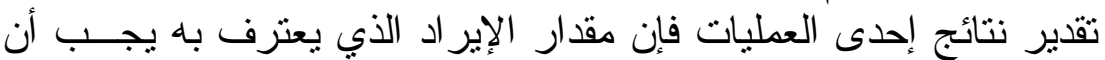

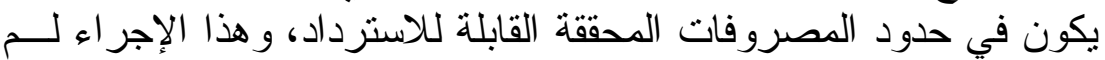
يأخذ به النظام . 7 ـ أكد المعيار أنه يتعين على الوحدة الاقتصادية الاعتز اف بالأتعاب بوصفها

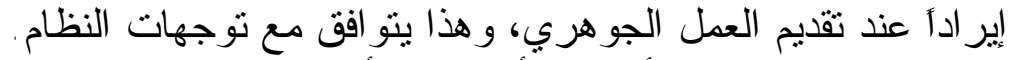

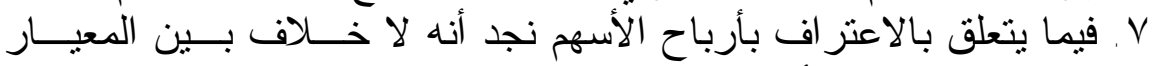

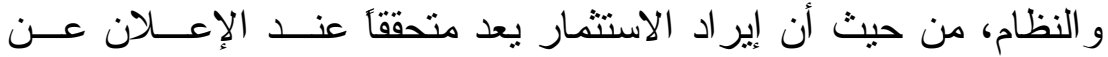

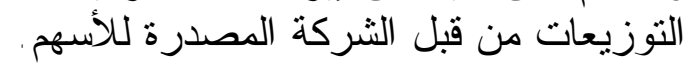

r - 1 - ـ النظام المحاسبي الموحد المصرفي ومتطلبات المعيار المحاسبي الدولي 17

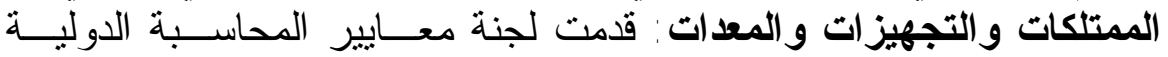

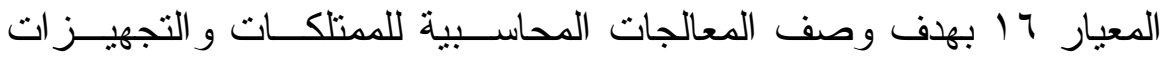

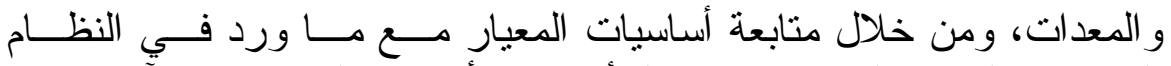

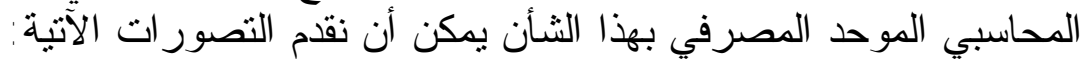

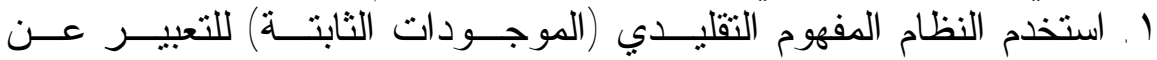

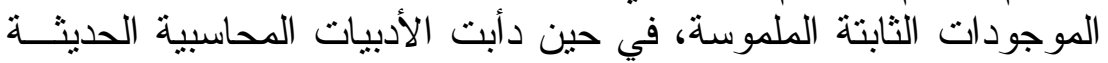

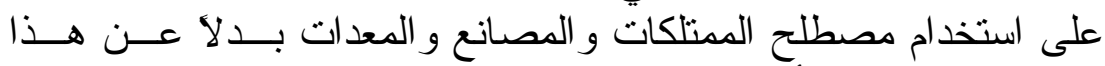

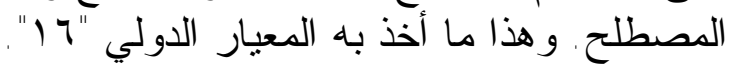

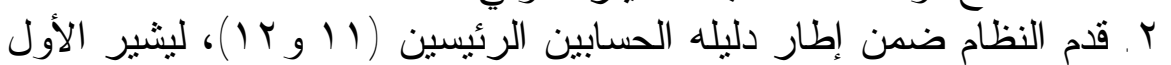

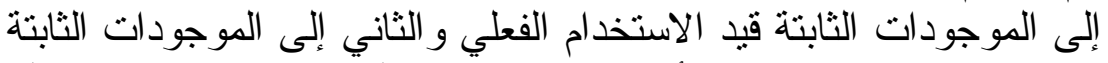

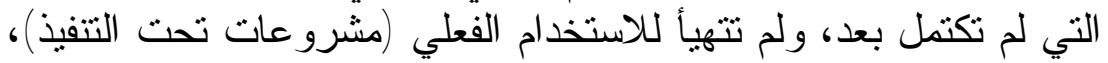

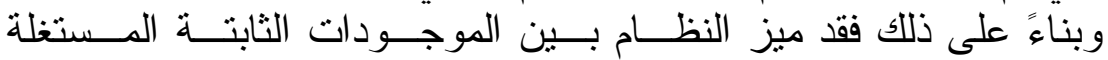

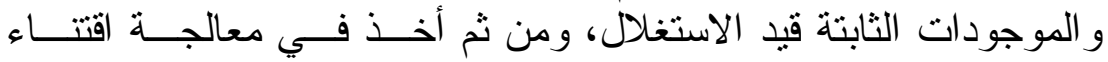

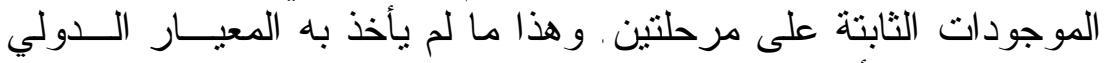

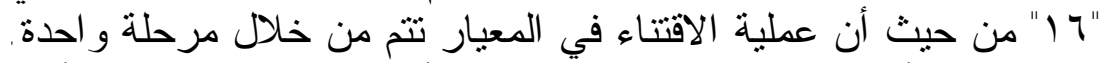

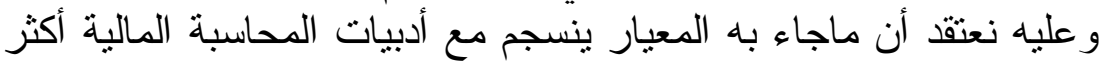


مما قدمه النظام، إذ تشير أدبيات المحاسبة المالية إلى أن المــصروفات

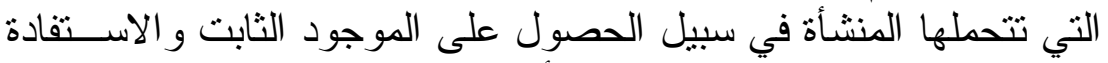

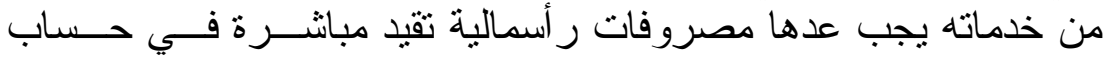
الموجود .

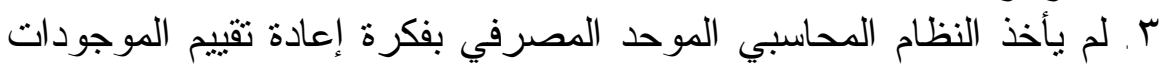

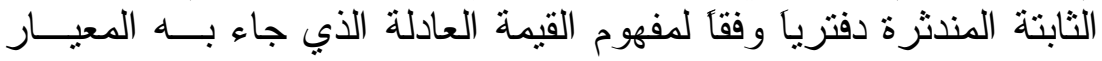

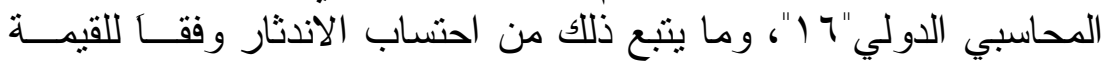
العادلة بعد إعادة التقييم، و احتساب مكاسب وخئ وخسائر إعادة التقبيم و إثباتها في السجلات المحاسبية. ع ـ ألزم النظام طريقة القسط الثابت في احتساب اندثار الموجودات الثابتة، في

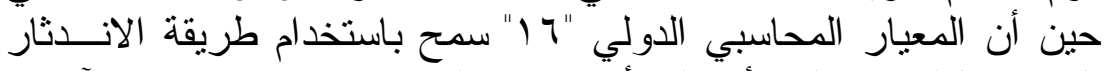

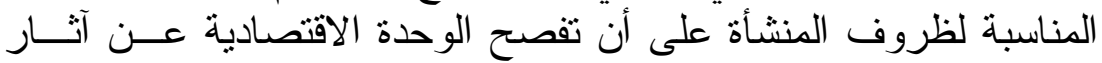

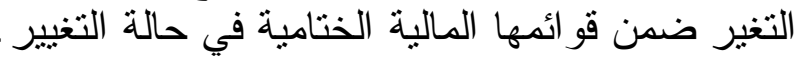

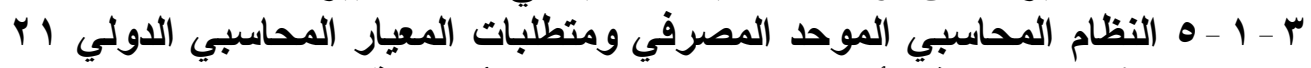

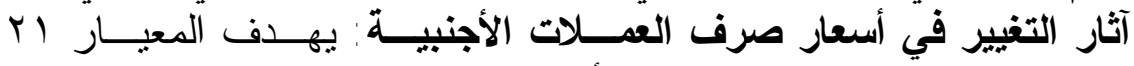

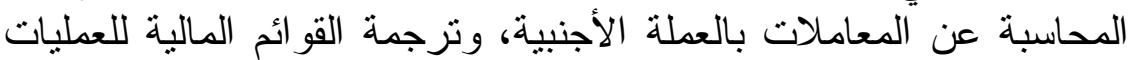

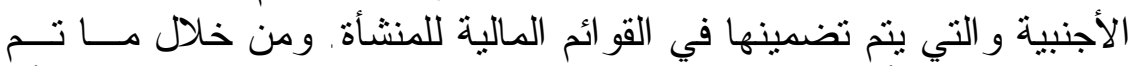

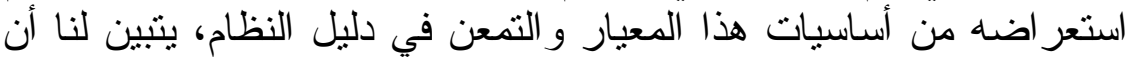
النظام قد أفرد لمعالجة آثار التغيير في الأسعار كل من فن الحسابات :

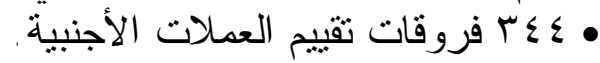

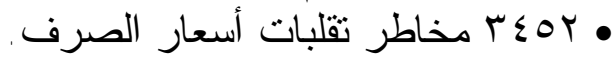
ل

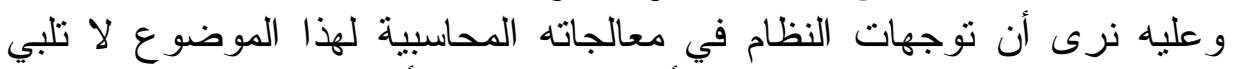

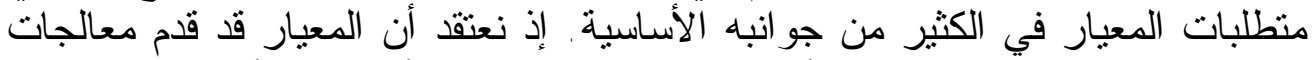

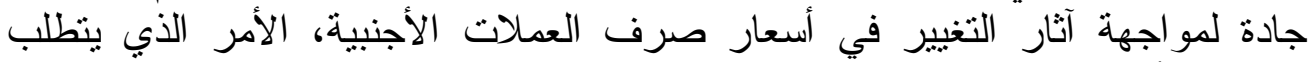

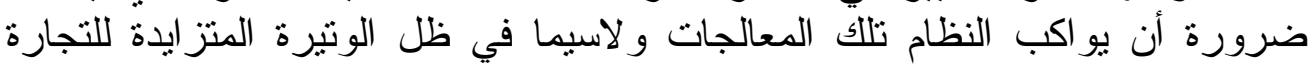

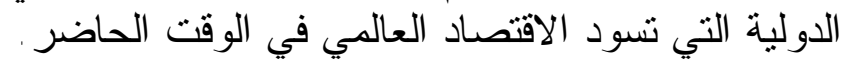

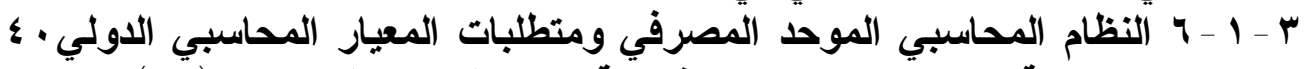

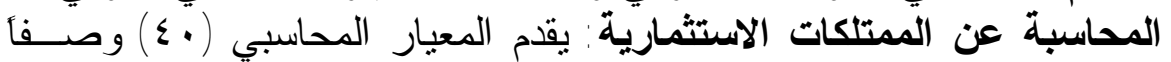

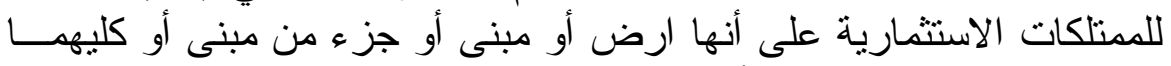

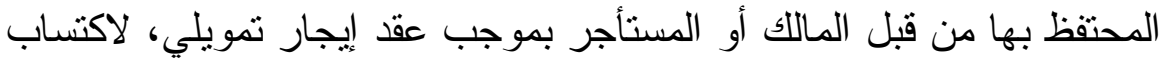
إير اد إيجاري، أو للاستفادة من ارتفاع قيمتها الر أسمالية أو كليهما. 


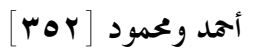

ومن خلال ماتم استعر اضه من أساسيات المعيار وملاحظة ما وردت في النظام

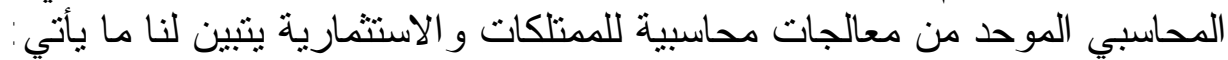

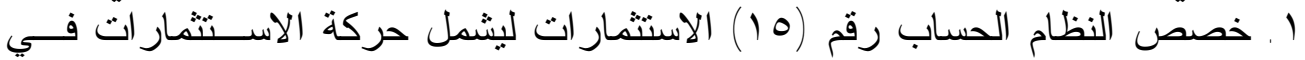

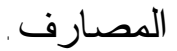

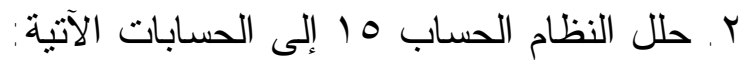

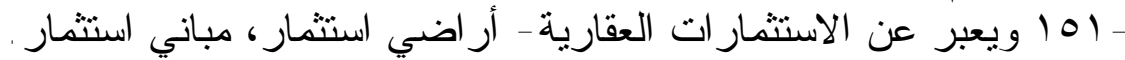

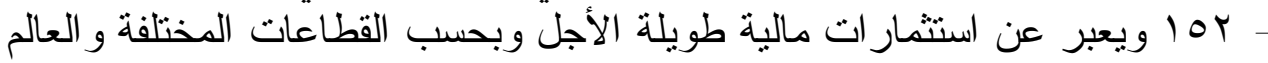
ـ س الع ويعبر عن استثمار ات مالية قصيرة الأجل وبحسبس القطاعــات المختلفــة و الخارجي العالم ويعبر الخار

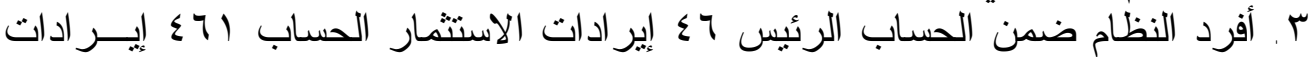
الاستثمار ات العقارية.

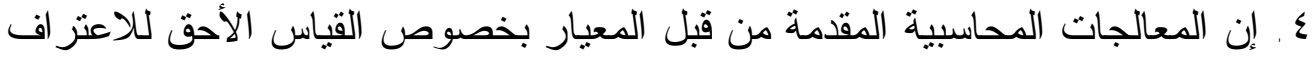

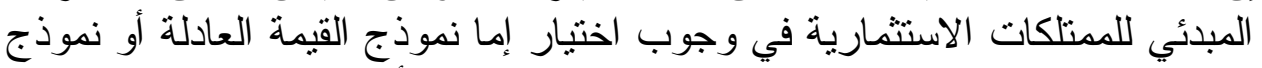

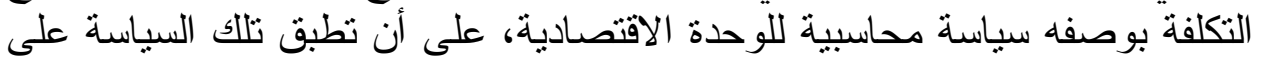

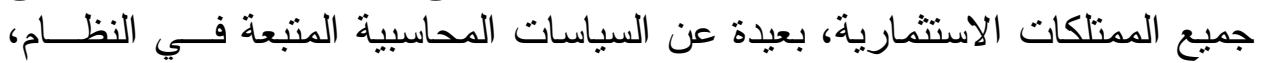

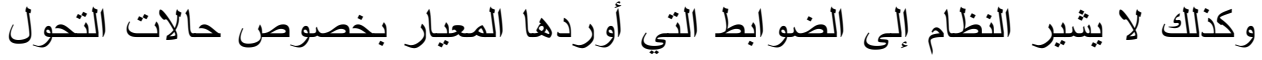

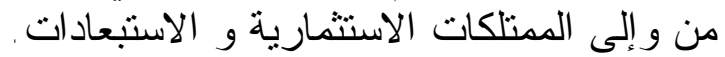

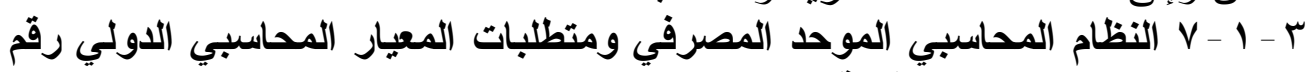

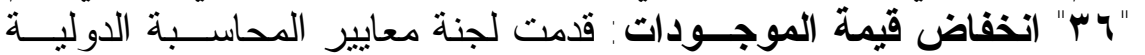

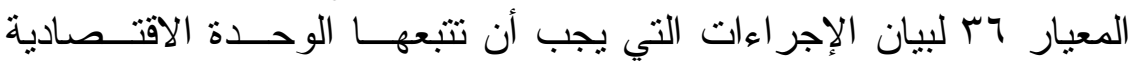

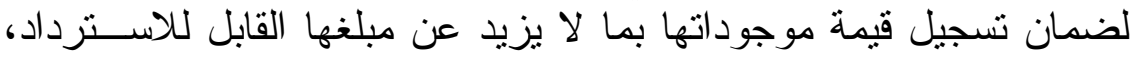

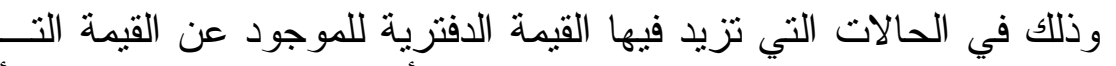

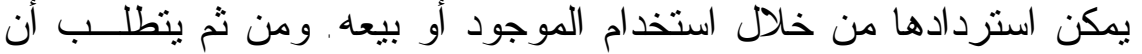

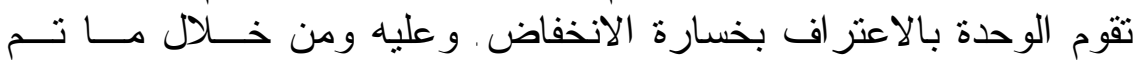

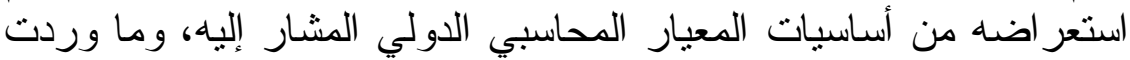

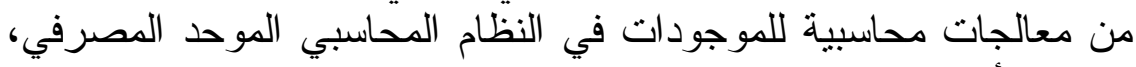

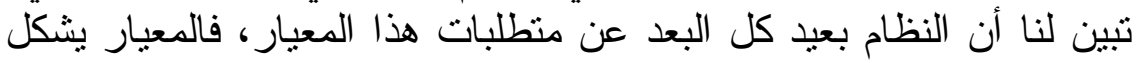
حالة متقدمة في مو اجهة انخفاض قيمة الموجودات التون التي يقضضي من النظام

$$
\text { ضرورة مو اكبتها. }
$$

r - 1 -1 النظام المحاسبي الموحد المصرفي ومتطلبات المعيار المحاسبي الاولي رقم

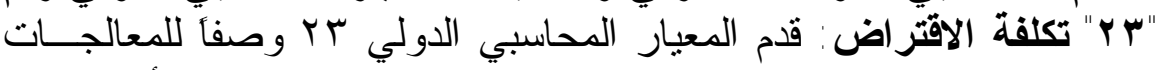

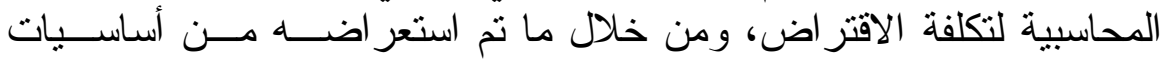


المعيار، وما جاء به النظام المحاسبي الموحد المصرفي يمكن لنا أن نقام ما

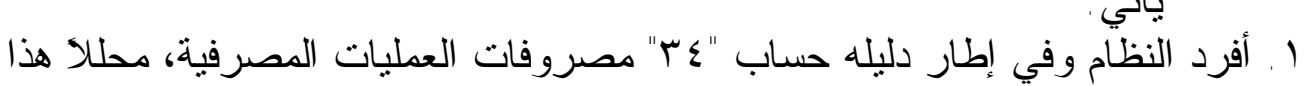

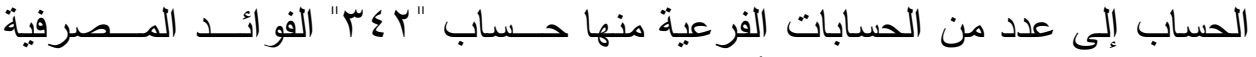

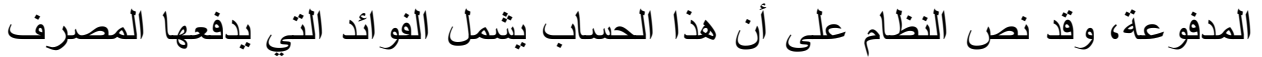

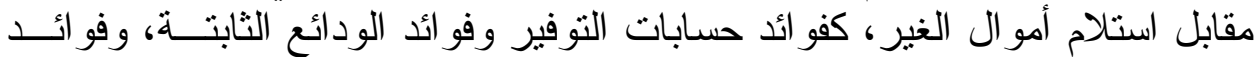

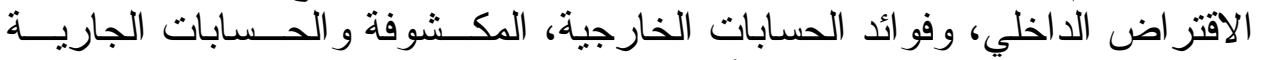

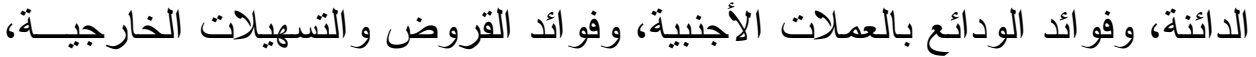

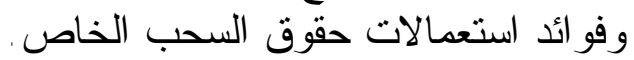

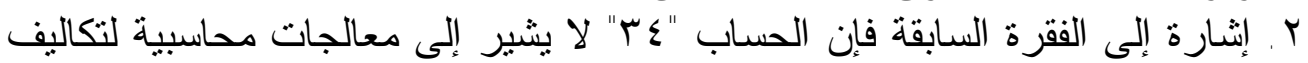

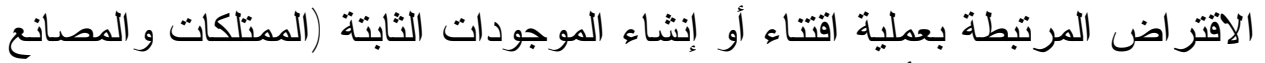

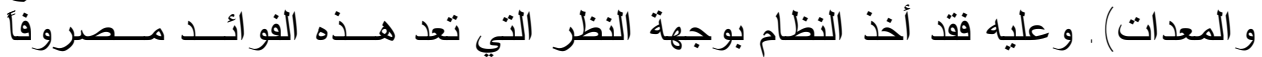

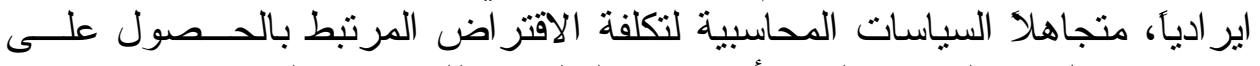

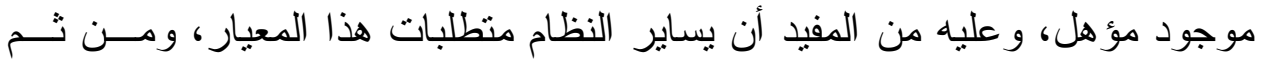

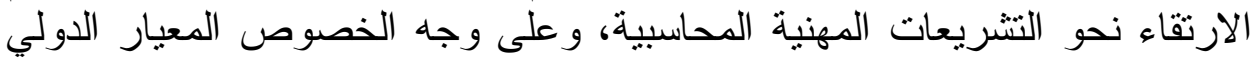

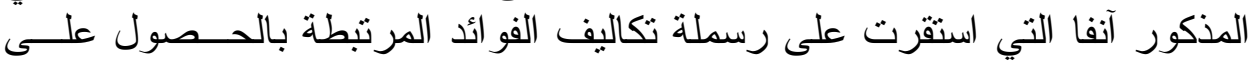

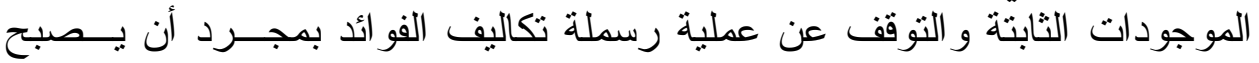

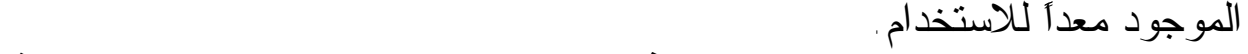

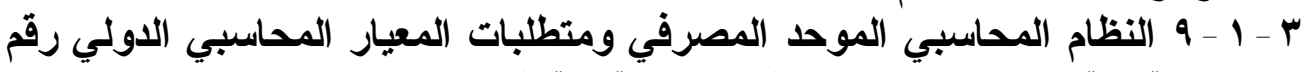

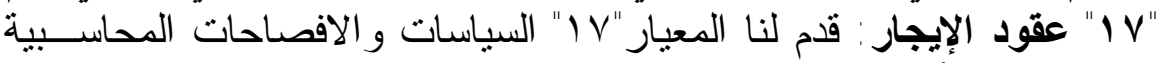

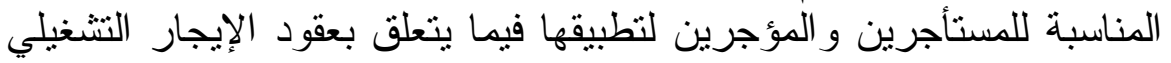

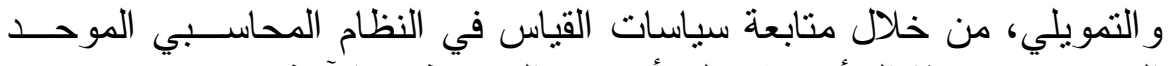

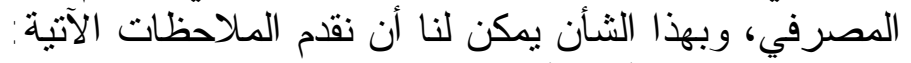

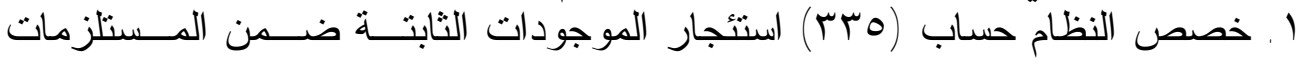

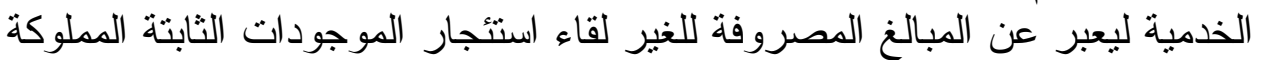

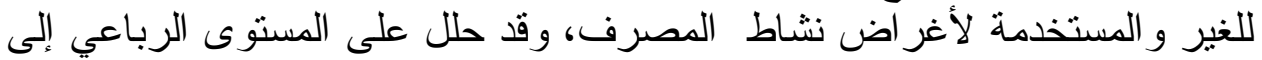

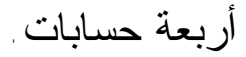

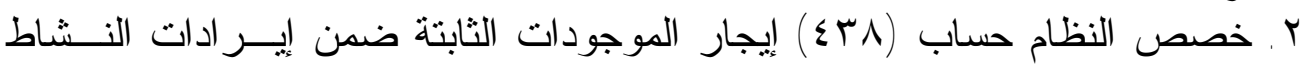

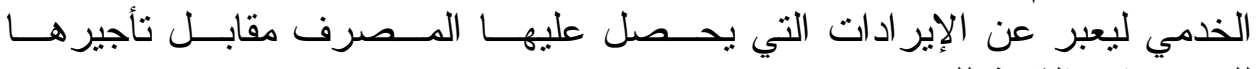

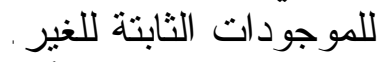

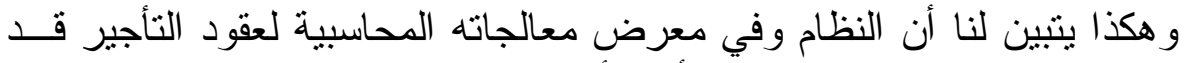

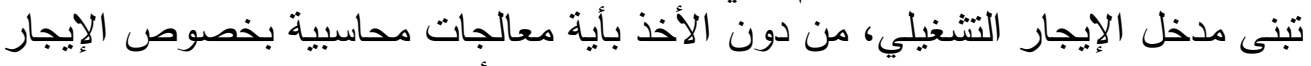
التمويلي، وعليه فإن النظام بهذه المعالجات بعيد عن أسس تصنيف عقود الإيجار بين الإين 


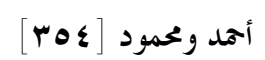

الإيجار التمويلي والإيجار التشغيلي، كما تم الإشارة إليه سابقأ من أسس التصنيف في

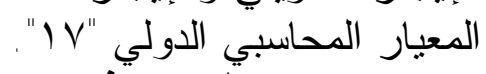

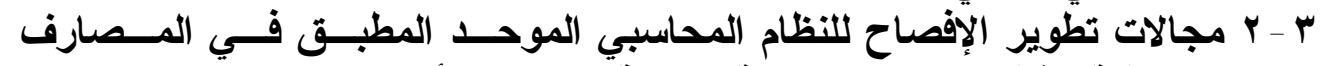

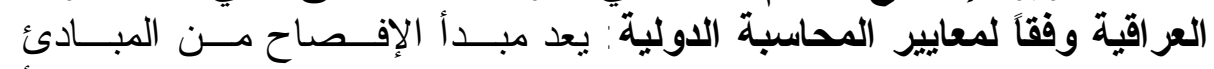

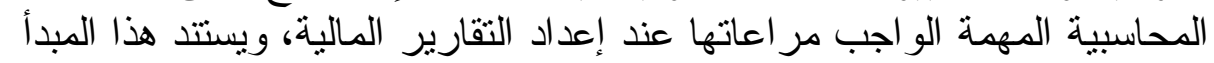

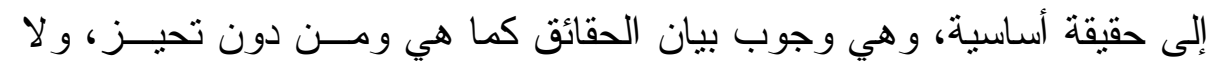

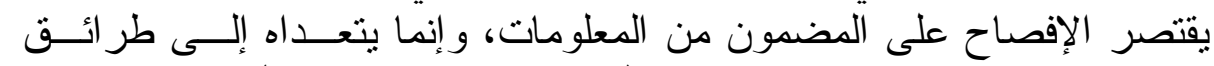

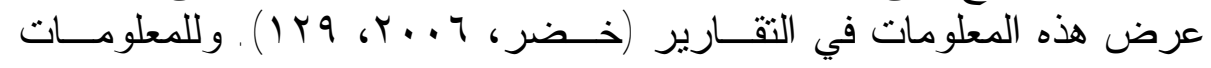

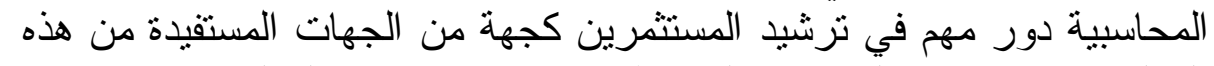

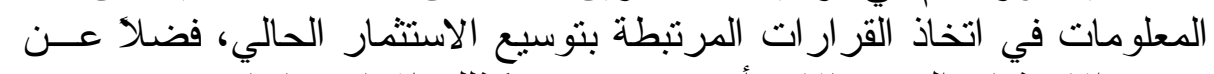

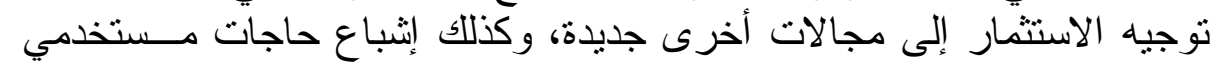

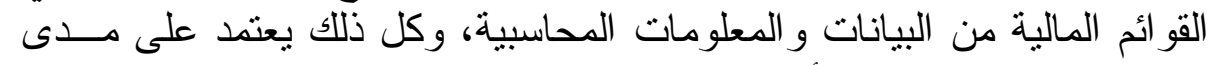

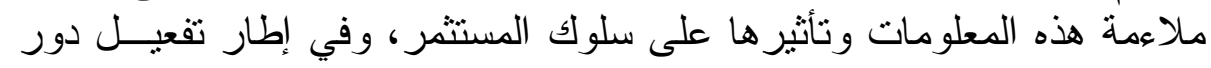

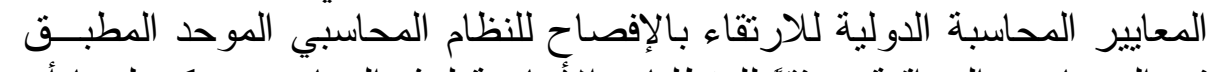

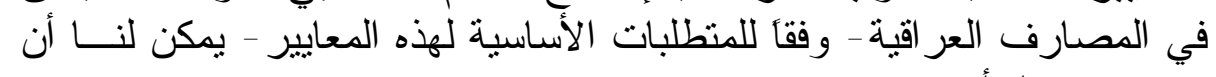

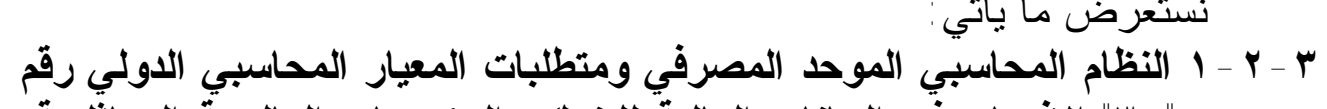

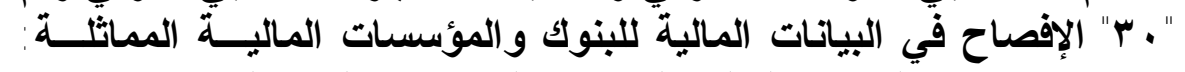

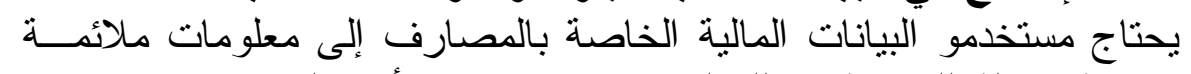

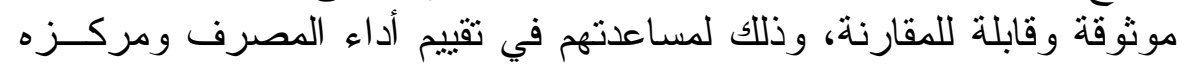

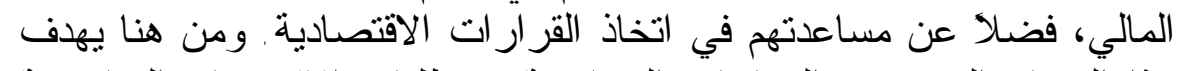

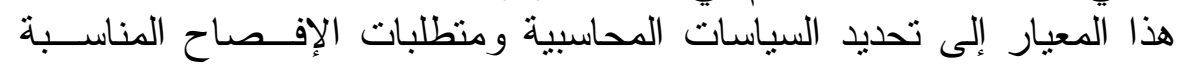

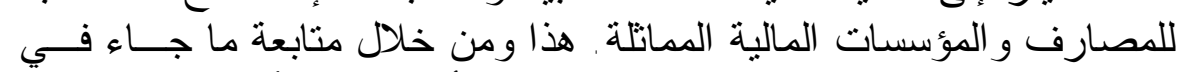

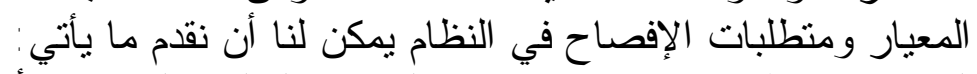

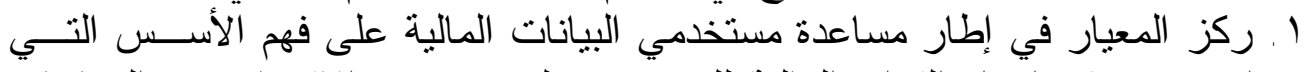

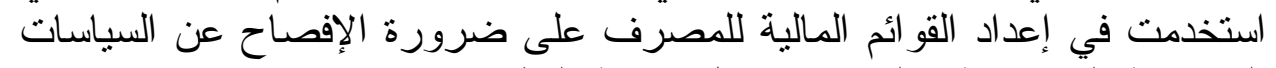

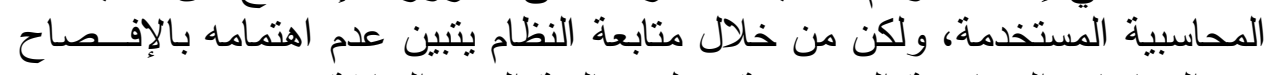

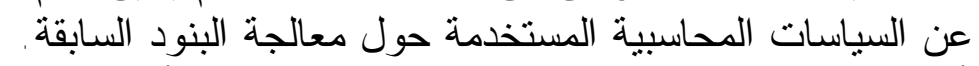

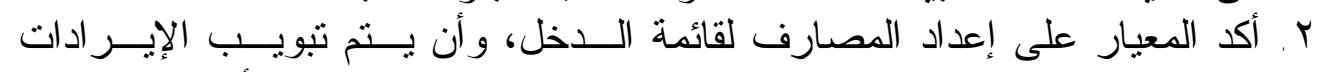

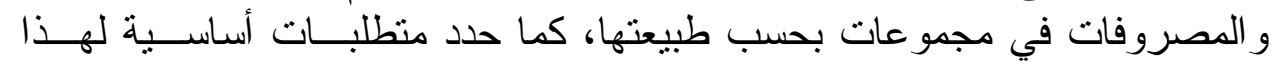

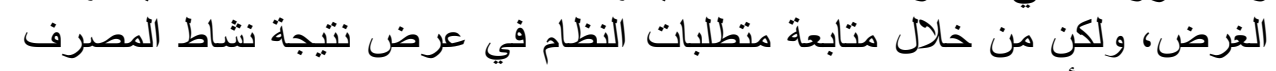
يتبين لنا ما يأتي : 2 الغن من 


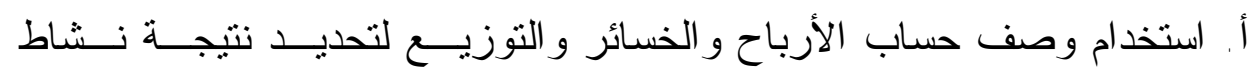

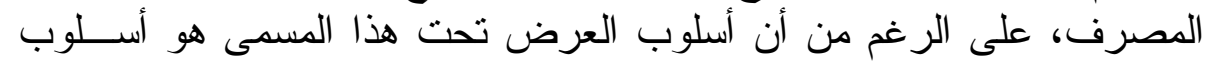

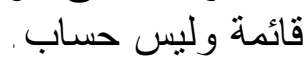

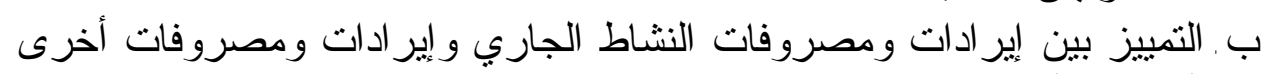
(التحويلية). ت.تحديد نتيجة النشاط على مرحلتين، مرحلة فائض (عجز ) العمليات الجاريــة،

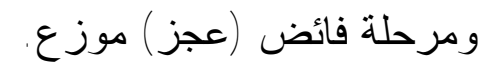

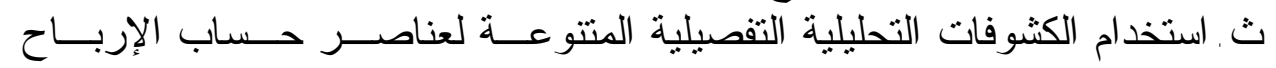

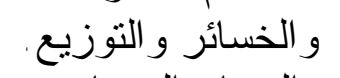

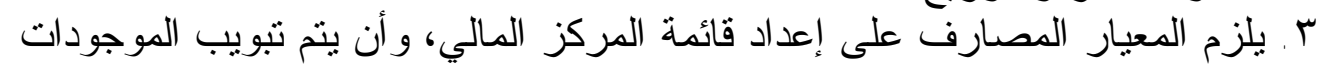

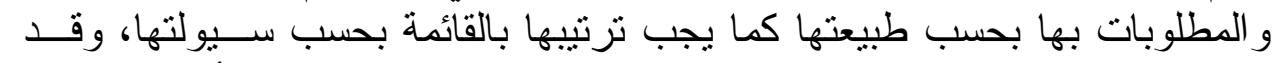

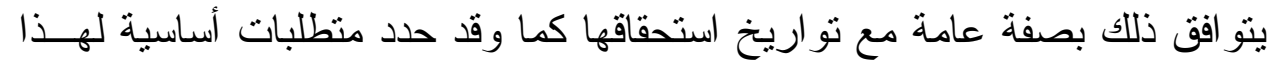

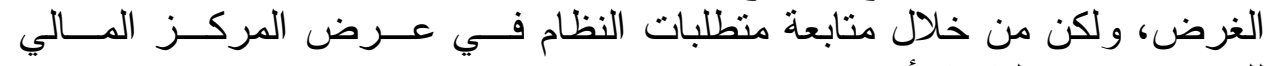

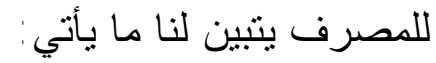

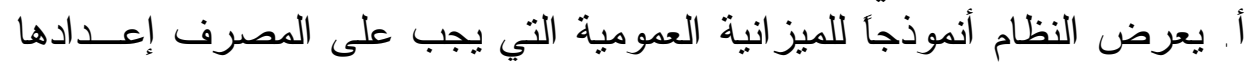

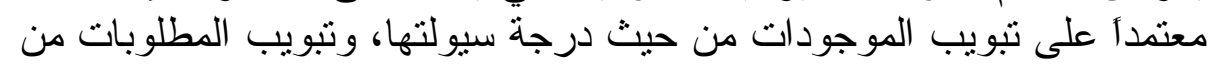

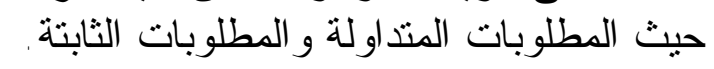

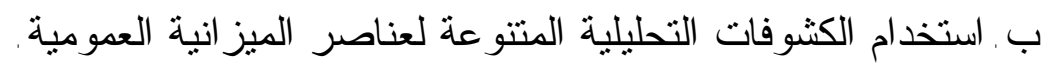

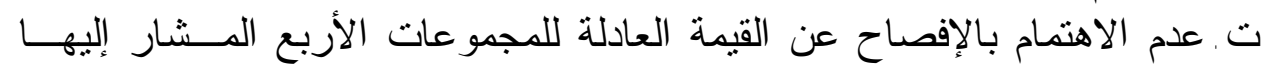

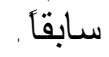

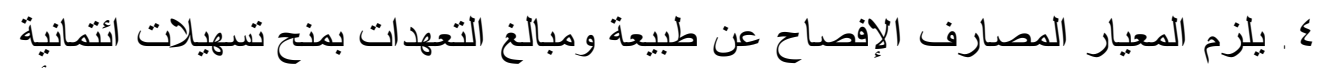

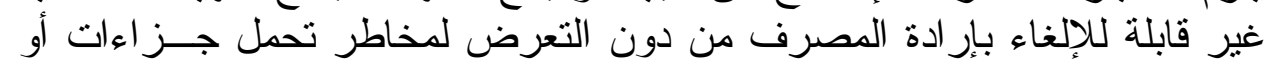

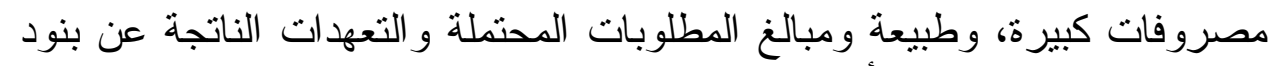

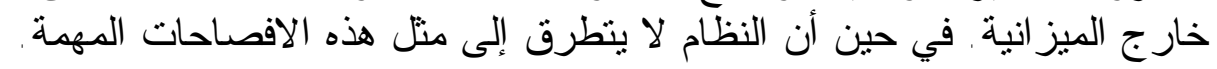

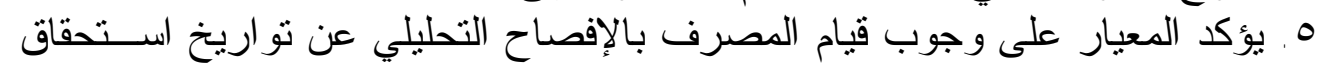

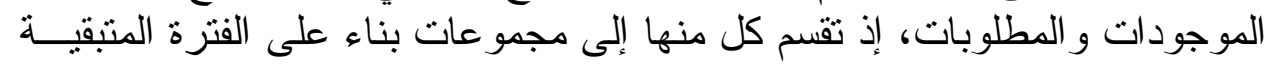

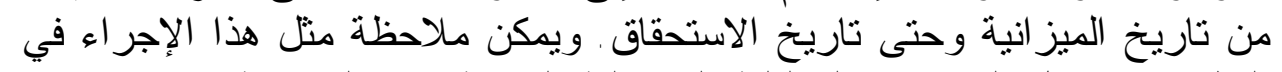

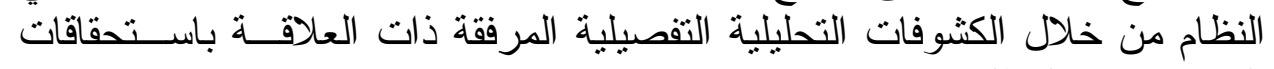

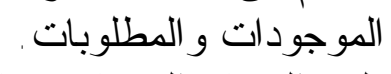

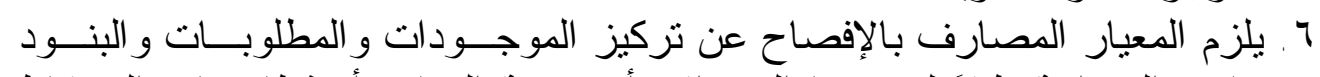

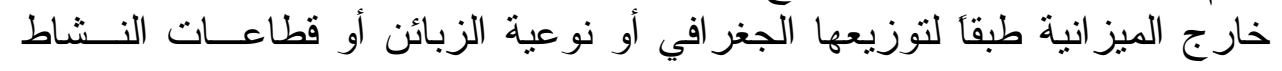


[ror] أحد ومحمود

و غير ها من تزكيز المخاطر، ويمكن ملاحظة منل هذا التوجه في النظام من خلال

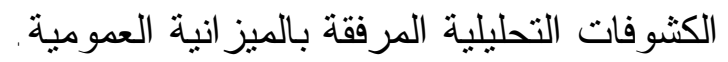

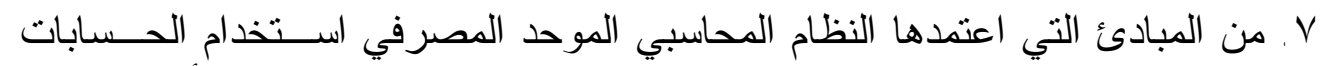

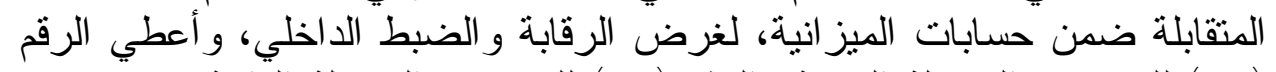

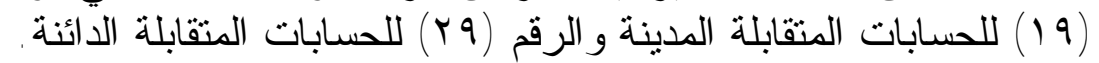

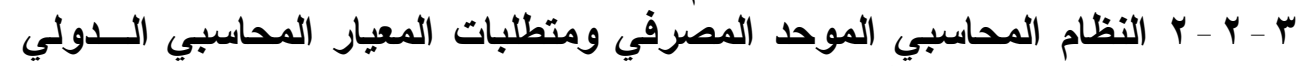

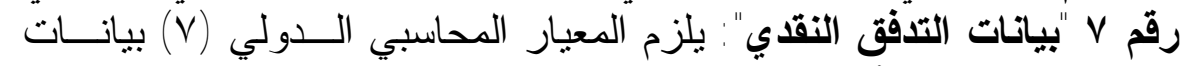

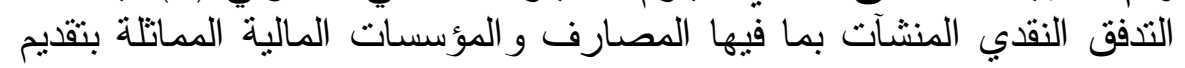

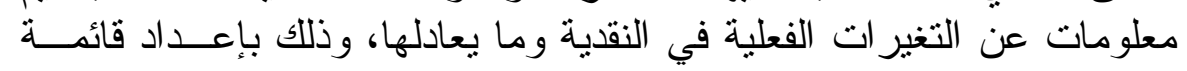

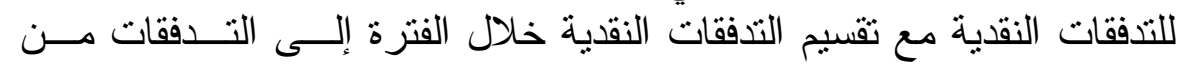

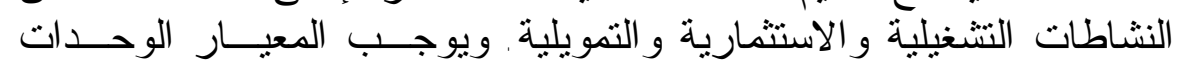

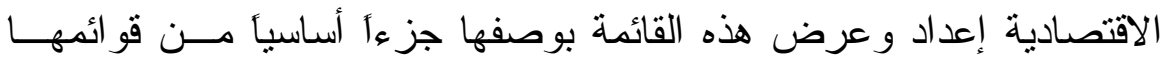

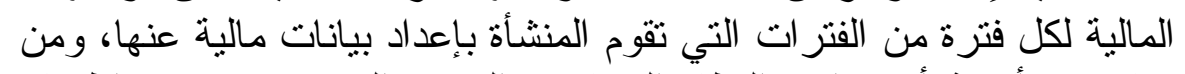

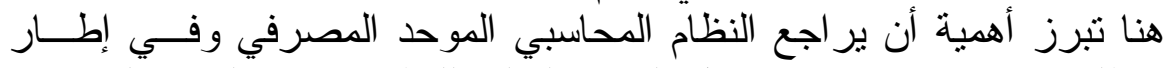

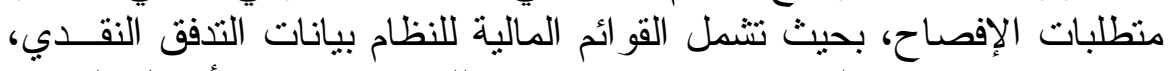

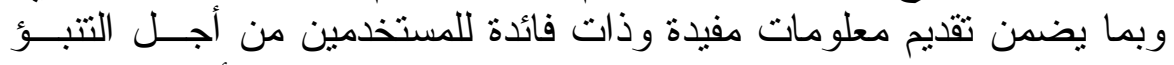

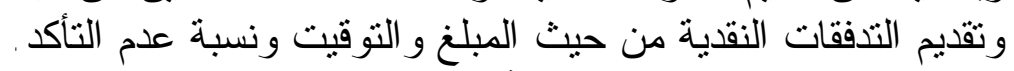

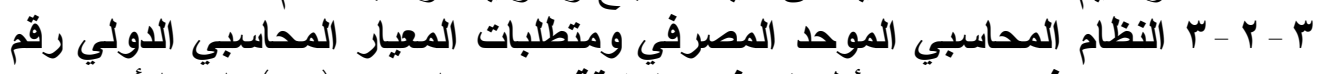

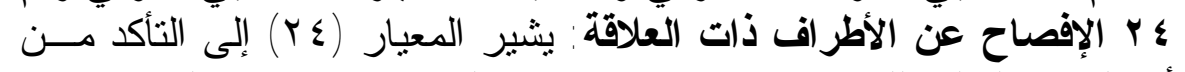

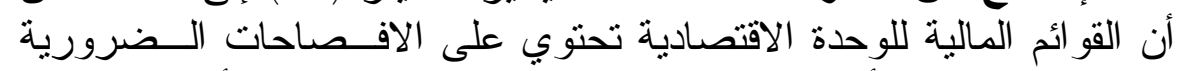

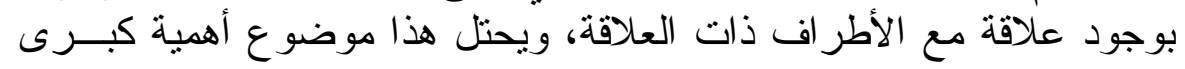

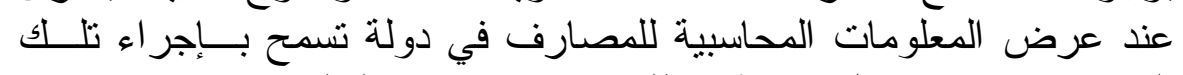

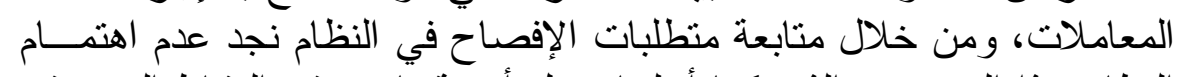

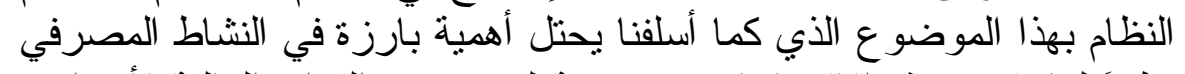

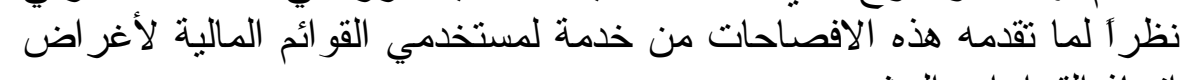

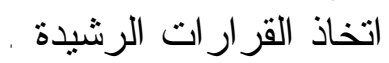

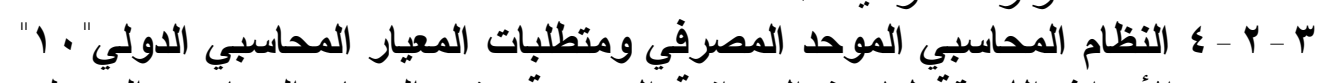

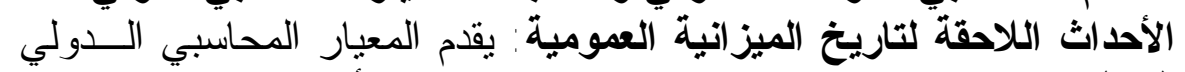

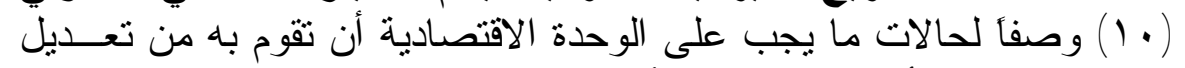

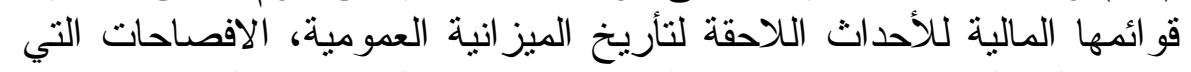

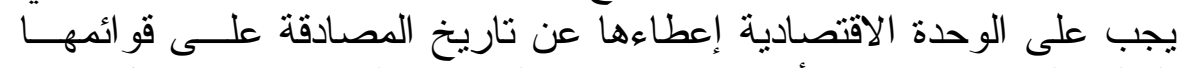

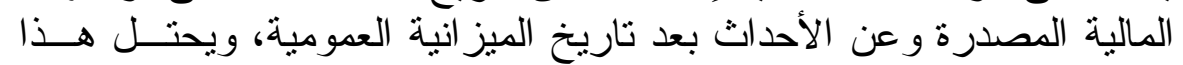

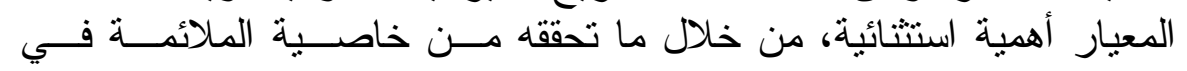


المعلومات المحاسبية (الثز امن) التي يجب على المنثأة مر اعاتها عند تـــوفير

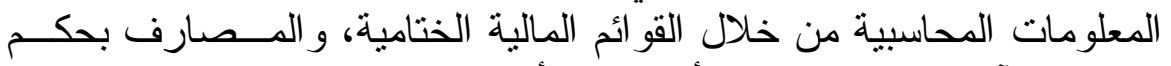

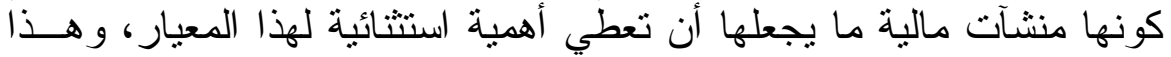

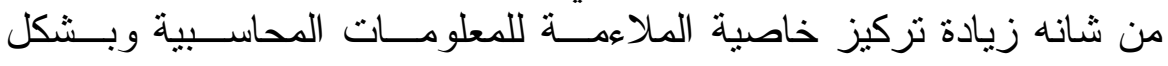

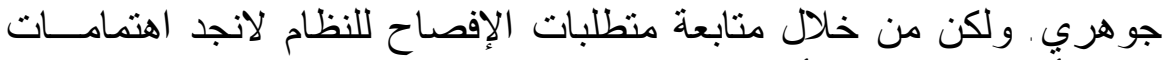

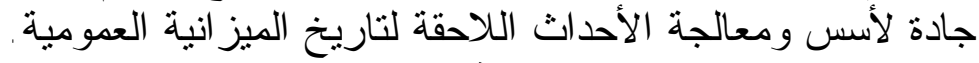

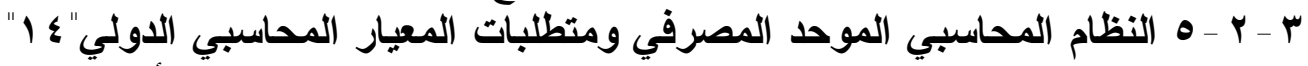

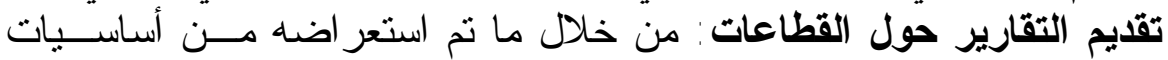

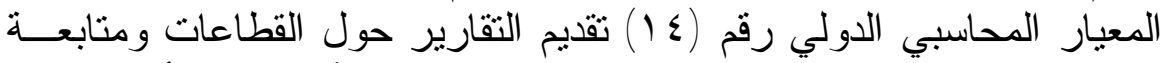

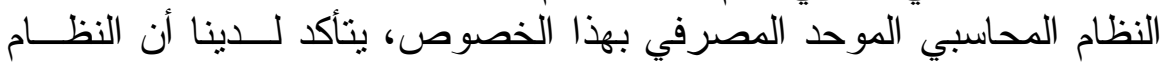

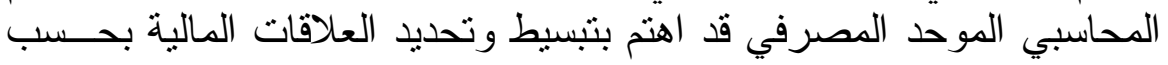

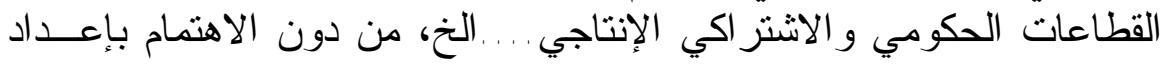

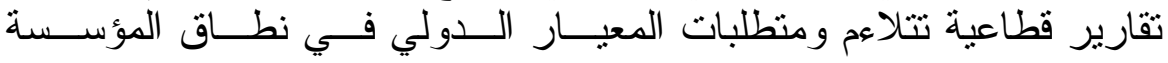

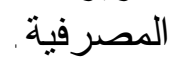

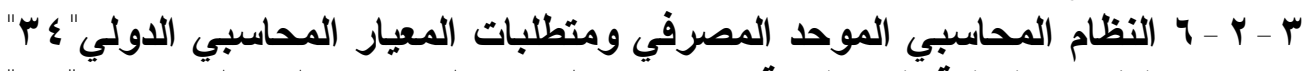

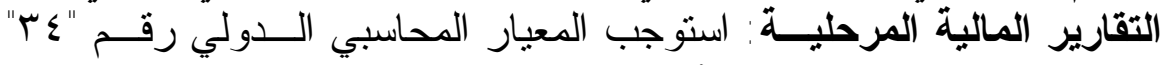

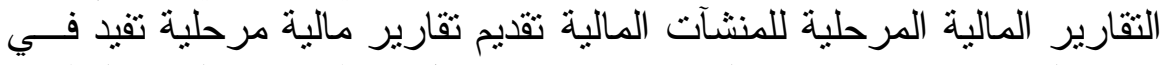

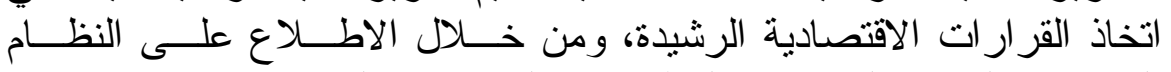

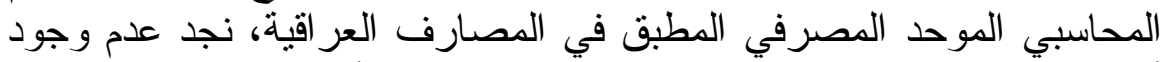

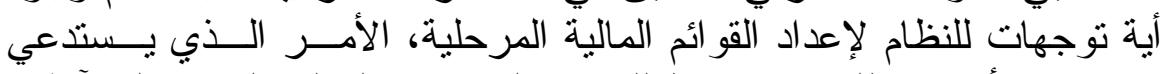

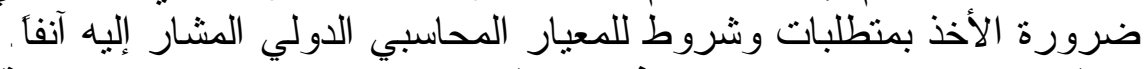

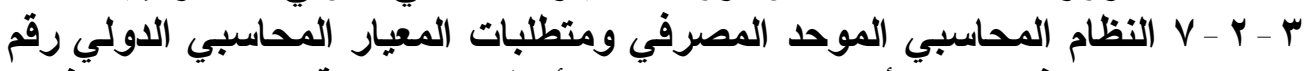

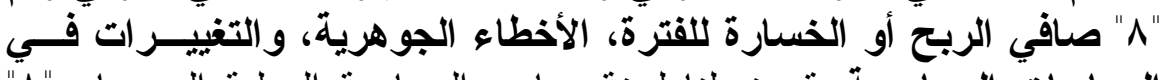

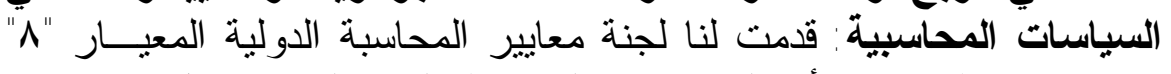

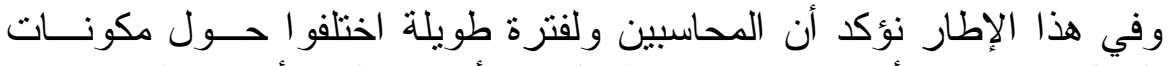

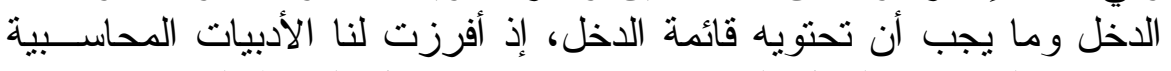

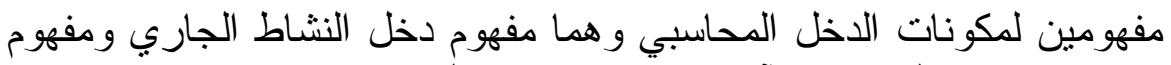

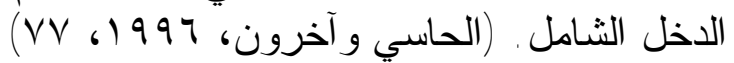
هذا ولقد استقر الرأي المحاسبي في المعايير الأمريكبة وتبعته في ذلاسك المعايير

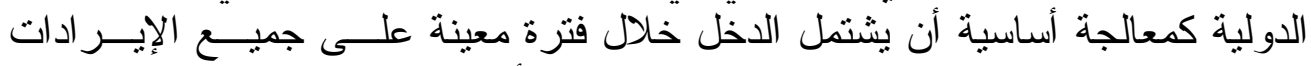

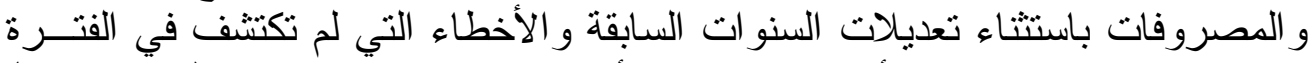
المالية نفسها الني تخصها، أما فيما يتعلق بالأرباح و الخسائر الاستثنائية (غير العادية) 
[rه人] أحد ومحمود

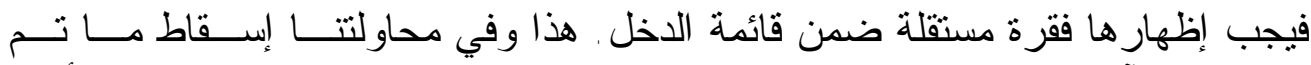

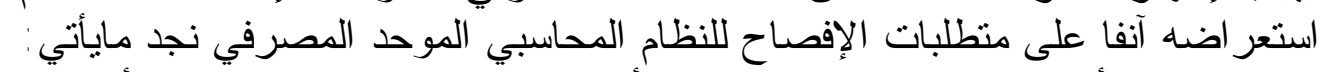

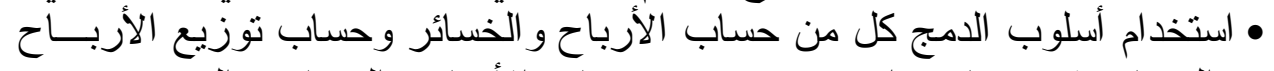

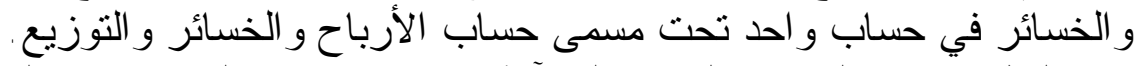

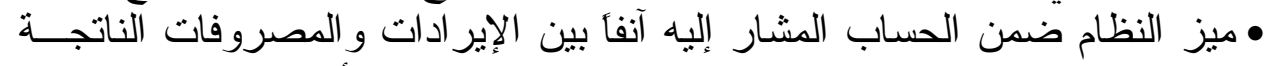

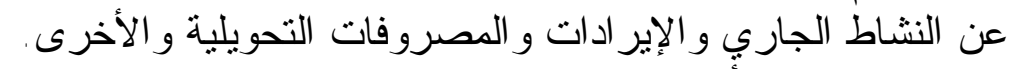

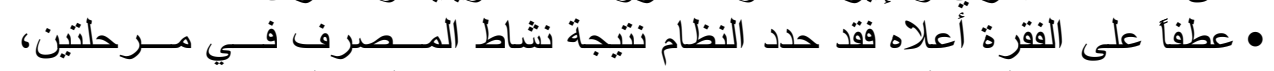

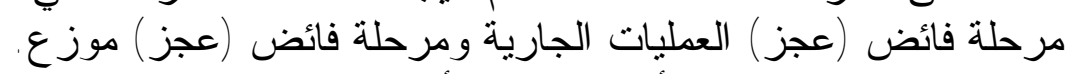

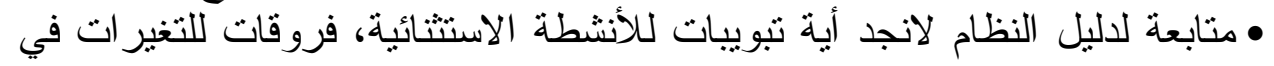

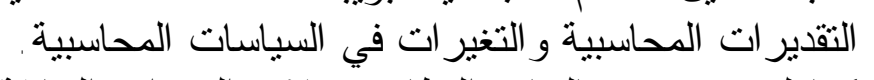

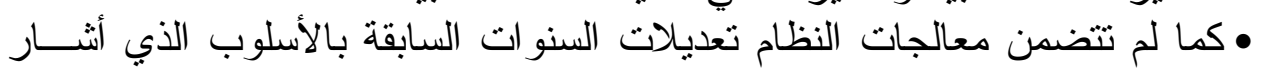

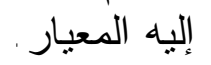

r - r - النظام المحاسبي الموحد المصرفي ومتطلبات المعيار المحاسبي الاولي رقم

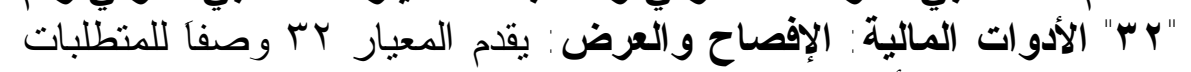

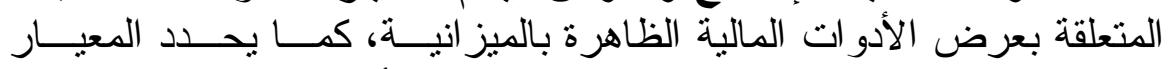

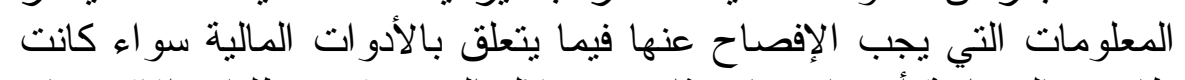

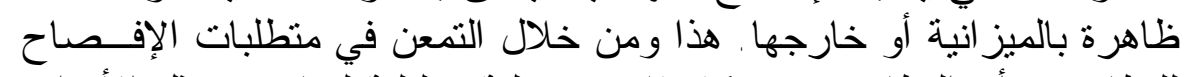

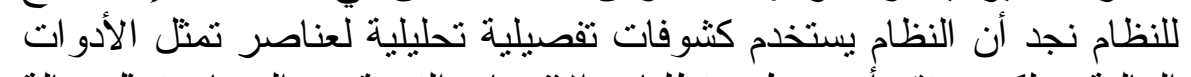

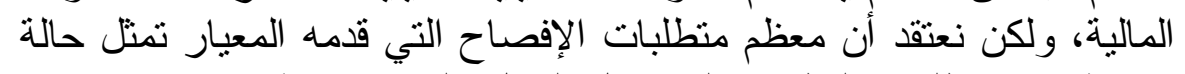

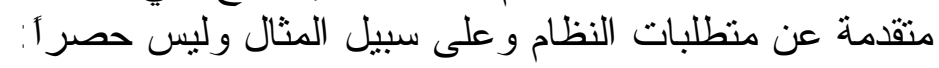

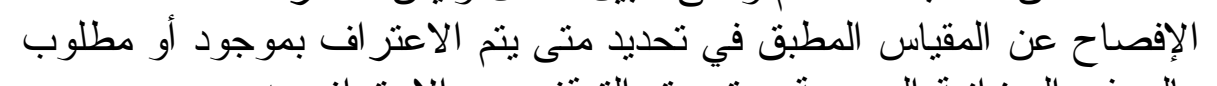

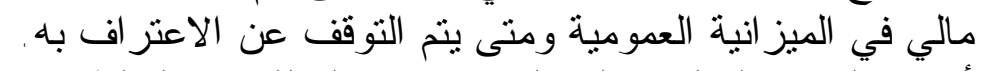

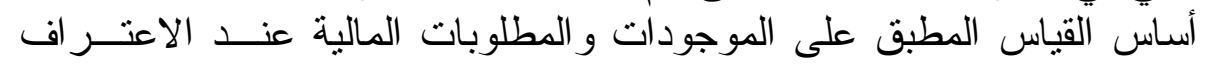

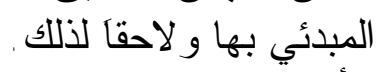

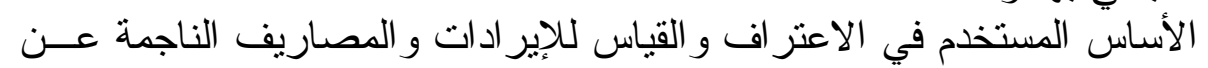
الموجودات و المطلوبات المالية.

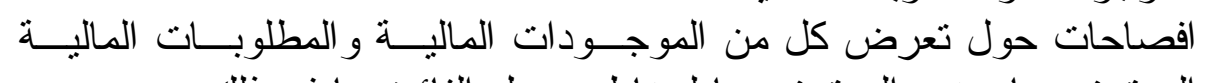

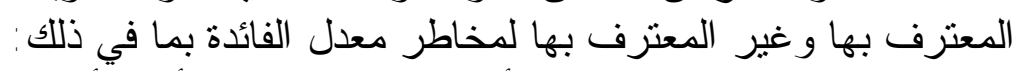

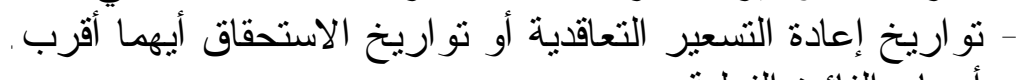
- أسعار الفائدة الفعلية.

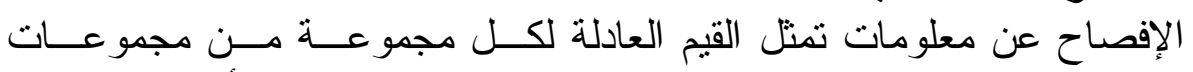

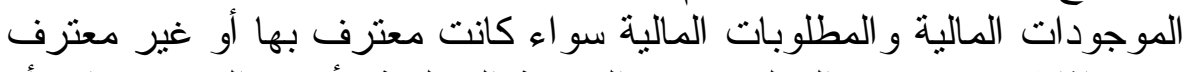

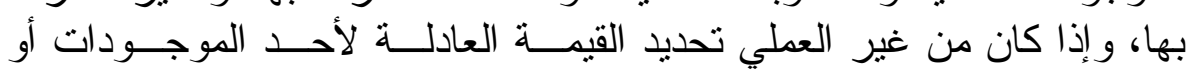




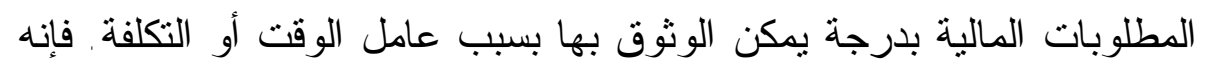

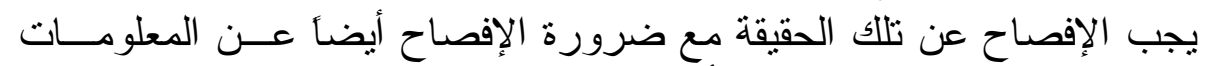

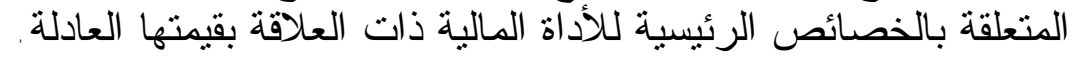

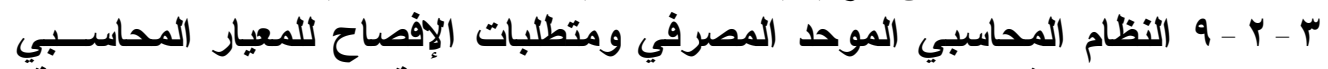

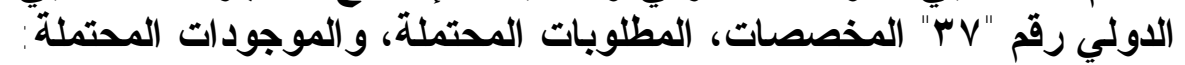

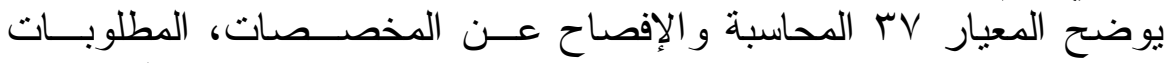

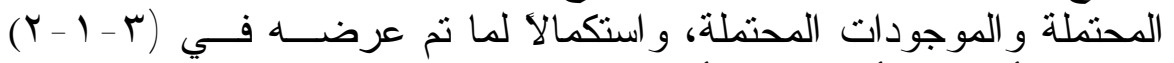

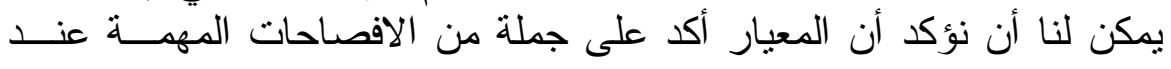

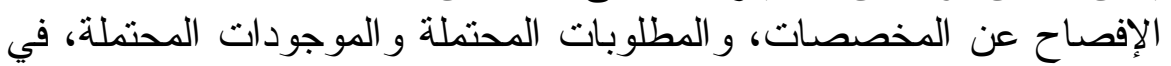

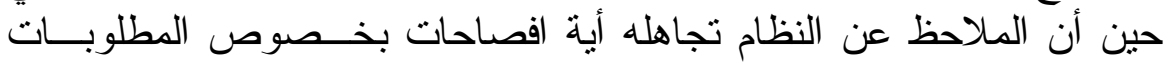
و الموجودات المحتملة. r - r - . 1 النظام المحاسبي الموحد المصرفي الموفي ومتطلبات المعيار المحاسبي الــدولي

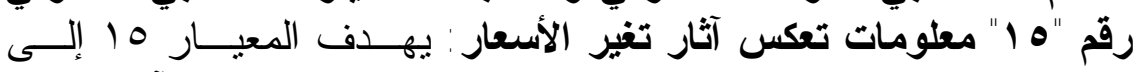

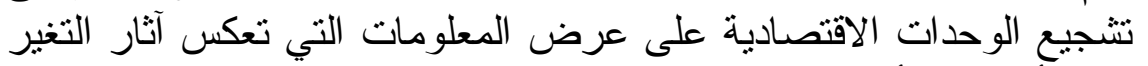

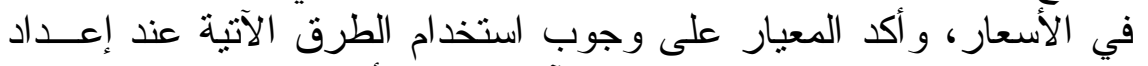

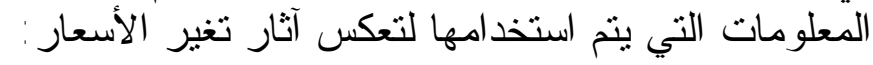
- التكلفة الحالية بدلا من التكلية التملفة التاريخية.

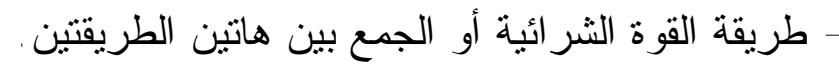

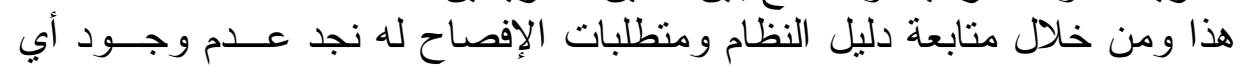

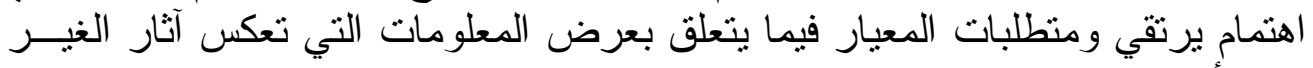

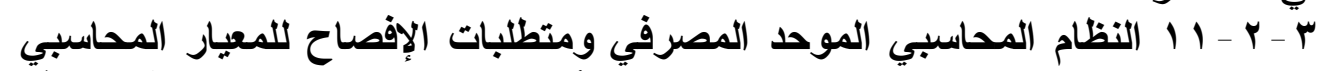

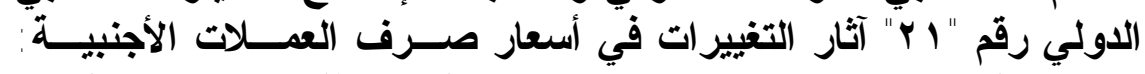

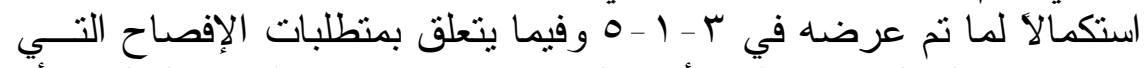

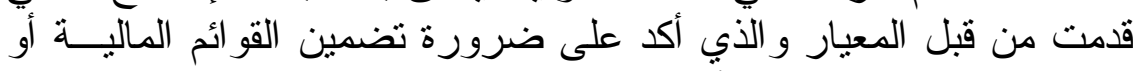

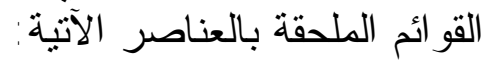

أ. مبلغ فروقات الصرف المشمولة في صافي الربح أو الخسارة للفترة.

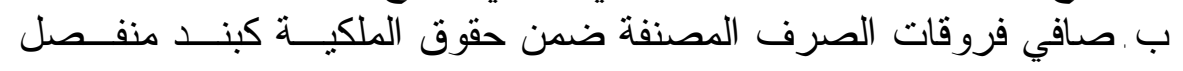
ومطابقة لمبلغ فروقات الصنات الصرف مابين بداية الفترة ونهايتها.

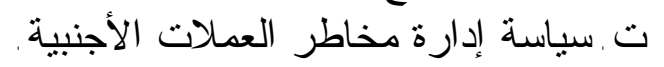

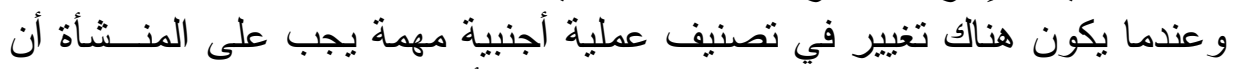

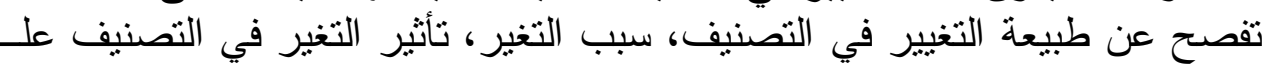

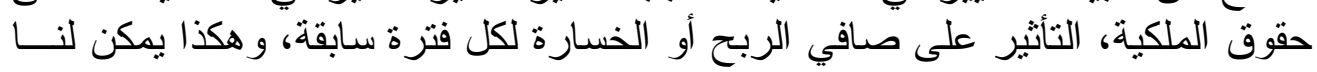


أحمد ومحمود [ [بr]

أن نؤكد هنا أيضاً أن النظام وفي إطار منطلبات الإفصاح لا يرتقـي إلــى منطلبــات

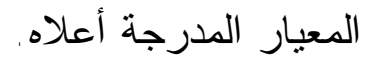

r r - r - r النظام المحاسبي الموحد المصرفي ومتطلبات الإفصاح للمعيار المحاسبي

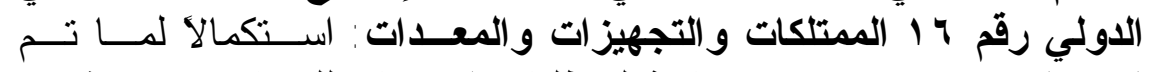

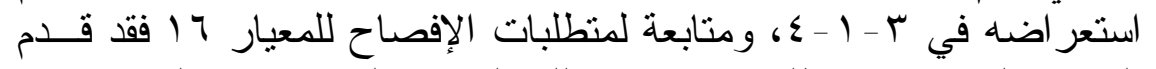

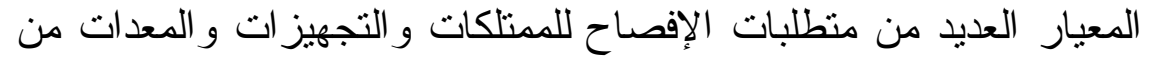
حيث:

- التسوية بين رصيد أول المدة ورصيد نهايــة المــدة مبينـــا: الإضـــافات

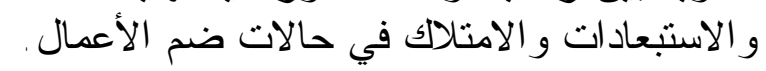
- القيمة الدفترية الإجمالية.

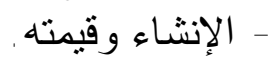
- وجود قيود على الإنى الملكية ومبالغه الغها.

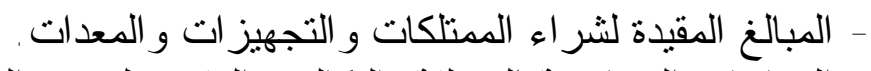

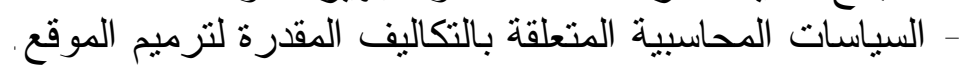

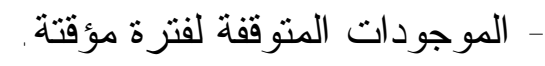
- الموجودات المعدة للبيع.

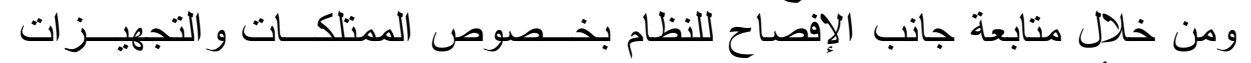

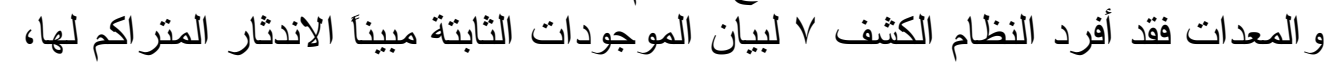

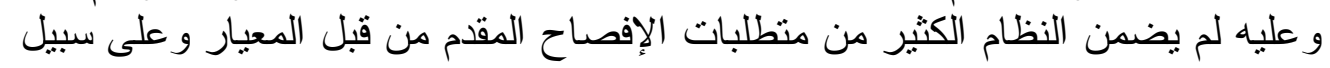

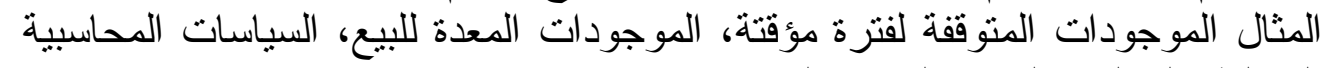

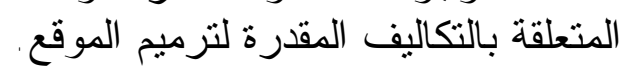

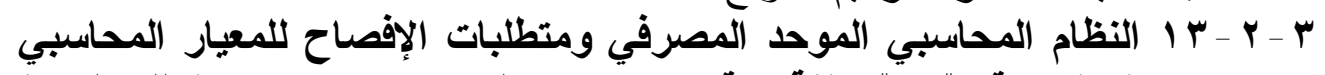

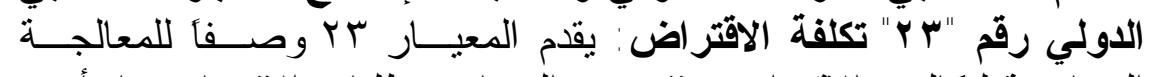

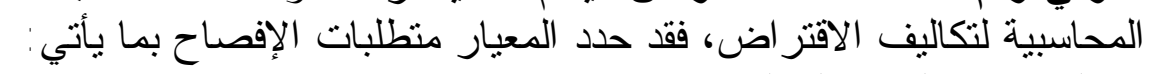

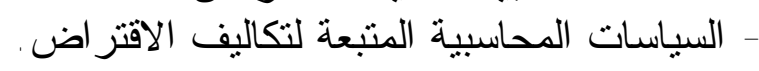

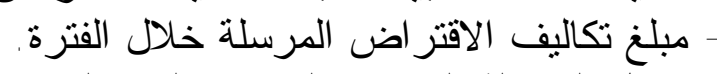

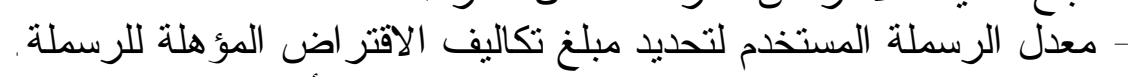

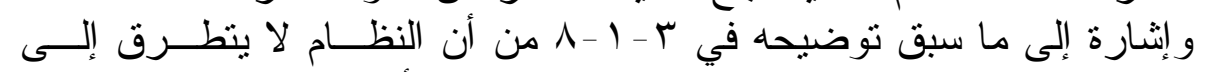

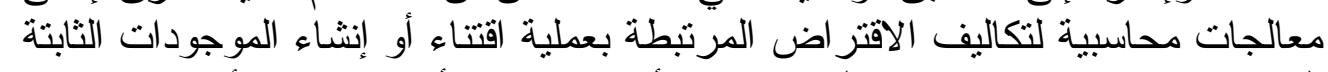

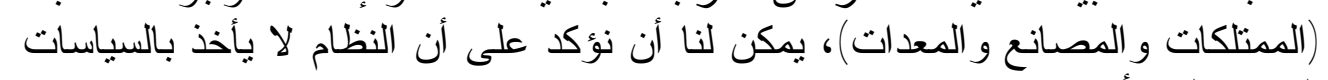

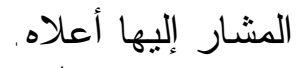

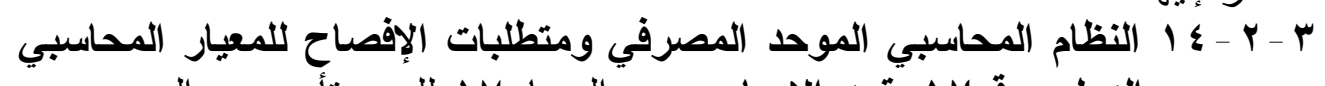

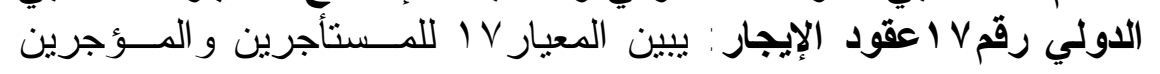


سياسات الافصاحات المحاسبية المناسبة لنطبيقها فيما يتعلق بعقود الإيجار

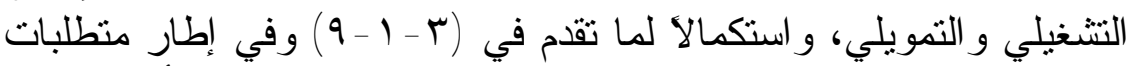

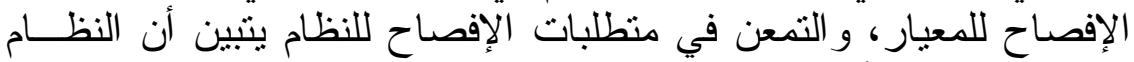

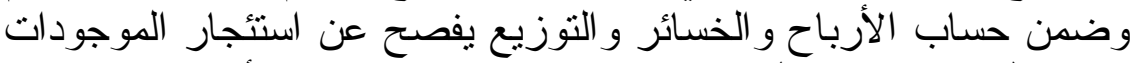

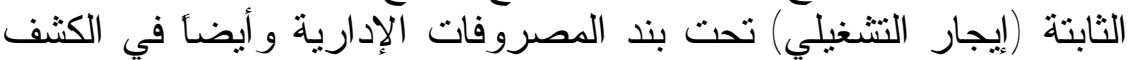

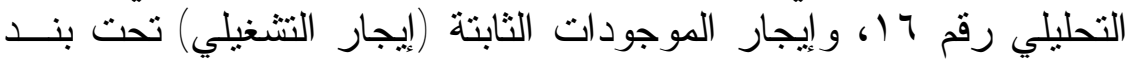

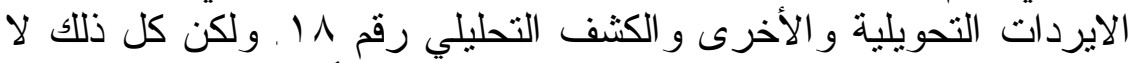

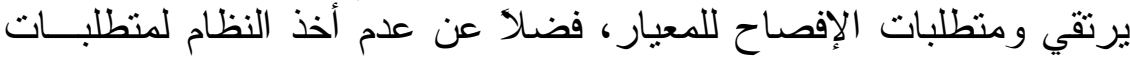

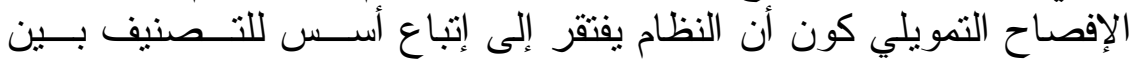
الإيجار التشغيلي و الإيجار التمويلي.

\section{الاستنتاجات و التوصيات}

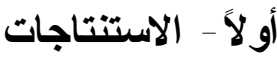

من خلال الدر اسة التحليلية التي قدمت يمكن لنا أن نستخلص الاستنتاجات الآتية:

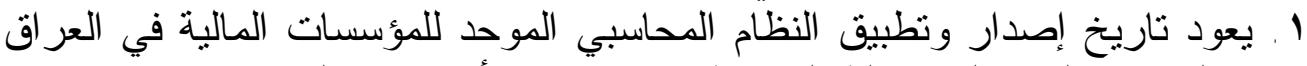

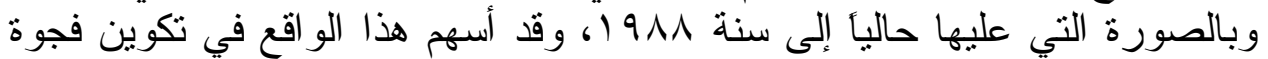

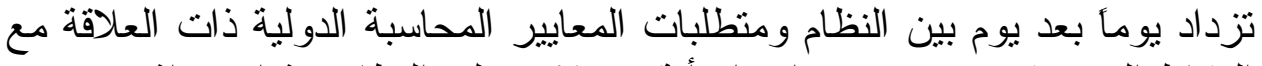

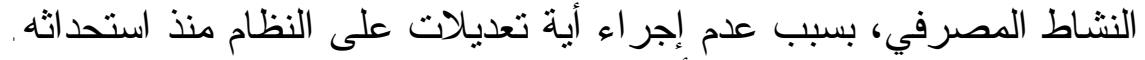

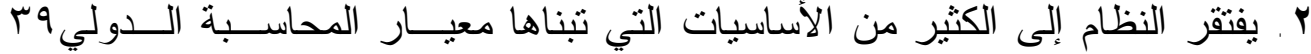

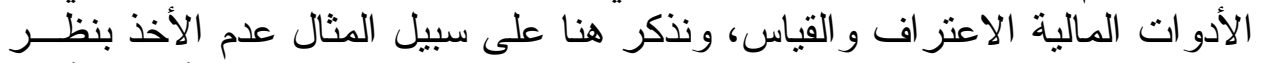

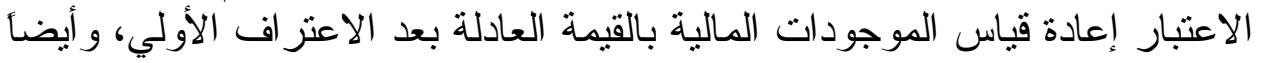

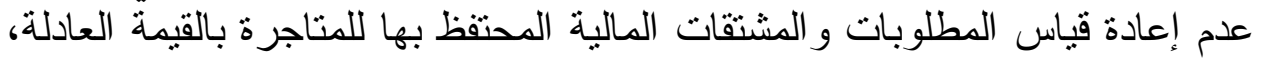

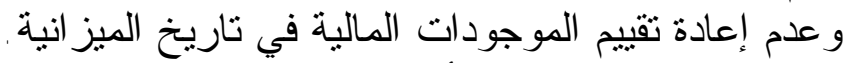

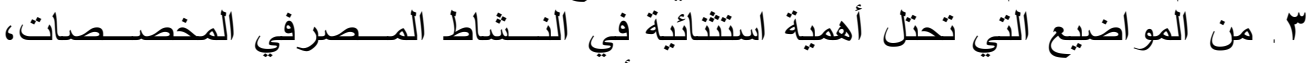

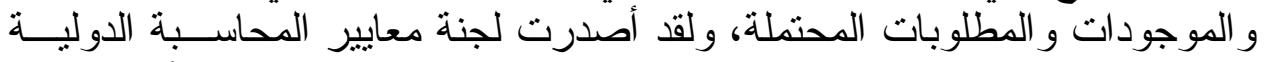

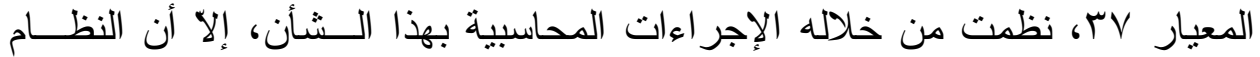

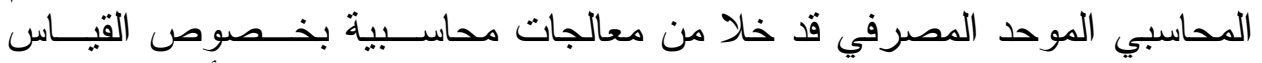

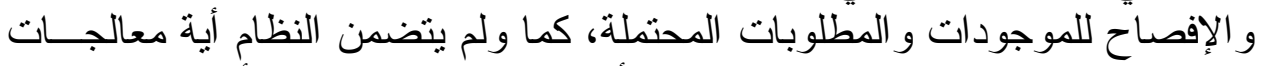

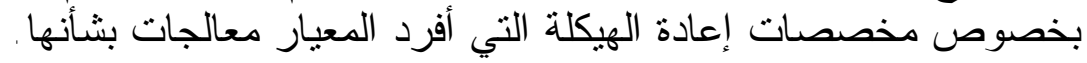

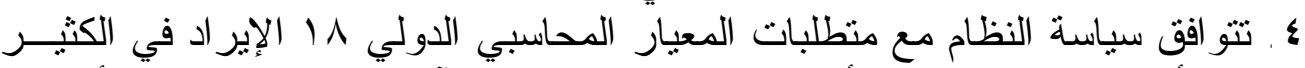

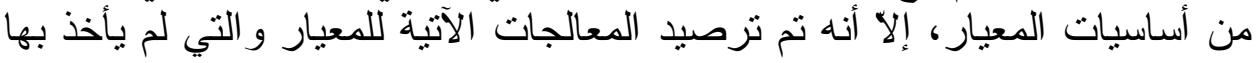
النظام: 


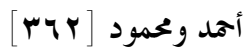

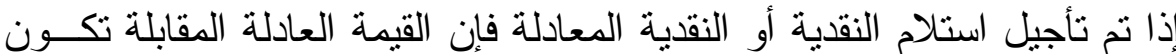
أقل من قيمته الاسمية المحددة، ويعامل الفرق بينة الفين القيمة الإسمية والقيمة العادلة بوصفها إير اد فو ائد. • في حالة احتفاظ الوحدة الاقتصادية بجزء غير مهم من العملية فإن عملية البيع

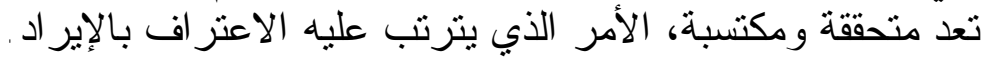

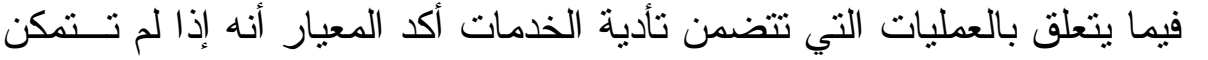

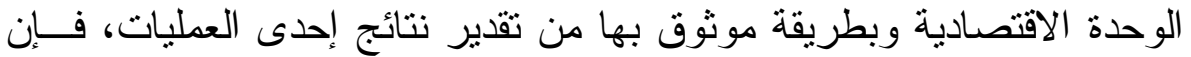

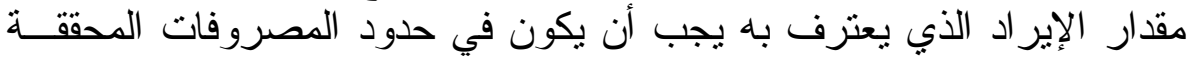

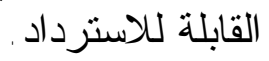

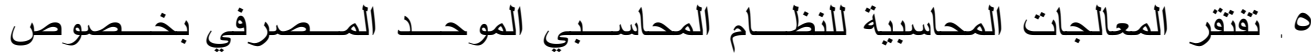

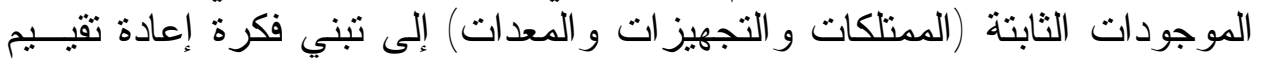

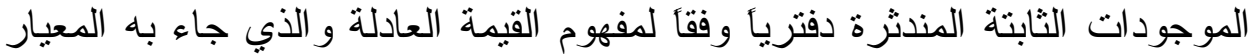

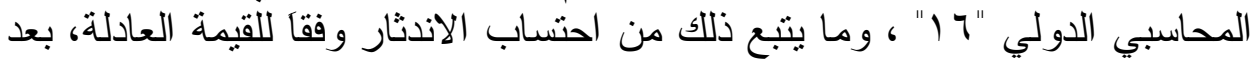

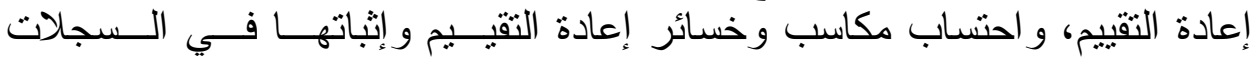
الدحاسبية، كما ويفتقر النظام للكثير من منطلبات الإفصاح المقدم من قبل المعيــار المذكور آنفأ.

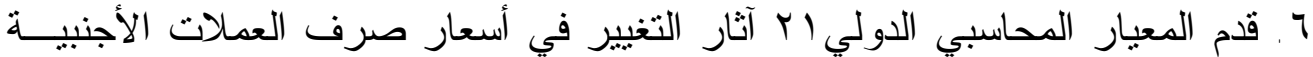

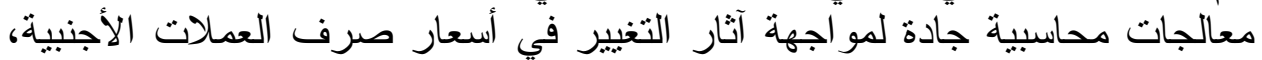

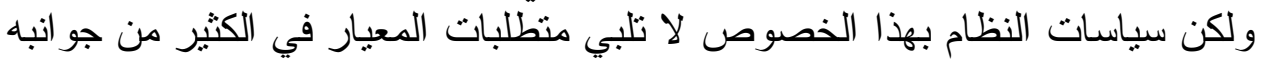
الأساسية. كما يمكن لنا أن نؤكد أيضاً أن النظام وفي إطار منطلبات النات هذا الإفصاح لا يرتقي ومتطلبات المعيار آنفأ.

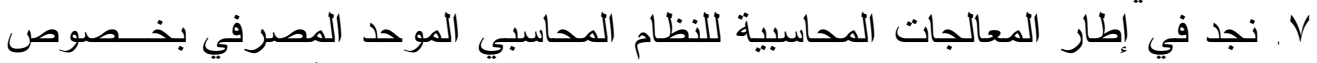

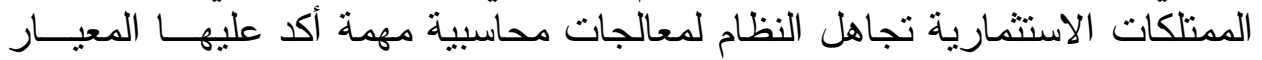

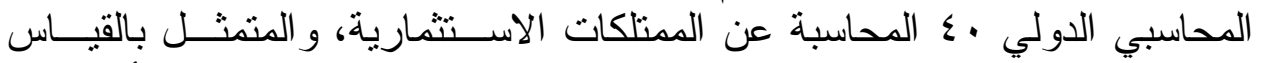

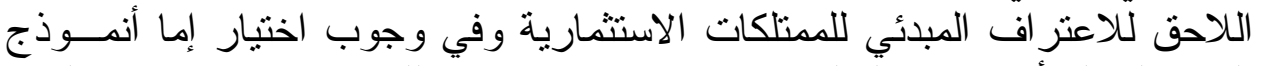

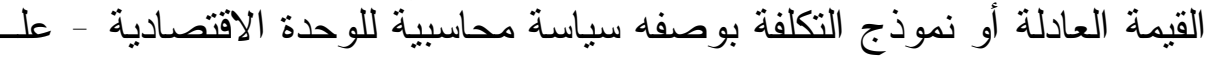

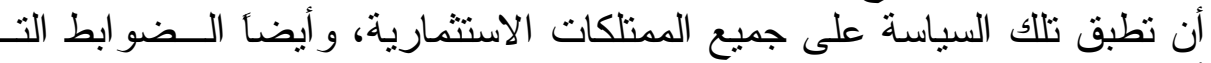

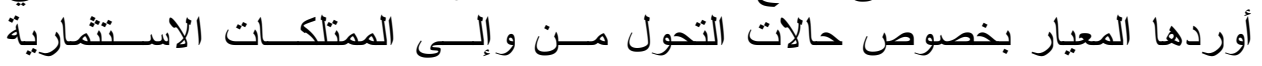

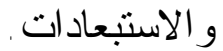

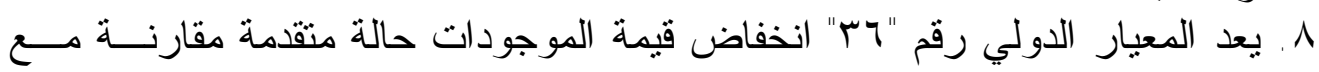

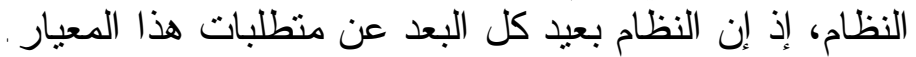

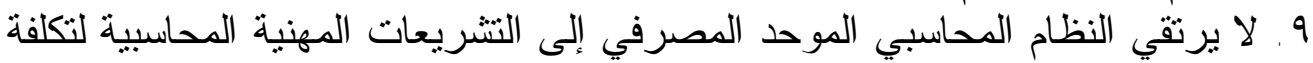
الاقتر اض ومنها المعيار المحاسبي الدولي رقم "بr با" تكلفة الاقتر اض و التي استقرت 


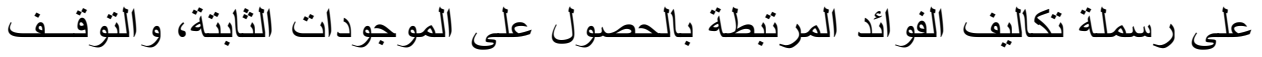

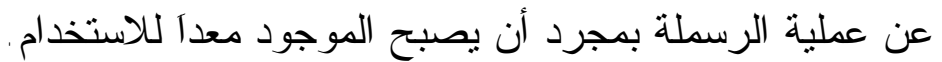

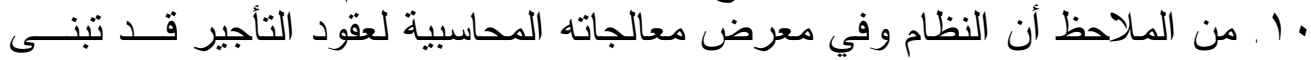

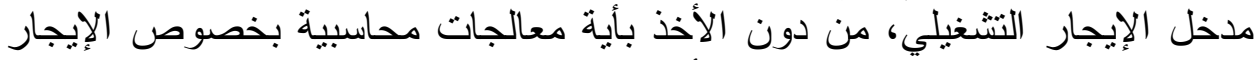

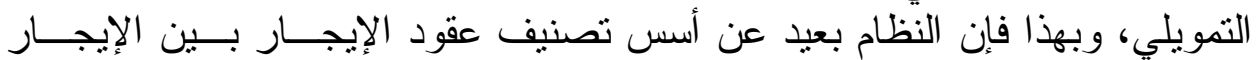

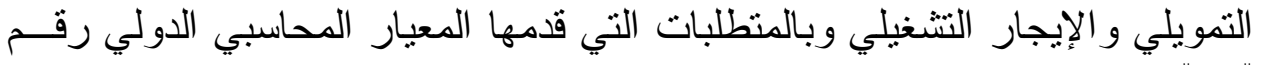

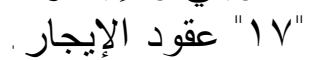

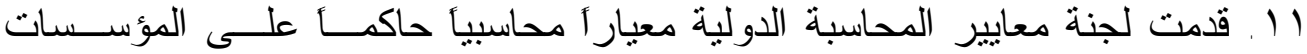

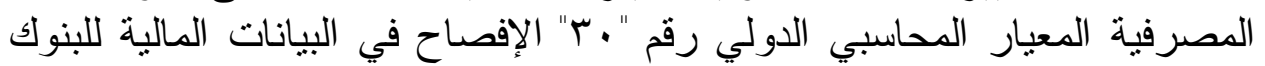

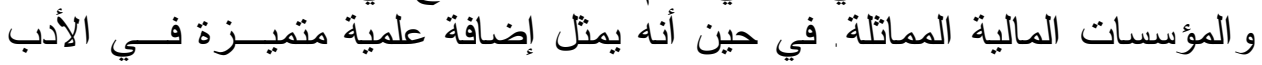

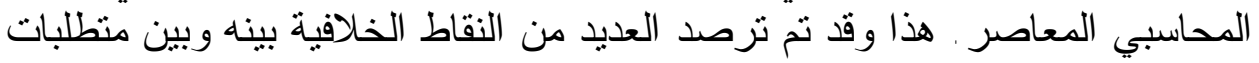

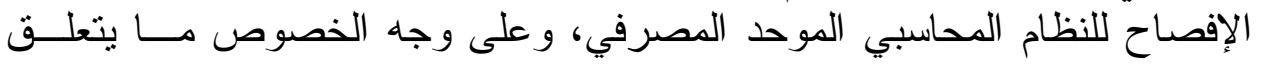

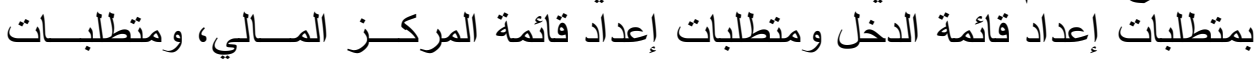

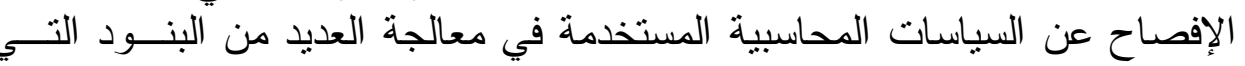

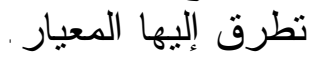

r ا ـ لم يأخذ النظام المحاسبي الموحد المصرفي بمتطلبات الإفصاح عن بيانات التدفق

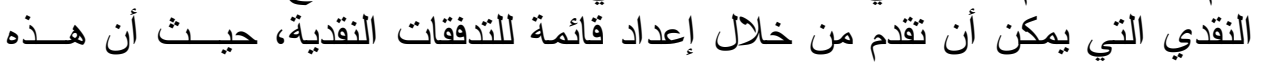
القاتمة أصبحت في الوني الوقت الحاضر من القو ائم المالية الأساسية.

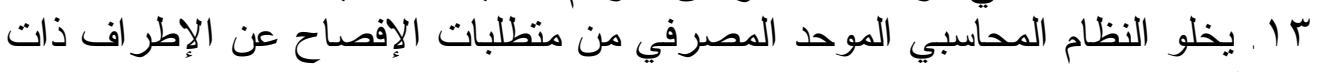
العلاقة. ع ا ـ عدم اهتمام النظام المحاسبي الموحد المصرفي بالسياسات المحاسبية للإفصاح عن

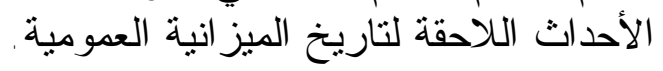

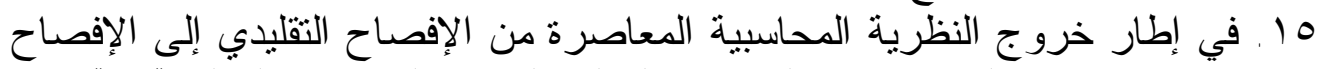

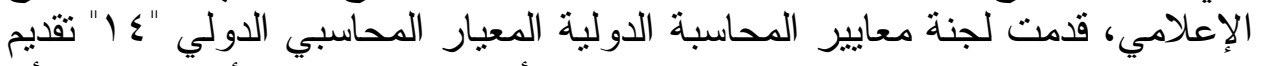

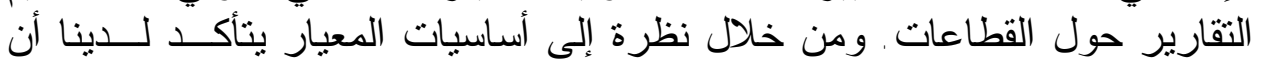

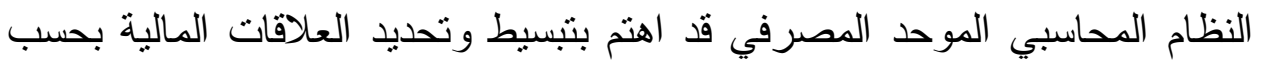

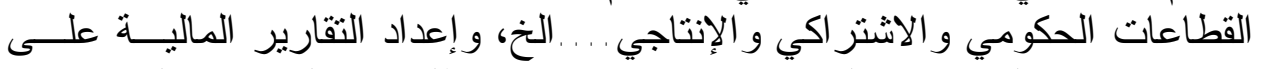

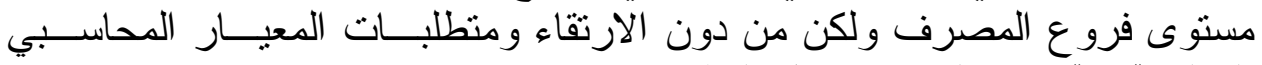

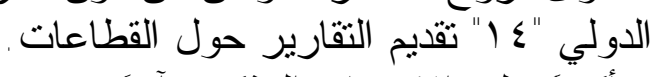

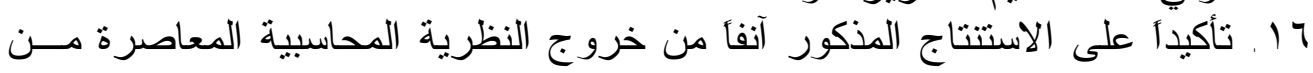

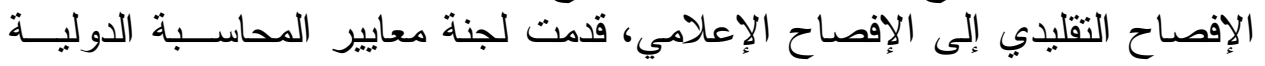

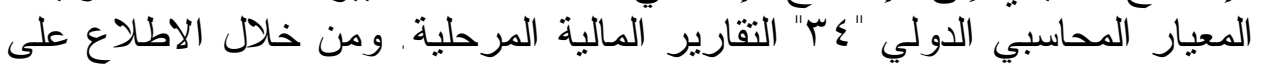


أحد ومحمود [؛ بTr]

منطلبات الإفصاح للنظام المحاسبي الموحد المصرفي نجد عدم وجود أية نوجهات للنظام لإعداد التقارير المالية المرحلية.

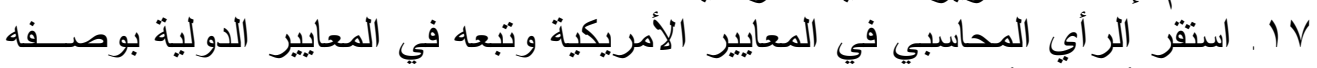

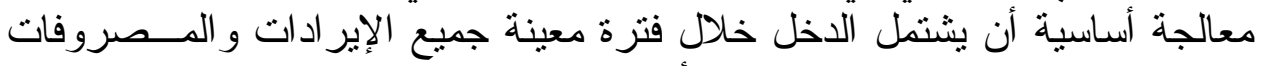

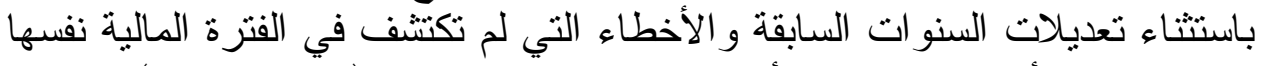

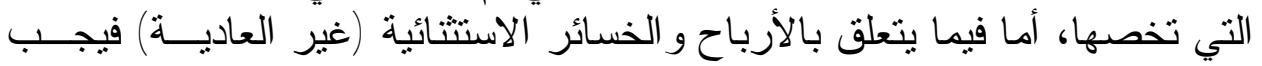

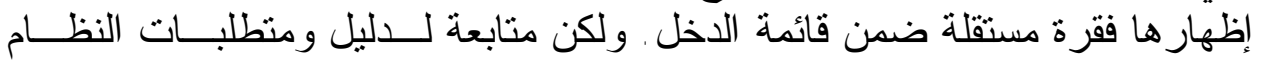

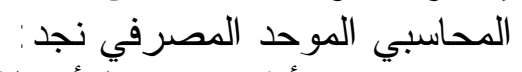

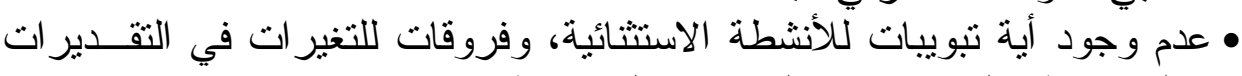

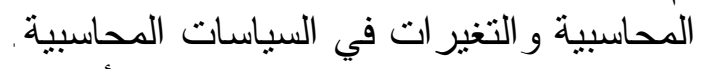
• • عدم معالجة تعديلات السنوات السابقة بالأسلوب الذي الذي أنثار إليه المعيار .

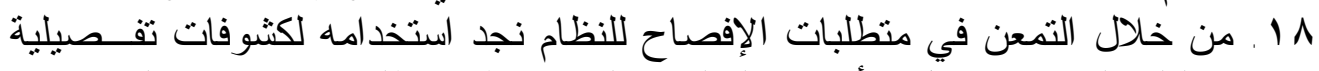

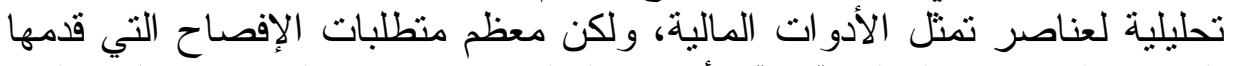

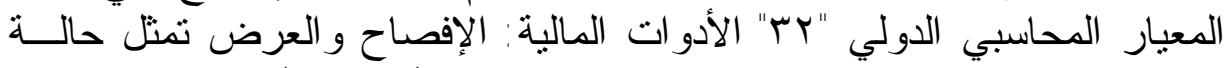

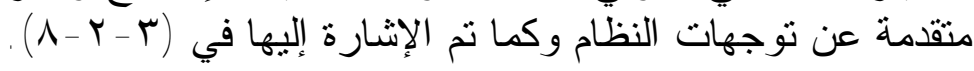

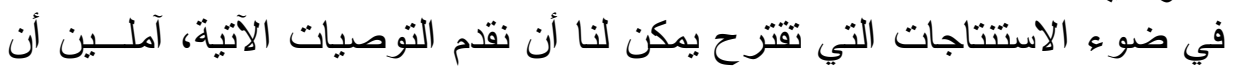

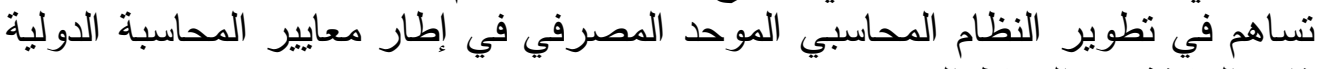

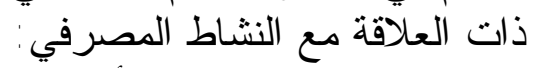

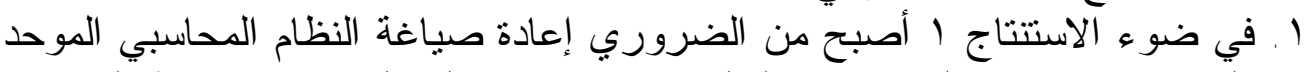

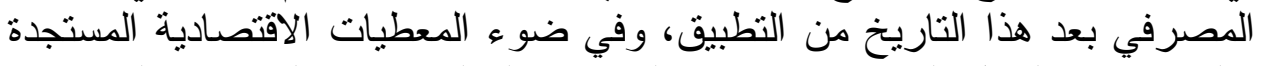

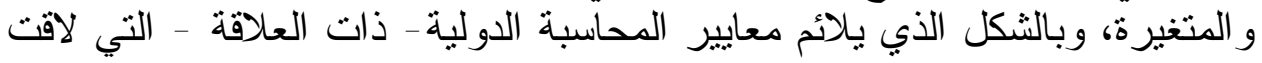

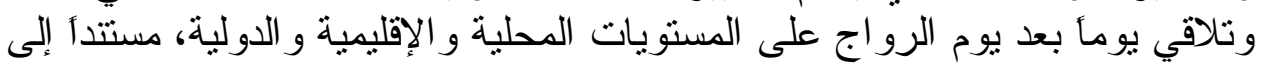

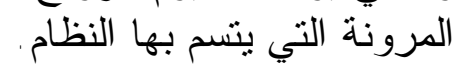

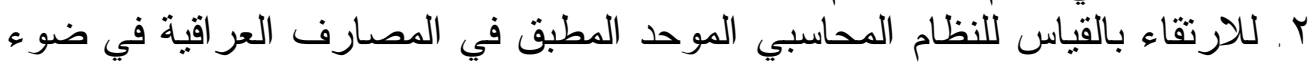

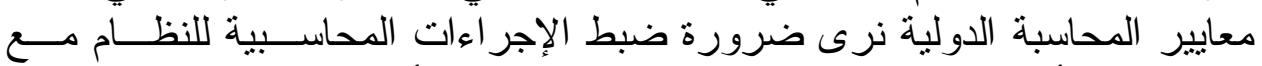

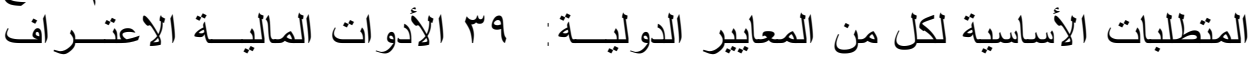

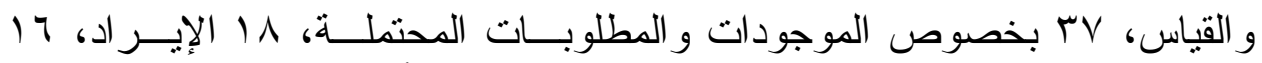

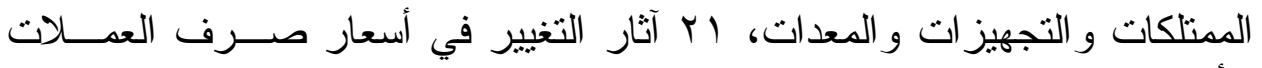

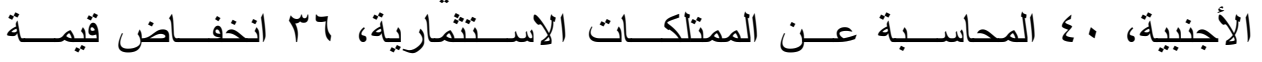

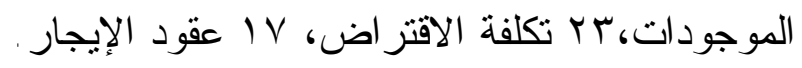




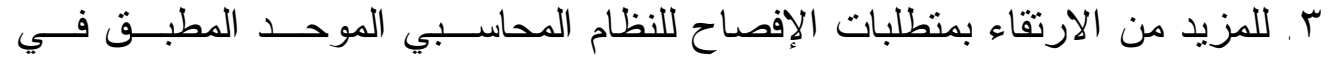

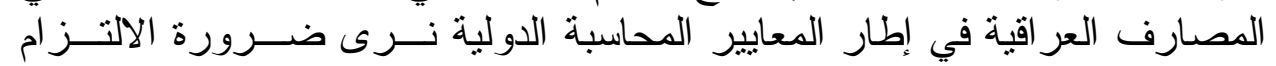

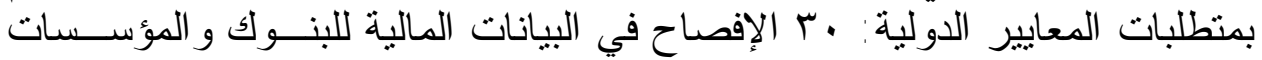

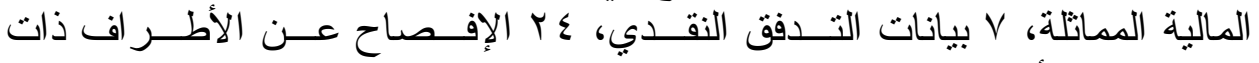

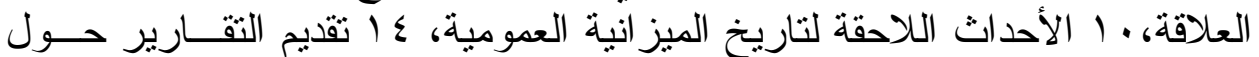

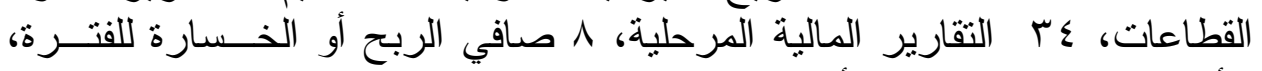

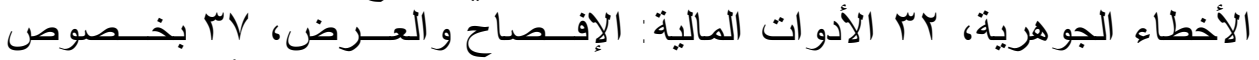

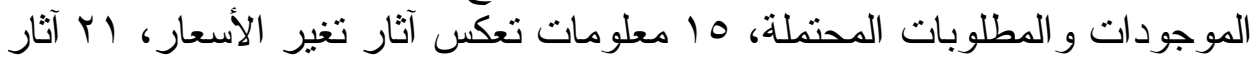

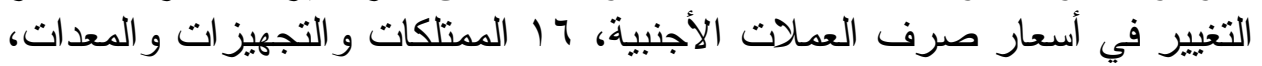

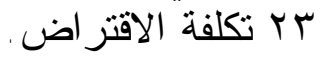

\section{المراجع أولاً - المر اجع باللغة العربية}

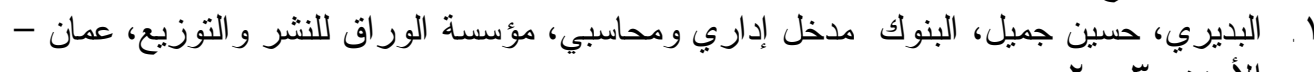

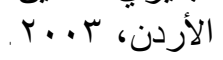

r. . الجزر اوي، إبر اهيم محمد علي طاهر، و آخرون، المحاسبة في النشاط المــصرفي، بغــداد، طا، r. الحاسي، جمعة خليفة، وآخرون، المحاسبة المتوسطة، دار النهضة للطباعة و النــشر، بيــروت، الجئ

ع. . الغبان، ثائر صبري محمود و الغبان، فائزة إبر اهيم محمود، النظم المحاسبية المتخصصة، جامعة

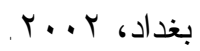
○. جعفر ، عبدالاله نعمة، محاسبة التكاليف في البنوك التجارية، دار الثروق للنشر و التوزيع، عمان،

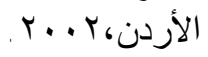

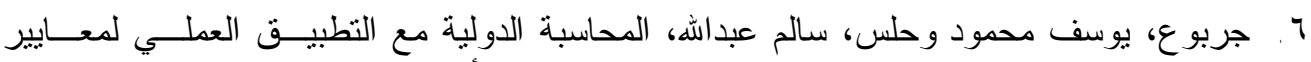

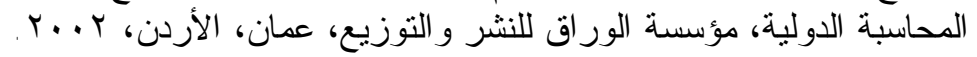

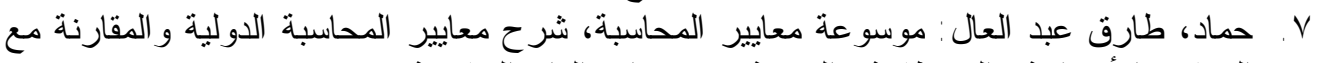

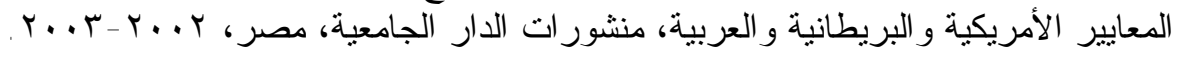

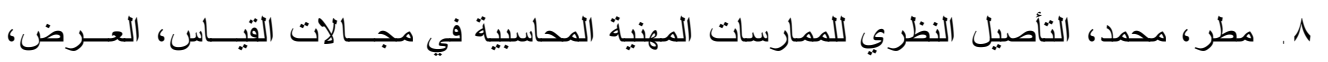

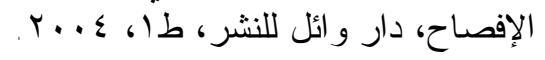

9. ـ ميرزا، عباس علي، والخار وآخرون، المعايير الدولية لإعداد التقارير المالية، المطابع المركزية، عمان،

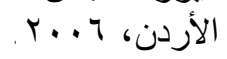

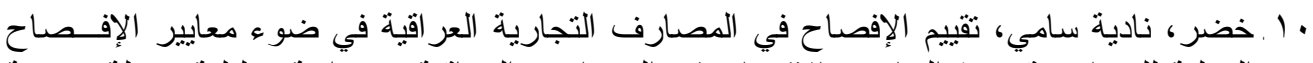

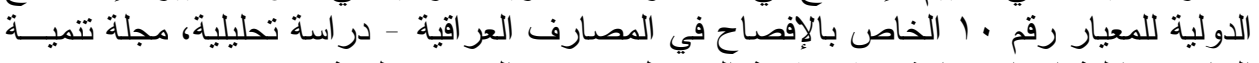

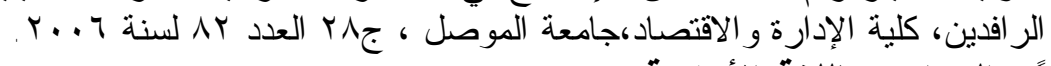

ثانياً - المر اجع باللغة الأجنبية

- International Financial Reporting Standard (IFRSs) - 2004. 